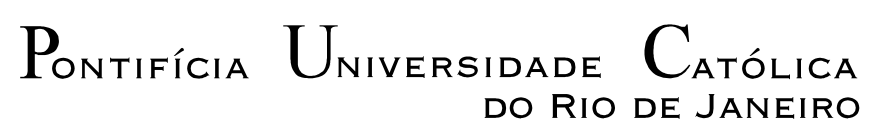

Guilherme Madeira Martins

\title{
RUÍDO TOTAL: Analogia e interpretação extensiva
}

TESE DE DOUTORADO

DePARTAMENTo DE DiReito
Programa de Pós-Graduação em Direito

Rio de Janeiro, Dezembro de 2020. 

$\operatorname{Pontifícia~}_{\text {Do Rio de Janeiro }}$

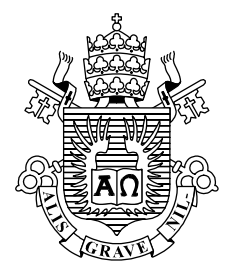

Guilherme Madeira Martins

Ruído Total: analogia e interpretação extensiva

Tese de Doutorado

Tese apresentada ao programa de Pós-Graduação em Teoria do Estado e Direito Constitucional da PUC-Rio como requisito parcial para obtenção do grau de Doutor em Direito.

Orientador: Noel Struchiner 
Pontifícia Universidade $_{\text {do Rio de Janeiro }}$ Cálica $_{\text {danta }}$

Guilherme Madeira Martins

Ruído Total: analogia e interpretação extensiva

Tese de Doutorado

Tese apresentada ao programa de Pós-Graduação em Teoria do Estado e Direito Constitucional da PUC-Rio como requisito parcial para obtenção do grau de Doutor em Direito. Aprovada pela comissão abaixo assinada.

Prof. Orientador: Dr. Noel Struchiner

Departamento de Direito da PUC-Rio

Prof. Dr. Adrian Sgarbi

Departamento de Direito da PUC-Rio

Prof. Dr. Fernando Galvão de Andréa Ferreira

Departamento de Direito da PUC-Rio

Prof. Dr. Lucas Miotto Lopes

Departamento de Direito da Universidade de Maastricht

Prof. Dr. Sergio Nojiri Departamento de Direito da USP

Rio de Janeiro

21 de dezembro de 2020 
Todos os direitos reservados. É proibida a reprodução total ou parcial do trabalho sem autorização da universidade, do autor e do orientador.

\section{Guilherme Madeira Martins}

Graduado em Direito pela Faculdade Metodista Granbery, Juiz de Fora - MG. Mestre em Teoria do Estado e Direito Constitucional pela Pontifícia Universidade Católica do Rio de Janeiro, PUC/RJ. É professor de teoria do direito, filosofia jurídica e direito constitucional em cursos de graduação e pós-graduação.

Ficha Catalográfica

Martins, Guilherme Madeira

Ruído total: analogia e interpretação extensiva / Guilherme Madeira Martins ; orientador: Noel Struchiner. - 2020.

182 f. ; $30 \mathrm{~cm}$

Tese (doutorado) - Pontifícia Universidade Católica do Rio de Janeiro, Departamento de Direito, 2020.

Inclui bibliografia

1. Direito - Teses. 2. Teoria do direito. 3. Interpretação extensiva. 4. Analogia. 5. Raciocínio analógico. 6. Argumentos analógicos. 7. Lacunas jurídicas. 8. Textura aberta da linguagem. I. Struchiner, Noel. II. Pontifícia Universidade Católica do Rio de Janeiro. Departamento de Direito. III. Título.

CDD: 340 


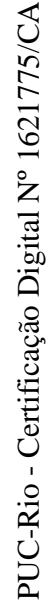

Para Marcela, sempre e para sempre. 


\section{Agradecimentos}

Ao professor, orientador e mentor Noel Struchiner, por todas as orientações referentes a este trabalho; e pelo auxílio, amizade e confiança nestes quase dez anos.

Aos professores Adrian Sgarbi, Alejandro Bugallo Alvarez, Carlos Frederico Delage Junqueira de Oliveira e Nilton Rodrigues de Oliveira, que me fizeram amar a teoria do direito.

Às coordenadoras Pamella Carolina de Souza Pacheco Carvalho, Laira Carone Rachid e Isaura Barbosa de Oliveira Lanza, por toda a ajuda profissional durante o período do doutorado.

Ao amigo Gabriel Senra e Pádua, pela ideia que acabou virando o problema deste trabalho.

Aos meus sócios na editora Varanda, Deco Porteira, Laís Cerqueira e Ulisses Belleigoli, que seguraram o rojão durante a minha ausência.

Ao Anderson e à Carmen, pelos inúmeros auxílios nos últimos quatro anos, sempre com a maior gentileza.

À PUC-Rio e à Capes, pelos auxílios concedidos, sem os quais este trabalho não poderia ter sido realizado.

À minha querida família, pelo constante apoio e amor.

Finalmente, à Marcela, minha colega, amiga, esposa, horizonte, motivo e vida - de janeiro a janeiro, até o mundo acabar. 


\section{RESUMO}

MARTINS, Guilherme Madeira. STRUCHINER, Noel (orientador). Ruído total: analogia e interpretação extensiva. Rio de Janeiro, 2020, 208p. Tese de Doutorado - Departamento de Direito, Pontifícia Universidade Católica do Rio de Janeiro.

A presente tese é primordialmente um trabalho de teoria do direito cujo objeto de pesquisa é a relação entre duas estratégias que o jurista pode utilizar para solucionar problemas de ausência e/ou insuficiência normativa: a analogia e a interpretação extensiva. A doutrina brasileira é unânime ao compreender que, apesar da proximidade, a analogia e a interpretação extensiva são estratégias distintas. O objetivo da presente tese é questionar essa unanimidade; para tanto, busca aprofundar o estudo dessas estratégias e investigar a relação existente entre elas. Apesar da diferença conceitual existente e da distinção presente no âmbito do direito penal - que admite a utilização da interpretação extensiva, mas não a analogia (exceto para benefício do réu) -, a linha limítrofe que demarca o âmbito de aplicação de ambas é fluída e de aplicação prática. Os estudos sobre essas estratégias acabam priorizando as diferenças, negligenciando a proximidade existente entre elas. A hipótese da tese: a chave para a compreensão da relação entre analogia e interpretação extensiva reside naquilo que elas têm em comum. Essa proximidade é evidenciada com o apoio das recentes descobertas no campo das ciências cognitivas, em especial nos estudos sobre o raciocínio analógico.

\section{Palavras-chave}

Teoria do direito; interpretação extensiva; analogia; raciocínio analógico; argumentos analógicos; lacunas jurídicas; textura aberta da linguagem. 


\section{ABSTRACT}

MARTINS, Guilherme Madeira. STRUCHINER, Noel (advisor). Total noise: analogy and extensiva interpretation. Rio de Janeiro, 2020, 208p. Doctoral Thesis - Departamento de Direito, Pontifícia Universidade Católica do Rio de Janeiro.

The presente thesis is primarily a work of jurisprudence whose object of research is the relationship between two strategies that the lawyer can use to solve problem of regulatory absence and/or insufficiency: analogy and extensive interpretation. Brazilian doctrine is unanimous in understanding that, despite the proximity, analogy and extensive interpretation are distinct strategies. The purpose of this thesis is to question this unanimity; therefore, it seeks to deepen the study of these strategies and investigate the relationship between them. Despite the existing conceptual difference and the distinction presente in the scope of criminal law - which admits the use of extensive interpretation, but not the analogy (except fot the benefit of the defendant) -, the boundary line that marks the scope of both is fluid and whit difficult practical application. Studies on these strategies end up prioritizing differences, neglecting the existing proximity between them. The thesis hypothesis: the key to understanding the relationship betweem analogy and extensive interpretation lies in what they have in common. This proximity is evidenced with the support of recente discoveries in the field of cognitive sciences, especially in studies on analogical reasoning.

\section{Keywords}

Jurisprudence; extensive interpretation; analogy; analogical reasoning; analogical arguments; legal gaps; open texture. 


\section{SUMÁRIO}

1. Introdução: ruído total

2. Um conto de duas cidades: analogia e interpretação extensiva

2.1. Analogia

2.2. Interpretação extensiva

2.3. Analogia e interpretação extensiva lado a lado

3. Dois caminhos, mesmo destino: a tensão entre analogia e

3.1. Traços distintos e comuns

3.2. Os veículos no parque

3.3. O mesmo resultado

4. Uma casa, dois endereços: analogia e interpretação extensiva frente ao princípio da legalidade

4.1. O princípio da legalidade

4.2. Os mesmos traços distintos...

4.3. ... e comuns

5. Entre a dedução e a indução: a estrutura do argumento analógico

5.1. Um começo 
5.4. O contra-ataque da visão tradicional - e a defesa dos argumentos analógicos dedutivos

5.5. De volta ao universo jurídico

6. Ruído de fundo: a contribuição das ciências cognitivas para a compreensão do raciocínio analógico

6.1. Manipulados por uma analogia

6.2. Somos realmente tão superficiais?

6.3. O combustível e o fogo da cognição

6.4. Analogia e linguagem

7. O resto é ruído: analogia e interpretação extensiva em lide

7.1. O caso "Rádio do Vaticano"

7.2. Uso estratégico na Ação Direta de Inconstitucionalidade por Omissão 26 e no Mandado de Injunção 4733

8. Conclusão: silêncio? 


\section{LISTA DE FIGURAS}

Figura 1 - Esquema da vagueza 
"Não importa onde estejamos, a maior parte do que ouvimos é ruído. Quando ignoramos, nos perturba. Quando o escutamos com atenção, ficamos fascinados." (John Cage, Silence) 


\section{Introdução: ruído total}

Se, como escreveu Aristóteles (1969, p. 40), a perplexidade é o pontapé para a busca do conhecimento, o espanto responsável por acender a faísca que deu início a essa pesquisa aconteceu quando um colega professor de direito penal disse, na sala dos professores durante o intervalo entre as aulas, que "até hoje o direito penal brasileiro não consegue explicar a diferença entre a analogia e a interpretação extensiva".

O motivo do espanto se deu em razão da uniformidade que nos deparamos nos manuais de teoria do direito e direito penal escritos pelos juristas brasileiros: todos afirmam que, apesar da proximidade, a analogia e a interpretação extensiva são técnicas distintas e que não se confundem. E mais: a doutrina brasileira é unânime não somente no sentido de afirmar a diferença entre elas, mas também na exposição das razões que a justificam: a analogia é uma técnica de integração do ordenamento jurídico que atribui a um caso não regulamentado pelo direito a mesma disciplina conferida a um caso semelhante já regulamentado, enquanto a interpretação extensiva é uma operação interpretativa que expande o campo semântico das disposições legais nos casos em que a lei disse menos do que queria dizer (lex minus dixit quam voluit).

Diante de tal uniformidade, os sentimentos experienciados pelo leitor são sentimentos raros em um campo do conhecimento com divergências teóricas tão profundas como o direito: segurança e certeza. 
Mas o espanto é um sentimento persistente, e aliado da curiosidade. Se a doutrina brasileira é unânime, porque "o direito penal brasileiro não consegue explicar a diferença entre analogia e interpretação extensiva"?

O espanto leva à curiosidade; a curiosidade, à pesquisa; e, dessa pesquisa, um ruído começa a se fazer ouvir: talvez a distinção entre analogia e interpretação extensiva não seja tão indiscutível assim.

A presente tese narra a progressão desse ruído, que começa baixo, quase inaudível, mas que termina como um ruído total, impossível de ser ignorado.

O termo "ruído total" foi cunhado pelo escritor David Foster Wallace no ensaio "Deciderization 2007 - Special Report". Nesse ensaio, Wallace tenta retratar um tipo de ansiedade comum à cultura atual. Ela decorre da vontade por estar sempre informado ao mesmo tempo em que há uma sensação permanente de afogamento diante do tsunami de informações disponíveis. Aquele que quer estar informado se vê diante de inúmeras possibilidades de acesso à informação que o bombardeiam com diferentes dados, fatos, contextos e perspectivas. É paradoxal: quanto mais informação adquirimos, maior é o sentimento de insegurança mesmo nos casos em que parece haver uniformidade no que é informado. A realidade é "esmagadoramente enorme e complexa" (WALLACE, 2013, p. 303). Os sentimentos de segurança e certeza são aparentes.

Como no caso da distinção entre analogia e interpretação extensiva. Em um primeiro momento, todas as informações disponíveis parecem apontar para um consenso; mas, quando todas essas informações são postas lado a lado, quando todas as justificadas são analisadas, começam a surgir algumas incongruências. $O$ consenso parece mais confundir do que elucidar.

Chama a atenção, por exemplo, o fato de vários juristas citarem a proximidade entre a analogia e a interpretação extensiva: são técnicas próximas, porém distintas. Mas em que consiste essa proximidade? Essa é uma pergunta que fica sem resposta. Talvez a resposta seja auto evidente, de desnecessária explicação; ou talvez não - talvez essa proximidade ainda precise ser desenvolvida pela teoria do direito. Chama a atenção, por exemplo, os diferentes termos utilizados pelos juristas 
quando se referem à analogia e à interpretação extensiva (como "extensão analógica", "aplicação analógica", "interpretação por analogia"), deixando o leitor na dúvida sobre qual técnica o autor está se referindo sendo o exemplo mais paradigmático dessa confusão o termo "interpretação extensiva por analogia" (DINIZ, 1996, p. 89). Chama a atenção, por exemplo, o fato de vários juristas alertarem o leitor para que ele não confunda a analogia e a interpretação extensiva. Ora, se a distinção entre ambas as técnicas é tão simples, qual a razão dos constantes alertas? Uma resposta possível: a distinção entre ambas as técnicas só parece ser simples.

Diante da uniformidade que encontramos na literatura jurídica brasileira, o jurista brasileiro pode estranhar quando Riccardo Guastini afirma que "na teoria do direito, se discute incansavelmente se a analogia se diferencia ou não da interpretação extensiva" (2014, p. 274). Mas a verdade é que, fora do Brasil, existem vários juristas que se questionam exatamente isso. O jurista alemão Karl Engisch, por exemplo, afirma que "a linha limítrofe entre a interpretação (especialmente a interpretação extensiva), por um lado, e a analogia, pelo outro, é fluida" (1996, p. 294); os argentinos Carlos Eduardo Alchourrón e Eugenio Bulygin suspeitam que essa distinção "pode ser facilmente desvirtuada" (2015, p. 199); e os professores italianos Damiano Canale e Giovanni Tuzet apontam para um fato importante: "a analogia e a interpretação extensiva chegam ao mesmo resultado a partir dos mesmos materiais jurídicos: ambos justificam a extensão de um regulamento a um caso que não é explicitamente considerado pela lei" (2014, p. 228). O artigo de Canale e Tuzet, "Analogical reasoning and extensive interpretation", fornece um excelente contraponto a qualquer tentativa de diferenciação entre a analogia e a interpretação extensiva. Se o jurista pode alcançar o mesmo resultado com ambas as técnicas, então elas não passariam de modos distintos para um mesmo tipo de argumentação. Partindo da famosa regra hipotética "É proibida a entrada de veículos no parque", um juiz que busca fundamentar a proibição da entrada de skates pode fazer uso tanto da analogia quanto da interpretação extensiva. 
Imaginemos duas hipóteses. Na primeira, há um juiz que interpreta a palavra veículo como significando "meio de transporte motorizado". Mas ele vislumbra a possibilidade de ampliar esse significado para abarcar outras situações, por entender que o legislador disse menos do que gostaria de ter dito e porque o campo semântico da palavra permite essa extensão. Nesse sentido, ele proibirá a entreda do skate no parque, justificando sua decisão através de uma interpretação extensiva da norma jurídica. Na segunda situação, há um juiz que interpreta a palavra veículo como significando tão somente "meio de transporte motorizado, e nada mais. Ele não vislumbra a possibilidade de ampliar esse significado. Logo, a situação que ora se apresenta (é permitida a entrada de skates no parque?) se traduz em uma lacuna jurídica. Diante dessa lacuna, o juiz poderá integrar o ordenamento jurídico através da analogia. Seu argumento será nesse sentido: a norma jurídica proíbe a entrada de veículos no parque; skate não é um veículo; mas um skate é semelhante a um veículo, tendo em vista que ambos são meios de transporte e que podem causar riscos aos frequentadores do parque; logo, o mesmo tratamento dispensado aos veículos deve ser estendido também para o skate. Nessa segunda situação, o juiz proibirá a entrada do skate no parque, justificando sua decisão através da analogia. Nas duas situações, duas justificativas diferentes.

E há ainda outro problema: se a analogia e a interpretação extensiva podem levar ao mesmo resultado, há um problema que ultrapassa a questão conceitual. Esse outro problema foi abordado por Karl Engisch. Após apontar a fluidez da linha que separa a analogia da interpretação extensiva, ele afirma: "E isto tem importância prática, nomeadamente quando seja juridicamente permitida toda e qualquer espécie de interpretação, mas seja proibida, ao invés, uma aplicação analógica dos preceitos jurídicos" (1996, p. 294).

No caso do direito penal brasileiro, que permite a interpretação extensiva (seja a favor ou em prejuízo do réu) mas proíbe a analogia (quando em prejuízo do réu), a falta de uma demarcação clara para os seus âmbitos de atuação pode representar um perigo para o ideal do estado de direito. 
Os problemas suscitados demonstram a necessidade de uma pesquisa que aborde a distinção entre a analogia e a interpretação extensiva. Quando o colega professor de direito penal citado no primeiro parágrafo dessa introdução disse que "até hoje o direito penal brasileiro não consegue explicar a diferença entre a analogia e a interpretação extensiva", ele não estava dizendo que os manuais brasileiros não abordam o tema. O que ele quis dizer pode ser resumido na seguinte frase: "o problema é que, na prática jurídica, é muito difícil distinguir a analogia da interpretação extensiva" (CANALE e TUZET, 2014, p. 228).

Apesar das discussões no âmbito do direito penal, a presente tese é primordialmente um trabalho de teoria do direito. Seu objetivo é apresentar um estudo da analogia e da interpretação extensiva que consiga responder aos seguintes questionamentos: (i) Quais são as semelhanças entre analogia e interpretação extensiva? (ii) Os critérios de distinção usualmente apontados se sustentam?

Para tanto, a tese possui a seguinte estrutura. O capítulo 2 irá apresentar os seus personagens principais - analogia e interpretação extensiva -, tendo como base a literatura jurídica brasileira; dessa forma, o leitor é apresentado à visão unânime da teoria do direito brasileira sobre o tema: analogia e interpretação extensiva são técnicas distintas e que não se confundem. O capítulo 3 apresentará uma visão concorrente, capitaneada por Damiano Canale e Giovanni Tuzet; essa visão chamará a atenção para algumas semelhanças entre a analogia e a interpretação extensiva e mostrará a dificuldade existente em delimitar o campo de atuação de cada. $O$ capítulo 4 seguirá a tendência do capítulo anterior de questionar a distinção entre analogia e interpretação extensiva, mas a partir de um novo elemento: as discussões oriundas do direito penal brasileiro. Se o direito penal brasileiro permite a interpretação extensiva e proíbe a analogia, o tema investiga ganha uma importância não somente teórica, mas também prática. Esses três primeiros capítulos irão 
apresentar o problema; os capítulos seguintes irão aprofundar o estudo do tema. $O$ capítulo 5 é dedicado a um tipo de argumento comumente empregado na analogia: o argumento analógico. Questionaremos se o argumento analógico é melhor descrito como um argumento dedutivo ou indutivo. A premissa desse capítulo é simples: assim que dividimos um argumento em seus componentes, estamos aptos a brincar com as engrenagens. Uma dessas engrenagens, talvez a mais importante, é o raciocínio analógico, que será abordado no capítulo 6 . Todo argumento por analogia busca realçar as semelhanças entre dois objetos; mas, como é possível inferir de forma intuitiva, é possível encontrar semelhanças mesmo entre os objetos mais díspares. Como funciona o raciocínio analógico? Para responder a essa pergunta, a tese irá se debruçar sobre as pesquisas realizadas nas últimas décadas no campo das ciências cognitivas. Vários cientistas e psicólogos realizaram experimentos com o intuito de entender o processo cognitivo responsável pelos nossos julgamentos de similaridade, e os resultados desses experimentos serão importantes para a compreensão do raciocínio analógico - e, consequentemente, para a compreensão da analogia e da interpretação extensiva no contexto da teoria do direito. A contribuição das ciências cognitivas fornecerá a resposta para a primeiras das duas perguntas que esta tese se propõe a enfrentar: Quais são as semelhanças entre analogia e interpretação extensiva? Por fim, o último capítulo é dedicado a segunda pergunta: Os critérios de distinção usualmente apontados se sustentam?

Ao final, a pretensão da presente tese é demonstrar para o leitor que existem mais semelhanças que diferenças entre a analogia e a interpretação extensiva. Se ela conseguir chamar a atenção para o tema, aumentando o volume do ruído, terá cumprido o seu papel. 


\section{2}

\section{Um conto de duas cidades: analogia e interpretação extensiva}

Quando se trata da analogia e da interpretação extensiva, a doutrina brasileira é unânime não somente no sentido de afirmar a diferença entre elas, mas também nas razões que a justificam. Alguns exemplos:

A analogia ocupa-se com uma lacuna do Direito Positivo, com hipótese não prevista em dispositivo nenhum, e resolve esta por meio de soluções estabelecidas para casos afins; a interpretação extensiva completa a norma existente, trata de espécie já regulada pelo Código, enquadrada no sentido de um preceito explícito, embora não se compreenda na letra deste. (...) Do exposto já ficou evidente não ser lícito equiparar a analogia à interpretação extensiva (MAXIMILIANO, 2002, p. 175).

Não se deve confundir a analogia com a interpretação extensiva, apesar de, como já assinalamos, esta representar, até certo ponto, uma forma de integração. (...) Podemos dizer que o pressuposto do processo analógico é a existência reconhecida de uma lacuna na lei. Na interpretação extensiva, ao contrário, parte-se da admissão de que a norma existe, sendo suscetível de ser aplicada ao caso, desde que estendido o seu entendimento além do que usualmente se faz (REALE, 2003, p. 297-298).

O cuidado especial com a interpretação extensiva provoca uma distinção entre esta e a interpretação por analogia. A doutrina afirma que a primeira se limita a incluir no conteúdo da norma um sentido que já estava lá, apenas não havia sido explicitado pelo legislador. Já na 
segunda, o intérprete toma de uma norma e aplica-a um caso para o qual não havia preceito nenhum, pressupondo uma semelhança entre os casos. (...) A distinção, porém, não é rigorosa (FERRAZ JR., 2007, p. 310-311).

A interpretação extensiva dilata o significado até o ponto máximo que o termo permite. Pode ser admitida se o intérprete indicar os motivos pelos quais a interpretação declarativa não corresponde à verdadeira vontade do legislador. Para tanto, o intérprete deve comprovar que o legislador disse menos do que pretendia, devendo o intérprete corrigir esse problema, ajustando a norma às intenções do legislador. (...) No caso da analogia, o intérprete excede o limite do possível significado dos termos legais. A analogia começa onde termina a possibilidade de interpretação extensiva. Temos uma interpretação analógica quando se considera que uma norma rege determinadas situações, apesar da impossibilidade de subsumir essas situações aos termos da norma. A analogia se justifica pela constatação de que os casos contemplados pela norma apresentam grandes semelhanças com os não contemplados (DIMOULIS, 2011, p. 155).

Ainda que sejam técnicas próximas, não se pode confundir a analogia e a interpretação extensiva. A diferença mais elementar é que enquanto na "interpretação extensiva" a discussão se mantém no campo semântico do texto legal existente, no caso da "analogia" não existe disciplina para o caso ao qual se procura solucionar (SGARBI, 2013, p. 145).

Ler essas citações em conjunto, uma após a outra, é interessante por dois motivos.

Primeiro, porque elas realçam o entendimento da doutrina brasileira no sentido de que a analogia e a interpretação extensiva são, apesar da proximidade, estratégias ${ }^{1}$ distintas: enquanto a analogia atribui a um caso não regulamentado pelo direito a mesma disciplina conferida a um caso semelhante já regulamentado, a interpretação extensiva é uma operação interpretativa que expande o campo semântico das disposições legais.

\footnotetext{
${ }^{1} \mathrm{Na}$ última edição do "Curso de Teoria do Direito", Adrian Sgarbi apresenta a analogia e a interpretação extensiva como estratégias a serem adotadas pelo jurista para a solução dos problemas de ausência e insuficiência de previsão normativa (SGARBI, 2020, p. 279-284).
} 
Segundo, porque elas acabam por revelar os pressupostos conceituais tanto da analogia quanto da interpretação extensiva.

\section{1}

\section{Analogia}

No caso da analogia, o pressuposto conceitual é a existência de uma lacuna jurídica.

Todo ordenamento jurídico pretende ser completo (BOBBIO, 1995, p. 35). Ou seja, todo ordenamento jurídico - em especial naqueles que determinam a obrigatoriedade de os juízes julgarem todas as controvérsias que lhe forem apresentadas e de fazê-los com base em uma norma jurídica válida e vigente ${ }^{2}$ - pretende ter ao menos uma norma jurídica apta a regular qualquer caso. Essa pretensão, porém, busca uma miragem. Pelos mais variados motivos - vagueza, ambiguidade ou a impossibilidade de conhecer o futuro -, todo ordenamento jurídico está fadado à incompletude. Ainda mais em uma sociedade como a atual: com evoluções sociais e tecnológicas são tão rápidas e constantes, o legislador dificilmente conseguirá agir de forma preventiva; fatalmente ele se verá diante da necessidade de regular uma situação nunca antes imaginada. Daí a necessidade de se falar em lacunas jurídicas.

O que é uma lacuna jurídica? Em um primeiro momento, pode-se afirmar que lacuna é o nome dado à situação que ocorre quando não

2 Como é o caso do ordenamento jurídico brasileiro, conforme pode ser observado da leitura dos seguintes artigos: art. $5^{\circ}, \mathrm{CF} / 88$ : a lei não excluirá da apreciação do Poder Judiciário lesão ou ameaça de direito; art. 93, IX, CF/88: todos os julgamentos dos órgãos do Poder Judiciário serão públicos, e fundamentadas todas as decisões, sob pena de nulidade (..); art. 140, CPC/2015: o juiz não se exime de decidir sob a alegação de lacuna ou obscuridade do ordenamento jurídico. 
existe, no ordenamento jurídico, uma norma disponível para a resolução de determinada controvérsia; é quando o jurista se vê diante de um problema e, ao se voltar para o ordenamento jurídico em busca de uma solução, nada encontra. Se, por exemplo, um advogado é procurado por um cliente que quer saber se é possível dar início ao processo de inventário do pai que está congelado em uma câmara criogênica, ele não encontrará no ordenamento jurídico brasileiro qualquer norma que trate especificamente dessa situação.

Mas, ao se analisar as situações de lacuna às quais o jurista pode se deparar, percebe-se que a situação é mais complexa do que parece em um primeiro momento. O termo "lacuna" é ambíguo, podendo ser utilizado em diferentes contextos. Adrian Sgarbi (2013, p. 129-130) apresenta quatro usos habituais: ontológico, técnico, axiológico ou lógico. (i) A lacuna ontológica ocorre quando não há, no ordenamento jurídico, uma norma jurídica que regulamente determinada controvérsia; o texto legal ignora algum tipo de conduta. (ii) A lacuna técnica pressupõe a existência de uma norma que, isolada, não consegue produzir os seus efeitos, sendo necessária a criação de uma norma posterior que a regule; enquanto faltar a norma posterior, há uma situação de lacuna. (iii) $\mathrm{A}$ lacuna axiológica se caracteriza não pela ausência de norma, mas sim pela ausência de uma norma justa; ou seja, existe uma norma apta para a solução de determinado caso, porém o jurista não a considera correta ou justa. (iv) Por fim, a lacuna lógica ocorre não em razão da ausência de norma, mas sim em razão do seu excesso: há mais de uma norma jurídica apta para solucionar o caso, porém elas são contraditórias. E, além desses quatro usos, Fábio Shecaira e Noel Struchiner (2016, p. 103-104) apresentam também a chamada lacuna em sentido neutro, utilizada para se referir a situações em que o texto legal não regula claramente algum tipo de conduta. $O$ exemplo que os autores utilizam é a de uma lei que regula o uso de motocicletas. Estariam as bicicletas elétricas reguladas pela mesma lei? Se, em um primeiro momento, uma lacuna jurídica pode ser compreendida como a ausência de norma legal para regular determinada situação, os autores apresentam uma hipótese de lacuna na 
qual existe uma norma, mas o jurista fica se em dúvida se essa norma regula ou não o caso que lhe interessa. A norma em questão não é clara o suficiente. "Estamos diante de uma lacuna, em sentido neutro, quando abordamos a lei de acordo com o método gramatical e não conseguimos determinar qual solução ela dá à questão que nos interessa. O texto simplesmente não é claro em relação ao caso em questão" (2016, p. 104).

Apesar dos diferentes usos do termo "lacuna" (mas excluindo a lacuna axiológica), é possível observar um ponto em comum: o jurista está diante de uma lacuna jurídica quando o ordenamento jurídico não confere uma resposta clara para determinada controvérsia - seja porque inexiste norma que regule aquela situação, seja porque a norma existente é vaga, ambígua ou contraditória.

Independente do uso do termo, fatalmente o jurista irá se deparar com uma lacuna jurídica. Quando isso acontecer, o que ele pode fazer? Como solucionar uma situação de lacuna jurídica?

A analogia é uma das respostas possíveis.

Dispõe o artigo $4^{\circ}$ da Lei de Introdução às Normas do Direito Brasileiro: "Quando a lei for omissa, o juiz decidirá o caso de acordo com a analogia, os costumes e os princípios gerais do direito". Portanto, quando diante de uma lacuna jurídica, a analogia figura entre os métodos (juntamente com os princípios, a jurisprudência, os costumes e a doutrina) que o jurista pode utilizar para a integração do ordenamento jurídico.

Norberto Bobbio entende por analogia "o procedimento pelo qual se atribui a um caso não regulamentado a mesma disciplina que a caso regulamentado semelhante" (1995, p. 151). Ou seja: há uma situação original já regulada pelo direito (seja pela lei ou pela jurisprudência) e outra semelhante (chamemos de situação em debate) não regulada pelo direito; como regular a situação em debate? Se a situação em debate for juridicamente semelhante à situação original, pode-se argumentar que, por analogia, a situação em debate deve ser juridicamente regulada da mesma forma que a situação original. 
O exemplo que Bobbio (1995, p. 153) apresenta envolve uma lei de um estado norte-americano ${ }^{3}$ que proíbe a venda de livros obscenos - e pergunta: e o comércio de discos obscenos? Se não há qualquer norma jurídica que regule a venda de discos obscenos, essa lacuna pode ser solucionada através da analogia. "Livros obscenos" é a situação original; "discos obscenos" é a situação em debate. Dada a semelhança entre as duas situações - a obscenidade, razão da proibição dos livros - e o imperativo da igualdade - situações semelhantes devem ser tratadas de forma semelhante -, o caso não regulamentado deve ser regulamentado da mesma forma que o caso regulado: proibindo, portanto, a venda dos discos obscenos.

Enquanto técnica de integração do ordenamento jurídico, a analogia é um tipo de argumento. Conforme Shecaira e Struchiner (2016, p. 113), ele pode ser representado através da seguinte estrutura:

1. Uma situação $\mathrm{S} 1$ é juridicamente regulada da maneira $\mathrm{M}$.

2. S1 é semelhante a outra situação $S 2$ no que diz respeito às características juridicamente relevantes $\mathrm{C} 1, \mathrm{C} 2, \ldots \mathrm{Cn}$.

Logo,

3. S2 deve ser juridicamente regulada da mesma maneira M.

É importante observar que a analogia soluciona uma lacuna do ordenamento jurídico utilizando um material jurídico do próprio ordenamento. A solução para uma lacuna do ordenamento vem, por assim dizer, "de dentro". Ao expor os meios que o jurista dispõe para solucionar as lacunas jurídicas, Bobbio os divide em dois grupos: a heterointegração e a auto-integração. Na heterointegração, a lacuna é solucionada através de recursos à ordenamentos diversos e à fontes diversas daquela que é a dominante (BOBBIO, 1995, p. 145). É o caso, por exemplo, de uma lacuna solucionada a partir de um ordenamento jurídico historicamente distante (como o direito romano) ou através dos

${ }^{3}$ Ele não informa qual estado. 
costumes - que, apesar de figurarem como fontes do direito, estão longe de serem consideradas as fontes dominantes. Já na auto-integração ocorre o oposto: nele, a lacuna é solucionada a partir do próprio ordenamento jurídico e no âmbito da fonte dominante (BOBBIO, 1995, p. 146). A analogia é um exemplo de auto-integração. Seria razoável supor que, dos dois grupos, a heterointegração é a mais utilizada; afinal, se o ordenamento possui uma lacuna, então a resposta terá que vir "de fora". Mas o que ocorre é exatamente o contrário. As técnicas de autointegração são as mais utilizadas pelos juristas quando estes se deparam com uma lacuna. Um reflexo, talvez, da diversidade de usos que o termo "lacuna" comporta e, também, de uma questão de legitimidade: a solução é "encontrada" no próprio ordenamento.

Um exemplo pode ser útil para demonstrar todas as características expostas nos parágrafos anteriores.

No ano de 2007 o Supremo Tribunal Federal concluiu o julgamento (conjunto) dos Mandados de Injunção 670, 708 e 712, garantindo o exercício de um direito que não tinha respaldo legal graças a uma omissão que perdurava desde a promulgação da Constitucional de 1988. No caso, a discussão girava em torno do direito de greve dos servidores públicos. Apesar de a Constituição garantir o direito de greve no artigo $9^{\circ}$ ("é assegurado o direito de greve, competindo aos trabalhadores decidir sobre a oportunidade de exercê-lo e sobre os interesses que devam por meio dele defender"), o parágrafo primeiro do mesmo artigo estabelece que: "a lei definirá os serviços ou atividades essenciais e disporá sobre o atendimento das necessidades inadiáveis da comunidade". A "lei" a que se refere o parágrafo primeiro, responsável pela regulamentação do direito de greve - e, consequentemente, pela sua eficácia -, ainda não havia sido criada à época da promulgação da Constituição. Além disso, há ainda o inciso VII do artigo 37 (que dispõe sobre a administração pública): "o direito de greve será exercido nos termos e nos limites definidos em lei específica". Da mesma forma, essa "lei" também não existia. A referência a leis que não existem configura, na realidade, uma 
escolha do Poder Constituinte Originário: a de deixar para o Congresso Nacional a tarefa de aprovar lei que regulamente o exercício do direito de greve. Uma enorme responsabilidade, pois, enquanto não sobrevier a atuação legislativa federal, um direito constitucionalmente assegurado não poderá ser gozado.

Mas a lei foi criada. No dia 28 de junho de 1989, oito meses após a promulgação da Constituição, é promulgada a Lei Geral da Greve - lei 7.783. O problema: essa lei regulou somente o direito de greve dos trabalhadores do setor privado, nada dispondo sobre os servidores públicos. Para estes, o direito de greve continuava a ser uma promessa.

O artigo 37, VII da Constituição é, na clássica definição elaborada por José Afonso da Silva, uma norma de eficácia limitada. Conforme aponta, as normas constitucionais podem ser diferenciadas - e, consequentemente, classificadas -, quanto à eficácia. "Tratando-se de normas jurídicas, a eficácia consiste na capacidade de atingir os objetivos nela traduzidos, que vêm a ser, em última análise, realizar os ditames jurídicos objetivados pelo legislador" (SILVA, 1998, p. 66). As normas de eficácia limitada são aquelas que, isoladas, não conseguem produzir efeitos - elas precisam de uma norma posterior que as regulem. A ausência de norma posterior reguladora não somente impede que uma norma constitucional seja eficaz, mas também (o que é ainda mais grave) impede que um cidadão goze de um direito constitucionalmente assegurado.

No dia 08 de junho de 2004, a Secretaria de Educação do Município de João Pessoa/PB foi informada, através do SINTEM (Sindicato dos trabalhadores em educação do município de João Pessoa), que os professores da rede municipal entrariam em greve por tempo indeterminado em razão das péssimas condições de trabalho a que estariam submetidos. Em resposta, a Administração Pública Municipal requereu a declaração de ilegalidade da greve. Tal pedido foi deferido pelo Presidente do Tribunal de Justiça do Estado da Paraíba; o desconto no salário em relação aos dias não trabalhados foi autorizado. O 
argumento que fundamentou a decisão do tribunal: a greve é ilegal por falta de amparo legal. O artigo 37 , VII da Constituição não possui regulamentação normativa.

Felizmente, o constituinte originário incorporou, na Constituição, um remédio constitucional cuja finalidade é abordar tais omissões legislativas. Com previsão no artigo $5^{\circ}$, LXXI, dispõe que: "conceder-se-á mandado de injunção sempre que a falta de norma regulamentadora torne inviável o exercício dos direitos e liberdades constitucionais e das prerrogativas inerentes à nacionalidade, à soberania e à cidadania". ${ }^{4}$

Esse foi o pano de fundo dos Mandados de Injunção 670, 708 e 712. A decisão do Supremo Tribunal Federal, com o relatório e votos dos onze ministros, somam 177 páginas. ${ }^{5}$ Nela, foi reconhecida a omissão legislativa quanto ao dever constitucional de editar lei que regulamente $o$ exercício do direito de greve no setor público - e que, enquanto a omissão não for sanada, será aplicada para o setor público a lei de greve vigente para o setor privado. Como as situações são juridicamente semelhantes, elas podem, por analogia, ter a mesma regulamentação.

A solução do Supremo Tribunal Federal para solucionar a lacuna em questão foi alcançada através da analogia. A greve dos servidores públicos é a situação em debate. A greve dos trabalhadores do setor privado é a situação original. As duas situações não são iguais; há diferenças entre elas - mas, apesar das diferenças, há semelhanças juridicamente relevantes. Semelhanças juridicamente relevantes essas que podem justificar o mesmo tratamento jurídico. Logo, se a situação original é regulada pela lei 7.783 e a situação em debate não possui norma reguladora, então esta deve ser regulada da mesma forma que aquela. Conforme afirmou o ministro Carlos Alberto Menezes Direito em seu voto, "O Supremo pode analogicamente autorizar a aplicação da lei geral (Lei 7.783/89) para suprir a ausência de norma que assegure o

\footnotetext{
${ }^{4}$ Curiosamente, o mandado de injunção só ganhou norma que disciplinasse o seu processo e julgamento em 2016, quando foi promulgada a lei 13.300 .

${ }^{5} \mathrm{O}$ inteiro teor do acórdão está disponível em: https://bit.ly/2W14Uzm. Acesso em 05 dez. 2020.
} 
direito constitucional" - e ainda complementa, abordando o aspecto da legitimidade das técnicas de auto-integração citada acima:

Ao converso do que se poderia pensar, entendo que a utilização desse instrumento, posto à disposição dos julgadores, reforça a ideia da separação de poderes, porque se está utilizando um instrumento legislativo, uma norma legislativa, uma norma estatal, para cobrir a ausência que inviabiliza o exercício de direito que a Constituição prescreve (MI 708/DF, p. 295)

É possível perceber, nos Mandados de Injunção 670, 708 e 712, todos os elementos que acompanham a aplicação da analogia: a existência de uma lacuna (que, no caso em questão, é uma lacuna técnica) e a consequente solução dessa lacuna através do recurso à "norma cuja previsão, embora se dirija a caso distinto, apresenta semelhanças com a situação imprevista" (SGARBI, 2013, p. 142).

\section{2}

\section{Interpretação extensiva}

Já no caso da interpretação extensiva, o pressuposto de incidência é a possibilidade de expansão do campo semântico das disposições legais.

Em textos que buscam explicar o que é a interpretação extensiva, é comum encontrarmos a citação do brocardo latino lex minus dixit quam voluit - "a lei disse menos do que queria dizer". É possível que alguém fale menos (ou mais) do que queria dizer? 
Imaginemos a seguinte situação ${ }^{6}$. Um crítico gastronômico vai até um restaurante recém-inaugurado para escrever uma crítica de jornal. Chegando ao restaurante, ele é recepcionado pelo chef que, após acomodá-lo em uma mesa e lhe entregar o cardápio, sugere o prato da casa: Cupim na manteiga de garrafa. Quando o crítico começa a degustação, o chef senta à mesa e começa a explicar sua criação: "Esse é o prato principal da casa. Eu sempre gostei de cupim; era a primeira carne que eu pedia quando era moleque e ia à churrascaria com o meu pai. Mas cupim não é para ser servido somente na churrascaria. Minha intenção é popularizar essa carne. Acredito que não existe carne de segunda; existe carne mal feita. Ela é cozida na água, somente com sal. Depois vai ao forno; são quatro horas enrolada em papel celofane. Depois, antes de servir, eu aqueço na frigideira com manteiga de garrafa. Para acompanhar, mandioca amarela e uma farofa de farinha de mandioca e banana".

Quando termina de comer, o chef pergunta: "E aí? Gostou do prato?"

Ao responder, o crítico se limita a dizer: "Gostei da farofa".

Interpretada de forma literal, a resposta do crítico significa exatamente o que ele quis dizer: que ele gostou da farofa. Mas essa resposta possui um significado maior do que aquele captado através da sua literalidade. $\mathrm{O}$ chef pode esperar uma crítica negativa.

Intuitivamente, todos nós sabemos que, muitas vezes, o que um falante quer dizer vai além daquilo que ele literalmente diz. Se uma pessoa pergunta para outra "você pode fechar a porta?", ela não quer saber se ela efetivamente consegue fechar uma porta. Se uma pessoa pergunta para outra "quer um café" e ela responde "bem, o café não me deixa dormir", essa resposta pode ter vários significados: além do significado literal, pode significar uma recusa (se a pessoa não quer ter o

\footnotetext{
${ }^{6}$ Adaptado do vídeo "Jota Bê entrevista Henrique Fogaça, do Masterchef, e avalia o restaurante SAL", disponível em: https://bit.ly/3hqedCi. Acesso em: 05 dez. 2020.
} 
sono prejudicado) ou até mesmo um sim (se a pessoa é um doutorando com uma tese para escrever).

No âmbito da filosofia da linguagem, esse conhecimento intuitivo foi investigado por Paul Grice. ${ }^{7}$ Em artigos como Logic and Conversation (1989a) e Meaning (1989b), Grice apresenta a distinção entre o significado sentencial e o significado do falante: o primeiro procura captar o significado literal de uma sentença, enquanto o segundo diz respeito ao que o falante realmente tem a intenção de comunicar. $O$ significado sentencial da frase "João é um excelente administrador" remete ao seu significado literal - a de que João é um administrador. Mas, se essa frase foi dita como resposta à pergunta "João é um bom filósofo?", percebe-se que a intenção do falante diverge do seu significado literal. Em muitas ocasiões, para compreender o que alguém quer dizer é necessário ir além daquilo que ele diz; é necessário atentar-se também para o que ele sugere, indica, insinua.

Obviamente, descobrir o significado do falante é uma tarefa infinitamente mais difícil do que descobrir o significado literal. Como descobrir a intenção de uma pessoa? Não há uma resposta simples para essa pergunta; há, inclusive, todo um campo da filosofia da linguagem dedicada a essa investigação (a pragmática). De modo singelo, é possível dizer que o significado do falante poderá ser descoberto através do contexto que envolve a fala (MILLER, 2010, p. 72).

Mas, e no caso de uma norma jurídica? Como descobrir se o legislador disse menos do que gostaria de ter dito? Como reinterpretar uma norma de forma a alongar o seu campo semântico?

\footnotetext{
${ }^{7}$ Não que Paul Grice tenha sido o primeiro filósofo a analisar a distância entre o que é dito e a aquilo que se quer dizer. Gottlob Frege, por exemplo, já discutia as propriedades semânticas da força e do tom: as sentenças "Paulo é paulista e um bom perdedor" e "Paulo é paulista, mas é um bom perdedor" possuem o mesmo significado literal, mas o tom é diferente (DUMMETT, 1973, p. 1-8). Mas Paul Grice foi o primeiro a fazer uma análise filosófica dessa característica da linguagem (WHARTON, 2002, p. 214).
} 
Entre os recursos mais utilizados pelos juristas para alcançar essa finalidade estão a ratio legis e a evolução da consciência jurídica (SGARBI, 2013, p. 145). Pela ratio legis, o intérprete afirma a existência de uma finalidade na lei que permite a ampliação ou restrição do seu campo semântico (CANALE e TUZET, 2010,.p. 197). O artigo 5, XI da Constitucional Federal, por exemplo, dispõe que "a casa é asilo inviolável do indivíduo, ninguém nela podendo penetrar sem o consentimento do morador, salvo em caso de flagrante delito ou desastre, ou para prestar socorro, ou, durante o dia, por determinação judicial”. A indeterminação, aqui, fica por conta da palavra "casa" - o seu significado jurídico compreende somente um edifício destinado à habitação ou é possível abranger outras situações? Uma forma de responder essa questão é através do recurso à ratio legis. Qual é a finalidade dessa proteção constitucional? Com a ajuda dos Anais da Assembleia Constituinte e da doutrina constitucional, é possível apreender que a finalidade dessa norma foi a de garantir a inviolabilidade domiciliar - e, em último grau, resguardar a privacidade. Se, portanto, a intenção da norma é garantir a privacidade, é razoável entender o significado de "casa" de forma mais ampla, compreendendo também escritórios, oficinas, garagens. ${ }^{8}$ Já as considerações pertinentes à evolução da consciência jurídica partem do pressuposto de que as disposições jurídicas devem ser interpretadas de forma a acompanhar as mudanças sociais. O sentido literal da lei, quando editada, estaciona no tempo; a sociedade, por outro lado, está em constante evolução. Uma interpretação literal, portanto, será insuficiente para responder aos anseios da sociedade - o que pode ser solucionado a

\footnotetext{
${ }^{8}$ Esse foi, inclusive, o entendimento firmado pelo Supremo Tribunal Federal no julgamento do Recurso Ordinário em Habeas Corpus 90.376. Na ocasião, o questionamento era sobre a legitimidade de um mandado de busca e apreensão cumprido em um quarto de hotel. É válido ampliar o conceito de "casa" para englobar os quartos de hotéis? Em seu voto, o Ministro Relator Celso de Mello afirmou: "Para os fins da proteção jurídica a que se refere o art. $5^{\circ}, \mathrm{XI}$, da Constituição da República, o conceito normativo de 'casa' revela-se abrangente e, por estender-se a qualquer aposento de habitação coletiva, desde que ocupado (CP, art. 150, $\left.\S 4^{\circ}, \mathrm{II}\right)$, compreende, observada essa específica limitação espacial, os quartos de hotel" (RHC 90.376, Rel. Min. Celso de Mello, DJ de 18.05.2007).
} 
partir de uma interpretação que amplie o sentido da norma de forma a abarcar essas evoluções.

Ambas as hipóteses - a ratio legis e a evolução na consciência jurídica - demonstram que o sentido literal de uma norma jurídica nem sempre corresponderá à intenção do legislador. Nesse sentido, ao discorrer sobre os tipos de interpretação do direito, a doutrina faz menção a interpretação restritiva e a interpretação extensiva.

Uma interpretação restritiva busca limitar o sentido da norma jurídica. Aqui, da mesma forma como na interpretação extensiva, sua explicação geralmente vem acompanhada de um brocardo jurídico: lex magis dixit quam voluit - "a lei disse mais do que queria dizer". Através dela, o intérprete restringe o significado jurídico para aquém daquele que seria alcançado por uma interpretação literal. O artigo 220 da Constituição Federal (inserido no capítulo "Da Comunicação Social"), por exemplo, dispõe que "A manifestação do pensamento, a criação, a expressão e a informação, sob qualquer forma, processo ou veículo, não sofrerão qualquer restrição, observado o disposto nesta Constituição". Interpretada literalmente, essa norma proibiria qualquer restrição à liberdade de expressão; porém, conforme inúmeros posicionamentos doutrinários e decisões do Supremo Tribunal Federal, a liberdade de expressão pode sim sofrer limitações, principalmente quando violar outro direito fundamental. ${ }^{9}$ A Constituição buscou proteger também outros valores que

\footnotetext{
${ }^{9}$ No âmbito jurisprudencial, cita-se, como exemplo, um pequeno jornal da cidade de Santa Cruz do Rio Pardo foi condenado a pagar o valor de $\mathrm{R} \$ 593$ mil a título de indenização por danos morais em razão de uma reportagem em que se afirmava que a Prefeitura pagava o aluguel e a conta telefônica de um magistrado lotado na cidade (MILíCIO, 2009). Já no âmbito doutrinário, Fábio Carvalho Leite, no artigo Liberdade de expressão e direito à honra: novas diretrizes para um velho problema, argumenta que não há nenhuma garantia de que um discurso, apesar de não poder ser proibido pelo governo (o que caracterizaria a censura), não será condenado pelo Judiciário: "A restrição imposta pelo Poder Judiciário, no entanto, não é compreendida como um problema sequer semelhante ao que decorre da censura. $E$ isso por uma série de razões: (i) nestes casos é assegurada a liberdade de expressão, na medida em que não há censura prévia; (ii) a liberdade de expressão não é nem poderia ser um direito absoluto; (iii) a Constituição protege outros valores, como a honra, a imagem, a vida privada e a intimidade (art. $5^{\circ}, \mathrm{X}$ ); (iv) cabe ao Poder Judiciário a função justamente de dirimir uma lide, dizendo o direito num caso concreto; (v)
} 
não a liberdade de expressão, e é razoável afirmar que o constituinte originário não quis estabelecer a liberdade de expressão como um valor absoluto - como pode ser observado, aliás, por outros dispositivos constitucionais, como o artigo $5^{\circ}$, V: "é assegurado o direito de resposta, proporcional ao agravo, além de indenização por dano material, moral ou à imagem". Por todos esses motivos é possível interpretar de forma restritiva o já citado artigo 220 da Constituição, pois, como afirma Tercio Sampaio Ferraz Jr., "a mera interpretação literal não atinge os objetivos da norma, pois lhe confere uma amplitude que prejudica os interesses, ao invés de protegê-los" (2007, p. 308). O legislador disse mais do que queria dizer.

$\mathrm{Na}$ interpretação extensiva ocorre o contrário. Dessa vez, o legislador disse menos do que queria dizer.

A lei 3.373, de 1958, que dispõe sobre o pagamento de pensões especiais instituídas por ex-servidores da Administração Pública Federal, estabelece no $\S$ único do artigo $5^{\circ}$ que "a filha solteira, maior de 21 anos, só perderá a pensão temporária quando ocupante de cargo público". Tendo em vista a ratio legis ou a evolução da consciência jurídica, é possível reinterpretar essa norma de forma a ampliar o seu significado, englobando outras hipóteses. Foi exatamente isso o que fez o Supremo Tribunal Federal ao julgar o Recurso Extraordinário 114.293; no voto, o Ministro Relator Francisco Rezek realizou interpretação extensiva para conceder o benefício "às filhas viúvas, separadas judicialmente ou divorciadas que vivem sob a dependência econômica do segurado".

Tercio Sampaio Ferraz Jr. (2007, p. 309) usa o termo "direitos do homem" para exemplificar a utilização da interpretação extensiva: "Tomada literalmente, a expressão haveria de referir-se apenas ao ser humano, em sentido psicofísico. A doutrina, contudo, para atingir um espectro maior de proteção, dá-lhe uma interpretação extensiva". No

a própria Constituição, após estabelecer que 'é livre a manifestação do pensamento', assegurou, como contrapartida, não apenas o 'direito de resposta, proporcional ao agravo', como a possibilidade de indenização por dano material, moral ou à imagem (2014, p. 395-396). 
caso, a referência é à possibilidade de se estender os direitos fundamentais previstos no artigo $5^{\circ}$ da Constituição também para as pessoas jurídicas.

Quando, portanto, a interpretação literal falhar na tarefa de fazer cumprir a intenção do legislador, as interpretações restritivas e extensivas podem ser utilizadas para respeitar a ratio legis ou acompanhar a evolução da consciência jurídica. Ambas intentam diminuir a distância entre o que foi dito e o quis ser dito.

\section{3}

\section{Analogia e interpretação extensiva lado a lado}

Do que foi apresentado até aqui sobre a analogia e a interpretação extensiva, é possível resumir quatro pontos de diferença entre elas:

(i) A analogia é uma técnica de integração, enquanto a interpretação extensiva é um tipo de interpretação. $\mathrm{O}$ ato de interpretar antecede a analogia: o recurso à analogia somente será utilizado após o jurista ter interpretado uma norma e chegado à conclusão que ela não regula o caso em questão.

(ii) A analogia é utilizada quando não há norma que regule o caso em questão, enquanto na interpretação extensiva há norma reguladora. Tendo em vista a primeira distinção, há na analogia uma lacuna a ser solucionada, ao contrário da interpretação extensiva, na qual não se configura a existência de lacuna jurídica.

(iii) Na analogia, aplica-se uma norma que regula fato semelhante ao caso em questão, enquanto na interpretação 
extensiva amplia-se o alcance das palavras contidas na norma. A analogia atribui a um caso não regulamentado pelo direito a mesma disciplina conferida a um caso semelhante já regulamentado; já a interpretação extensiva é uma operação interpretativa que expande o campo semântico das disposições legais.

(iv) Na analogia, há a criação de uma nova norma, enquanto na interpretação extensiva estende-se o significado de uma norma já existente. Sendo a analogia uma técnica de integração das lacunas jurídicas que atribui a um caso não regulado o mesmo tratamento normativo conferido a outro caso semelhante, o resultado alcançado é uma nova norma. Utilizando o exemplo apresentado acima, quando o Supremo Tribunal Federal disciplinou a greve dos servidores públicos com a mesma lei que regulamenta o direito de greve do setor privado, é como se tivesse sido criada uma nova lei. $\mathrm{Na}$ interpretação extensiva, por outro lado, não há a criação de uma nova lei, pois ela tão somente expande o significado de uma norma já existente.

O último ponto é constantemente lembrado pela doutrina, Norberto Bobbio entre eles:

\begin{abstract}
Mas qual é a diferença entre analogia propriamente dita e interpretação extensiva? Foram elaborados vários critérios para justificar a distinção. Creio que o único critério aceitável seja aquele que busca colher a diferença com respeito aos diversos efeitos, respectivamente, da extensão analógica e da interpretação extensiva: o efeito da primeira é a criação de uma nova norma jurídica; o efeito da segunda é a extensão de uma norma para casos não previstos por esta. (...) [Com a interpretação extensiva,] nos limitamos à redefinição de um termo, mas a norma aplicada é sempre a mesma. [Com a analogia,] passa-se de uma norma a outra (1995, p. 155-156).
\end{abstract}

Apresentadas dessa forma, a analogia e a interpretação extensiva realmente parecem técnicas distintas, utilizadas para situações diversas. Entretanto, não podemos deixar de notar que todas essas distinções são baseadas em premissas frágeis. 
A própria existência das lacunas jurídicas é contestada por alguns teóricos da teoria do direito. Apesar da maioria se posicionar no sentido afirmar a incompletude do ordenamento jurídico, há aqueles que apresentam vozes dissonantes. ${ }^{10}$ Hans Kelsen, por exemplo, chega a chamar as lacunas jurídicas de ficções (2006, p. 275). Para ele, o fato de não existir uma norma jurídica específica para determinado caso não implica que o legislador foi omisso - ao contrário, o "silêncio" do legislador pode ter sido intencional, abrindo margem para que o jurista interprete que "está permitido tudo aquilo que não está expressamente proibido pelo direito". ${ }^{11} \mathrm{O}$ artigo $5^{\circ}$, inciso II da Constituição Federal dá azo a esse entendimento: ninguém será obrigado a fazer ou deixar de fazer alguma coisa senão em virtude de lei. Se não existe lei proibindo os professores universitários de lecionarem trajando bermudas, isso não significa que o legislador foi omisso; tirando a proibição da comercialização da cerveja para os menores de 18 anos, não há outra norma no direito brasileiro que autorize ou proíbe expressamente o seu consumo - logo, deve-se entender que a conduta é lícita, e não que ela configura uma situação de lacuna jurídica (DIMOULIS, 2011, 161).

Da mesma forma, a premissa da interpretação extensiva - a possibilidade de expansão do campo semântico das disposições legais -

\footnotetext{
${ }^{10}$ Assim resume Dimitri Dimoulis: "A doutrina sugere duas formas para tratar o problema das lacunas. Alguns doutrinadores sustentam que o ordenamento jurídico é aberto e incompleto (tese da incompletude). Existiriam casos em que não se pode dar resposta a um problema de aplicação do direito. Em tais casos, o juiz deveria decidir livremente, criando novas normas para preencher a lacuna. Outros doutrinadores consideram, ao contrário, que o ordenamento jurídico é fechado e completo e oferece sempre uma resposta (tese da completude). Isso ocorre porque o direito contém normas dinâmicas que distribuem competências e direito. Havendo dúvidas sobre a vontade do legislador, a decisão cabe à autoridade competente ou fica à disposição dos titulares dos direitos fundamentais" (2011, p. 160-161).

11 "Do que fica dito resulta que uma ordem jurídica pode sempre ser aplicada por um tribunal a um caso concreto, mesmo na hipótese de essa ordem jurídica, no entender do tribunal, não conter qualquer norma geral através da qual a conduta do demandado ou acusado seja regulada de modo positivo, isto é, por forma a impor-lhe o dever de uma conduta que ele, segundo a alegação do demandante privado ou do acusador público, não realizou. Com efeito, neste caso, a sua conduta é regulada pela ordem jurídica negativamente, isto é, regulado pelo fato de tal conduta não lhe ser juridicamente proibida e, neste sentido, Ihe ser permitida (KELSEN, 2006, p. 273).
} 
não está isenta de críticas. Apesar dos argumentos favoráveis à possibilidade tanto da interpretação restritiva quanto da interpretação restritiva, a sua utilização sempre terá que vir acompanhada de uma justificação. É lícito ir além daquilo que o legislador estabeleceu gramaticalmente?

Essa tese não tem a pretensão de questionar essas premissas; esses questionamentos foram apontados somente para mostrar como as bases da analogia e da interpretação extensiva não estão isentas de críticas. Como o objetivo da tese é investigar a tensão entre a analogia e a interpretação extensiva, essas premissas serão aqui dadas como certas.

Mas, mesmo dando essas premissas como certas, também não é possível deixar de notar que, mesmo diante da unanimidade com a qual a doutrina brasileira trata ambas as técnicas, há outra fragilidade. Uma fragilidade de outra ordem. Essa fragilidade começa a ser desvendada quando se observa que, apesar de todas as distinções apresentadas, é comum encontrarmos sinais de alerta para que o leitor/jurista/estudioso não confunda a analogia e a interpretação extensiva.

A analogia ocupa-se com uma lacuna do Direito Positivo, com hipótese não prevista em dispositivo nenhum, e resolve esta por meio de soluções estabelecidas para casos afins; a interpretação extensiva completa a norma existente, trata de espécie já regulada pelo Código, enquadrada no sentido de um preceito explícito, embora não se compreenda na letra deste. (...) Do exposto já ficou evidente não ser lícito equiparar a analogia à interpretação extensiva (MAXIMILIANO, 2002, p. 175).

Não se deve confundir a analogia com a interpretação extensiva, apesar de, como já assinalamos, esta representar, até certo ponto, uma forma de integração. (...) Podemos dizer que o pressuposto do processo analógico é a existência reconhecida de uma lacuna na lei. Na interpretação extensiva, ao contrário, parte-se da admissão de que a norma existe, sendo suscetível de ser aplicada ao caso, desde que estendido o seu entendimento além do que usualmente se faz (REALE, 2003, p. 297-298). 
O cuidado especial com a interpretação extensiva provoca uma distinção entre esta e a interpretação por analogia. A doutrina afirma que a primeira se limita a incluir no conteúdo da norma um sentido que já estava lá, apenas não havia sido explicitado pelo legislador. Já na segunda, o intérprete toma de uma norma e aplica-a um caso para 0 qual não havia preceito nenhum, pressupondo uma semelhança entre os casos. (...) A distinção, porém, não é rigorosa (FERRAZ JR., 2007, p. 310-311).

A interpretação extensiva dilata o significado até o ponto máximo que o termo permite. Pode ser admitida se o intérprete indicar os motivos pelos quais a interpretação declarativa não corresponde à verdadeira vontade do legislador. Para tanto, o intérprete deve comprovar que o legislador disse menos do que pretendia, devendo o intérprete corrigir esse problema, ajustando a norma às intenções do legislador. (...) No caso da analogia, o intérprete excede o limite do possível significado dos termos legais. A analogia começa onde termina a possibilidade de interpretação extensiva. Temos uma interpretação analógica quando se considera que uma norma rege determinadas situações, apesar da impossibilidade de subsumir essas situações aos termos da norma. A analogia se justifica pela constatação de que os casos contemplados pela norma apresentam grandes semelhanças com os não contemplados (DIMOULIS, 2011, p. 155).

Ainda que sejam técnicas próximas, não se pode confundir a analogia e a interpretação extensiva. A diferença mais elementar é que enquanto na "interpretação extensiva" a discussão se mantém no campo semântico do texto legal existente, no caso da "analogia" não existe disciplina para o caso ao qual se procura solucionar (SGARBI, 2013, p. 145).

Se a distinção entre analogia e interpretação extensiva parece tão simples, qual é o motivo para os constantes sinais de alerta? Essa é uma pergunta legítima porque a doutrina brasileira, apesar de constantemente advertir sobre a proximidade existente entre as duas técnicas, em nenhum momento chega a explicar qual é essa proximidade. Talvez essa proximidade seja auto evidente, de desnecessária explicação. Ou talvez não. Talvez estejamos diante de um tópico que ainda carece de desenvolvimento pela teoria do direito. Será que a distinção entre analogia e interpretação extensiva só parece ser simples? 
Quem se propõe a investigar a analogia e a interpretação extensiva encontra, em um primeiro momento, uma música de uma nota só. Mas, como canta Tom Jobim na música "Samba de uma nota só", a base é uma só, mas outras notas vão entrar. E, enquanto essas notas vão surgindo, é possível escutar, ao fundo, um ruído. Um ruído que, talvez, sempre esteve presente, mas que só agora se faz notar.

Apesar do coro que afirma a distinção entre a analogia e a intepretação extensiva, não existem vozes dissonantes?

Como se verá no próximo capítulo, a resposta é positiva. 


\section{3}

\section{Dois caminhos, mesmo destino: a tensão entre analogia e interpretação extensiva}

Quais são as vozes dissonantes?

Karl Engisch, no livro Introdução ao pensamento jurídico, reafirma a primeira distinção entre analogia e interpretação extensiva apresentada no final do último capítulo: a primeira é técnica de integração, enquanto a segunda é um tipo de interpretação. Como consequência, afirma-se que a interpretação precede a analogia. Nas suas palavras: "De um modo geral podemos dizer: a analogia insere-se por detrás da interpretação, por detrás mesmo da interpretação extensiva. Se, para a interpretação, se assenta na regra de que ela encontra o seu limite lá onde o sentido possível das palavras já não dá cobertura a uma decisão judicial" (ENGISCH, 1996, p. 294). Mas, como o próprio reconhece, "nem sempre é fácil descobrir a correta linha de fronteira entre a interpretação e a analogia". Quando termina o campo da interpretação extensiva e começa a âmbito de atuação da analogia?

Como exemplo, ele cita o § 46 do Código Penal alemão, que prevê a isenção da pena ao agente que espontaneamente desistir da tentativa. Qual é o significado de "agente"? É possível estender o seu campo semântico para incluir, também, o cúmplice? E o mandante do crime? Se a resposta for sim, utiliza-se a interpretação extensiva. Se a resposta for 
não, abre-se caminho para a analogia. Como se vê, não é simples encontrar a linha de fronteira entre as duas técnicas.

É por esse motivo que, após apresentar essas dificuldades, ele arremata: "Seguramente, pois, que a linha limítrofe entre a interpretação (especialmente a interpretação extensiva), por um lado, e a analogia, pelo outro, é fluída" (ENGISCH, 1996, p. 294).

Talvez seja esse o motivo para os constantes sinais de alerta proferidas pela doutrina quando da distinção entre a analogia e a interpretação extensiva: ambas as técnicas são muito próximas, e a linha que demarca o fim de uma e o início da outra é, como aponta, Engisch, de difícil demarcação.

Essa proximidade fica ainda mais visível no livro Direito e Justiça, do jurista dinamarquês Alf Ross. Ao discorrer sobre o conceito de interpretação extensiva, ele acaba utilizando a interpretação analógica como um sinônimo: "Fala-se de interpretação extensiva (interpretação por analogia) quando as considerações pragmáticas se traduzem na aplicação da regra a situações que, contempladas à luz do seu sentido linguístico natural se encontram claramente fora do seu campo de referência” (ROSS, 2000, p. 179). Ao igualar a interpretação extensiva e a interpretação por analogia, Ross demonstra o quanto o ato de estender o campo semântico de uma palavra (possível na interpretação extensiva) deve ao raciocínio analógico. Se, por exemplo, uma norma utilizar o termo "homem", não há razão para não incluir as mulheres no seu âmbito de proteção. E como é possível essa inclusão (ou extensão)? Segundo Ross (2000, p. 180), isso é possível através do raciocínio analógico:

O problema subjacente à interpretação extensiva (interpretação por analogia) pode ser descrito da maneira que se segue. Se segundo seu sentido linguístico natural uma regra se aplica à esfera $A$, sua extensão à esfera $B$ pressupõe:

1) Que atua uma valoração jurídica em favor da aplicação da regra à esfera $\mathrm{B}$. Essa valoração pode fundar-se em particular na concepção de que a regra é uma formulação 
parcial, uma revelação incompleta e esporádica de um ponto de vista mais geral.

2) Que não há diferenças entre $A$ e $B$ que possam justificar o tratamento distinto dos dois casos. Se, por exemplo, uma lei antiga utiliza palavras tais como ele e homem, pode-se sustentar que no direito atual já não subsiste a diferenciação jurídica entre homens e mulheres, e que a lei, portanto, deve estender-se, por analogia, às mulheres.

Karl Engisch e Alf Ross apresentam bons questionamentos, em especial no tocante à fluidez da linha que demarca a aplicação da interpretação extensiva e da analogia. Esses questionamentos, entretanto, são suficientes para rachar o quadro que tão nitidamente separa uma da outra? Ainda não, porque esses questionamentos, apesar de pertinentes, não foram desenvolvidos pelos autores. A fluidez de fronteira ainda parece insuficiente diante de todas as distinções (resumidas nos quatro itens compilados no fim do último capítulo) apontadas pela doutrina.

Apesar de embrionários, esses questionamentos podem mostrar um caminho de investigação - que foi seguido por dois professores italianos.

\section{1}

\section{Traços distintos e comuns}

Damiano Canale e Giovanni Tuzet são professores do Departamento de Estudos Jurídicos da Universidade de Bocconi, em Milão. Em conjunto, publicaram em 2014 o artigo Analogy and Interpretation in Legal Argumentation, em que questionam a diferenciação entre analogia e interpretação extensiva. 
O trecho abaixo resumo todos os argumentos que serão desenvolvidos ao longo do artigo:

O problema é que, na prática, dificilmente se pode distinguir a analogia da interpretação extensiva. Não está muito claro se existe uma diferença real entre os dois e onde pode estar. Por um lado, alguns estudiosos afirmam que diferem de um ponto de vista teórico, uma vez que não possuem a mesma estrutura argumentativa. Por outro lado, raciocínio analógico e interpretação extensiva chegam ao mesmo resultado a partir dos mesmos materiais jurídicos: justificam a extensão de um regulamento a um caso que não é explicitamente considerado pela lei (CANALE e TUZET, 2014, p. 228).

Há, em primeiro lugar, ecos dos questionamentos de Karl Engisch e Alf Ross: tendo em vista a fluidez da linha limítrofe entre a analogia e a interpretação extensiva, o resultado é que, na prática, é muito difícil diferenciar uma da outra.

Em segundo lugar, apesar de todas as diferenças apontadas pela doutrina, Canale e Tuzet apresentam um ponto de semelhança: ambas são utilizadas quando a norma não dá uma solução clara e simples para o caso em debate. Pois, se a lei confere uma rápida resposta para um determinado caso, não será necessário o recurso a outro tipo de interpretação ou a qualquer técnica de integração - basta a interpretação literal. Tanto a analogia quanto a interpretação extensiva, apesar da diferença na estrutura do argumento, irão justificar a extensão da norma para abarcar uma situação que não seria possível através de uma interpretação literal.

E, por fim, a constatação de que é possível alcançar o mesmo resultado tanto com a analogia quanto com a interpretação extensiva. Elas servem ao mesmo propósito. ${ }^{12}$

Os autores utilizam dois exemplos para expor os argumentos acima.

${ }^{12}$ Esse ponto também é levantado por Wróblewski (1992, p. 226). 
O primeiro é o caso da rádio do Vaticano. Segundo as denúncias, as torres de transmissão da rádio do Vaticano emitem ondas eletromagnéticas que ameaçam a saúde daqueles que moram nas proximidades. O que estava em discussão nesse caso: primeiro, se as emissões estavam dentro dos limites ambientais estabelecidos pela lei administrativa italiana e, segundo, se era um caso de natureza criminal.

Não há, no Código Penal italiano, qualquer menção a ondas eletromagnéticas. Mas o artigo $674^{13}$ prevê sanções para o "arremesso perigoso de coisas". Estariam as ondas eletromagnéticas proibidas em razão do disposto no artigo 674 ?

Em questão, dois problemas interpretativos: "(1) o significado de 'arremesso' e (2) o significado de 'coisas'. Uma emissão é um ato de 'arremesso' de acordo com a lei? As ondas são 'coisas' de acordo com a lei? E, em conjunto, o ato de emitir tais ondas é um 'arremesso perigoso de coisas'?" (CANALE e TUZET, 2014, p. 234).

Seria esse um caso de lacuna jurídica?

Se a resposta for não, então a discussão girará em torno da possibilidade interpretação extensiva: é possível ampliar o significado do termo "arremesso perigoso de coisas" para englobar a emissão de ondas eletromagnéticas?

Se a resposta for sim, então a discussão girará em torno da possibilidade da analogia: é possível regular o caso da rádio do Vaticano da mesma forma que o Código Penal regula o "arremesso perigoso de coisas"?

E o mais interessante para o argumento que Canale e Tuzet querem sustentar: independente da técnica utilizada, o jurista consegue

\footnotetext{
${ }^{13}$ Art. 674 do Código Penal italiano - Arremesso perigoso de coisas. Quem joga ou derrama, em um local de transporte público ou em local privado, mas de uso comum, coisas adequadas para ofender ou sujar ou assediar pessoas, ou, em casos não permitidos por lei, causa emissões de gás, vapores ou de fumaça, suscetível de causar esses efeitos, é punido com prisão de até um mês ou multa.
} 
alcançar a mesma solução tanto pela analogia quanto pela interpretação extensiva. A estrutura do argumento será diferente, mas o resultado poderá ser o mesmo.

Já o segundo caso que os autores utilizam envolve a regra hipotética mais famosa ${ }^{14}$ da teoria e da filosofia do direito: "é proibida a entrada de veículos no parque".

\section{2}

\section{Os veículos no parque}

É possível conhecer todos os significados atribuídos a uma palavra?

Todos sabem (mesmo que seja tão somente no nível intuitivo) que as palavras possuem vários significados. ${ }^{15}$ Ao ler a palavra "manga", o leitor pode pensar na fruta ou na parte da roupa que cobre o braço. Mas a pergunta é mais ampla. É possível conhecer todos os significados que uma palavra pode ter?

Na história dos dicionários, não há nada que se equipare ao projeto do Oxford English Dictionary. Ao contrário da maioria dos dicionários disponíveis, ele não foi escrito por uma única pessoa, mas por uma

\footnotetext{
14 "É o exemplo hipotético mais famoso do universo da common law. E faz parte de um dos debates mais memoráveis da teoria do direito" (SCHAUER, 2008, p. 1109).

${ }^{15}$ Hans Kelsen, ao discorrer sobre a indeterminação do direito, já apontava para o fenômeno da pluralidade dos significados das palavras: "Simplesmente, a indeterminação do ato jurídico pode também ser a consequência não intencional da própria constituição da norma jurídica que deve ser aplicada pelo ato em questão. Aqui temos em primeira linha a pluralidade de significações de uma palavra ou de uma sequência de palavras em que a norma se exprime: o sentido vernal da norma não é unívoco, o órgão que tem de aplicar a norma encontra-se perante várias significações" (KELSEN, 2006, p. 389).
} 
comissão que, com o propósito de compor o maior e melhor dicionário da língua inglesa, publicou anúncios e enviou correspondências para todo o império britânico (e demais localidade que falavam a língua inglesa) pedindo para que as pessoas enviassem usos específicos e incomuns de palavras que só elas conheciam; e tudo isso em um período pré-internet. Foram décadas coletando essas informações, montando todo o universo de uso da língua inglesa. ${ }^{16}$ A primeira edição foi publicada em 1884; a segunda edição (que totaliza 21.730 páginas divididas em vinte volumes) foi publicada 1989.

Infelizmente não existe um empreendimento como esse em cada língua falada no mundo. Mas, se imaginarmos um futuro no qual para cada língua existisse um dicionário como esse, que passasse décadas coletando todos os usos possíveis e incomuns de todas as palavras, a resposta para a pergunta acima poderia ser sim: nesse caso, conseguiríamos conhecer todos os significados atribuídos a uma determinada palavra.

Entretanto, o empreendimento do Oxford English Dictionary, ao invés de servir como argumento a favor da onisciência da linguagem, acabou comprovando a impossibilidade de conhecermos todos os significados das palavras. Isso porque esse empreendimento, que começou há mais de século, ainda não terminou. O Oxford English Dictionary é um projeto em andamento, e que nunca chegará a termo. Como o seu volume só cresce (com o número de entradas e atribuições de novos significados aumentando a cada ano), o dicionário deixou de ser vendido em formato físico. Hoje, ele só está disponível em versão

\footnotetext{
${ }^{16}$ A história de amor para com a língua que é o Oxford English Dictionary foi contada pelo professor e tradutor Caetano Waldrigues Galindo na mesa de debates intitulada "Homero, Euclides da Cunha e James Joyce por seus tradutores", realizada no dia 27 de agosto de 2014 no Salão de Ideias da Bienal do Livro de São Paulo. A gravação está disponível no YouTube: https://www.youtube.com/watch?v=iYP4sINM604. Acesso em: 05 dez. 2020. Outras fontes importantes sobre a história do Oxford English Dictionary são os livros The Surgeon of Crowthorne: A Tale of Murder, Madness and the Love of Words (1999) e The Meaning of Everything - The Story of the Oxford English Dictionary (2004), ambos do escritor e jornalista Simon Winchester.
} 
online ${ }^{17}$, e, para ter acesso, é necessário pagar uma assinatura. (Ele não pode ser "comprado" porque isso passaria a ideia de completude; dada a sua permanente atualização, só é possível assiná-lo.)

A impossibilidade de se conhecer todos os significados das palavras é, na realidade, uma característica da linguagem. Em um artigo publicado em 1945, o filósofo Friedrich Waismann cunhou o termo "textura aberta" para se referir a essa característica.

Segundo ele, qualquer tentativa de esgotar o conceito de uma palavra irá fracassar graças à textura aberta da linguagem. Se a linguagem tivesse uma textura fechada, seria possível visualizar um conjunto (fechado) com todos os significados de uma palavra; se assim o fosse, seria possível conhecer todos os significados de uma palavra, pois, sendo esse conjunto um conjunto fechado, tornar-se-ia impossível a retirada de significados não mais em uso ou a inclusão de novos significados. Isso, porém, é impossível. Os conceitos são porosos.

Cada definição (empírica) se expande em um horizonte aberto. (...) Nenhuma definição de um termo empírico cobrirá todas as possibilidades. $\mathrm{O}$ resultado, então, é que a incompletude da nossa verificação está enraizada na incompletude da definição dos termos envolvidos, e a incompletude da definição está enraizada na incompletude da descrição empírica (WAISMANN, 1945, p. 126).

A palavra "mão", por exemplo. Poderíamos começar a tarefa de conceituar essa palavra encontrando os diferentes usos e significados que ela possui. A minha mão direita está coçando (parte dos membros superiores do corpo humano que vai dos punhos até a extremidade dos dedos); o dinheiro caiu nas mãos erradas (posse ou propriedade); ele tem uma mão boa para a marcenaria (destreza, habilidade); a decisão está em suas mãos (poder ou autoridade); a minha mão no pôquer era boa (jogo de cartas)... Seria possível esgotar esses usos e significados? Não, nem mesmo com todos os Oxford English Dictionary disponíveis, porque,

${ }^{17}$ Na página inicial (oed.com) lê-se: "Descubra a história do inglês. Mais de 600.000 palavras, ao longo de mil anos". 
pois mais que consigamos, através de um esforço hercúleo, conhecer todos os usos e significados utilizado hoje e agora, nunca seremos capazes de conhecer aqueles que surgirão no futuro.

A característica da textura aberta da linguagem realça o fato de que o campo de significados de uma palavra é sempre aberto, possibilitando a retirada e inclusão de significados. A palavra "nuvem" é um exemplo. Uma pessoa em 1990 que tentasse conhecer todos os significados dessa palavra nunca conseguiria alcançar esse objetivo, pois a computação em nuvem ainda estava para ser inventada. ${ }^{18}$

É importante observar que a textura aberta da linguagem não se confunde com a vagueza. Na famosa acepção de Paul Grice, "dizer que uma expressão é vaga (em sentido amplo) é, grosso modo, presumivelmente dizer que há casos (atuais ou possíveis) em que não se sabe se uma expressão se aplica ou não, e não saber se não deve apenas a ignorância dos fatos" (1989c, p. 177). Na vagueza, a extensão dos termos não é clara, no sentido de que surgirão casos de fronteira que colocarão em dúvida a incidência ou não da expressão a determinado caso.

A palavra "rico", por exemplo. Esse é um termo vago porque, apesar da existência de zonas de aplicação e de não aplicação bem delimitadas (um milionário se encaixa nessa palavra, enquanto uma pessoa em estado de miserabilidade não), também existe uma zona de dúvida (ENDICOTT, 2000, p. 31-33). Qual é a linha que separa o rico do não-rico? Essa linha é demarcada somente pelo aspecto patrimonial (posse de bens materiais) ou também pode ser considerada a abundância

\footnotetext{
18 Uma história real. Uma neta mostra para a sua avó as fotos e vídeos feitas pelo celular de uma festa que ambas foram na noite anterior. A avó fica maravilhada. Ela tem 86 anos; é uma imigrante portuguesa, que veio para o Brasil em uma viagem a barco que durou 8 dias e que a deixou com um pavor incorrigível do oceano. Seu contato com a tecnologia se limita à assistir televisão e falar ao telefone fixo. Quando ela pergunta à neta como é possível um aparelhinho tão pequeno guardar tantas fotos e vídeos, a neta inocentemente responde: "É fácil, vó. Está tudo na nuvem". Espantada, a avó vai até a janela e olha para o céu, procurando.
} 
de outros valores (como quando uma pessoa diz que é rica em amizades)?

A existência de zonas de aplicação/não-aplicação e zonas de dúvidas é recorrente nos termos vago. Outro exemplo é a palavra "calvo". Inicialmente entendido como a ausência de cabelos na cabeça, facilmente incluímos uma pessoa careca no conceito de calvo, enquanto excluímos aquela que ostenta uma lustrosa cabeleira. Mas o que dizer daquela pessoa que possui pouquíssimo cabelo? Ela poderia ser considerada como calva?

Entendida nesses termos, a vagueza não se confunde com a textura aberta da linguagem. A textura aberta está, é razoável afirmar, um grau acima da vagueza. Como sustenta Frederick Schauer: "Vale ressaltar que 'textura aberta' não é a mesma coisa que vagueza, mas é característica de qualquer idioma, mesmo o mais preciso, para se tornar vago diante de aplicações imprevistas. A textura aberta não é vagueza, mas a possibilidade onipresente de vagueza" (2009, p. 163).

Mas a possibilidade onipresente de vagueza. Essa frase resume perfeitamente a ideia da textura aberta da linguagem. Mesmo a mais precisa das palavras é potencialmente imprecisa. Ela pode ser clara e precisa hoje, mas, graças à textura aberta, novos significados podem surgir e/ou novas situações não antes previstas podem acontecer, criando assim zonas de dúvidas que não existiam. Ou seja, a textura aberta é uma característica da linguagem como um todo: mesmo a palavra mais precisa possui uma textura aberta - pois sempre há a possibilidade onipresente de vagueza.

E o direito? Qual o impacto dessa característica da linguagem para a interpretação das normas jurídicas?

Essas respostas são fornecidas por Herbert L. A. Hart, que aproveitou essa contribuição da filosofia da linguagem para tecer as suas contribuições para a teoria/filosofia do direito, desenvolvidas no sétimo capítulo do seu livro O Conceito de Direito. 
Hart começa o capítulo afirmando uma característica das normas jurídicas: o uso de uma linguagem geral. ${ }^{19}$ Essa característica é essencial para o direito. "Se não fosse possível transmitir, sem nenhuma orientação adicional, padrões gerais de conduta compreensíveis para multidões de indivíduos, não existiria nada do que hoje entendemos por direito" (HART, 2009 , p. 161). Seria impossível, para o direito, regular a conduta humana através de orientações específicas transmitidas a cada indivíduo - são muitas pessoas, muitas situações, muitas possibilidades. Por esse motivo, a linguagem utilizada pelo legislador é geral - ele irá se referir à classe de pessoas e classes de palavras. Quando o artigo 121 do Código Penal estabelece "Matar alguém: Pena - reclusão, de seis a vinte anos", a quem é dirigida a proibição do homicídio? Todas as pessoas. Quando o artigo 22 do Código de Ética e Disciplina da OAB dispõe que "o advogado não é obrigado a aceitar a imposição de seu cliente que pretenda ver com ele atuando outros advogados", quais são os advogados por ele protegidos? Todos os advogados. Quando o artigo o caput do artigo 84 da Constituição Federal lista o que "compete privativamente ao Presidente da República", a referência não é a um Presidente em específico, mas sim àquele que ocupa essa função. A linguagem utilizada pelo direito possui um aspecto generalizador, fazendo referência à classe de pessoas e classe de palavras.$^{20} \mathrm{E}$ a própria possibilidade do direito decorre da nossa capacidade de reconhecer certos atos como inseridos nas cláusulas gerais previstas pelas normas jurídicas. Como quando um sujeito toma posse de um imóvel, ainda que de má-fé, nele permanecendo por quinze anos de forma mansa, pacífica e ininterrupta: o jurista possui a capacidade de perceber que essa situação específica está

${ }^{19}$ Essa generalidade da língua pode ser observada nos elementos formadores das normas jurídicas prescritivas, especialmente no 'sujeito normativo' (termo que designa os destinatários das normas). Georg von Wright utiliza o termo "destinatários gerais das normas" (1963, p. 121-125); segundo ele, as normas podem ser classificadas como "particulares", quando se dirige a agentes específicos, ou "gerais", quando dirigidas a uma classe de agentes. Nesse sentido, ver também Sgarbi (2007, p. 128).

${ }^{20}$ Mas, como o próprio Hart admite ("em consequência, o direito deve referir-se preferencialmente, embora não exclusivamente, a classes de pessoas e a classes de condutas" (HART, 2009, p. 161)), há situações em que o direito irá se dirigir especificamente a uma determinada pessoa. Seria a situação, por exemplo, em uma sentença prolatada por juiz. 
inserida dentro da norma geral prevista pelo artigo 1.238 do Código Civil, que disciplina a usucapião extraordinária.

E é nessa análise de inserção do caso concreto na norma geral que Hart demonstra o impacto da textura aberta da linguagem para 0 direito, pois "mesmo quando se utilizam normas gerais formuladas verbalmente, podem surgir, em casos concretos específicos, incertezas quanto ao tipo de comportamento por elas exigido" (HART, 2009, p. 163).

Em outras palavras: o surgimento de casos limítrofes, em que não saberemos se estão inseridos na previsão geral da norma, é sempre uma possibilidade.

O artigo 150, VI, 'd' da Constituição Federal é um excelente exemplo da potencialidade da textura aberta para o direito. Ele dispõe que é vedada aos entes federativos a instituição de impostos sobre "livros, jornais, periódicos e o papel destinado a sua impressão". O que é "livro"? Em uma primeira interpretação, literal, pode-se compreender livro como sendo tão somente o livro físico, uma coleção de folhas de papel. (E o trecho "e o papel destinado a sua impressão" parece dar azo a essa interpretação.) Porém, no final da década de 90 e início dos anos $2000^{21}$, começa a surgir um questionamento na doutrina e jurisprudência brasileira: os "livros eletrônicos" também possuem imunidade tributária? Em outras palavras: os "livros eletrônicos" estão inseridos na classe "livros" contida no artigo 150, VI, 'd' da Constituição Federal?

A resposta não é simples. Conforme demonstra Humberto Ávila (2001, p. 158-159), é possível encontrar, tanto na doutrina quanto na jurisprudência, argumentos favoráveis e contra. Entre os argumentos favoráveis à imunidade tributária dos "livros eletrônicos", estão: "o livro eletrônico é uma espécie de livro"; "ele é um meio, como o livro, para garantir a liberdade de expressão e de informação"; "o livro eletrônico significaria, hoje, aquilo que o livro representou ontem". E, entre os argumentos contrários: "a expressão 'e o papel destinado a sua

${ }^{21}$ Ver, nesse sentido, MACHADO (1998) e ÁVILA (2001). 
impressão' afastaria qualquer objeto que não fosse feito de papel"; "os tribunais brasileiros já se posicionaram no sentido de só haver livro aonde há papel"; "a não tributação dos livros eletrônicos traria uma perde significativa de receita para o Estado".

Esse questionamento, dada a sua dificuldade, foi objeto de inúmeras ações no judiciário brasileiro, e o Supremo Tribunal Federal só proferiu decisão sobre o caso em 2017. Ao julgar os Recursos Extraordinários 330.817 e 595.676, a corte decidiu no sentido de garantir a imunidade tributária dos livros eletrônicos. Em seu voto, o relator Ministro Dias Toffoli argumentou através da ratio legis e de considerações sobre a evolução da consciência jurídica e social: "as mudanças históricas e os fatores políticos e sociais presentes na atualidade, seja em razão do avanço tecnológico, seja em decorrência da preocupação ambiental, justificam a equiparação do papel aos suportes utilizados para a publicação dos livros". ${ }^{22}$ Segundo ele, a finalidade da norma constitucional que garantiu a imunidade tributária aos livros foi a de efetivar a liberdade de expressão, protegendo os veículos de ideias e de transmissão de pensamentos - classe essa que inclui os livros eletrônicos.

Mas os problemas não se esgotaram. Eles podem ter sido solucionados por hora, mas, graças à textura aberta da linguagem, novas situações que ainda nem podemos imaginar irão surgir no futuro, e o mesmo questionamento irá reaparecer - só que com outra roupagem. ${ }^{23}$ Pois, no futuro, novas tecnologias irão surgir, e, junto com elas, o questionamento: isso pode ser considerado como um livro? Há um século, ninguém pensava na possibilidade de ler um livro no celular; como saber o que será considerado como livro daqui a um século? Como dito

\footnotetext{
22 Íntegra do voto disponível em: https://bit.ly/34jKPHu. Acesso em: 05 dez. 2020. ${ }^{23} \mathrm{Um}$ exemplo da ficção cientifica para ilustrar o argumento: o filme Matrix (1999) apresenta um futuro despótico no qual os seres humanos possuem algo como uma entrada de USB na nuca, e inúmeros conhecimentos (desde técnicas de luta e uso de armas até as informações e habilidades necessárias para pilotar um helicóptero) são transmitidos, em segundos, após um cabo ser acoplado nessa entrada. Se um dia essa tecnologia se tornar realidade, ela será considerada como "livro" nos termos do artigo 150, VI, 'd' da Constituição Federal - e, estará, consequentemente, protegida pela imunidade tributária?
} 
acima, a textura aberta da linguagem não se confunde com a vagueza; ela é possibilidade onipresente de vagueza.

Ao discorrer sobre a textura aberta da linguagem, Hart utiliza um exemplo simples, mas ao mesmo tempo extremamente poderoso na sua força expositiva. A famosa frase de José Ortega y Gasset "a clareza é a cortesia do filósofo" (2016, p. 19) se encaixa perfeitamente aqui. O exemplo é a regra hipotética "é proibida a entrada de veículos no parque" (HART, 2009, p. 164-166).

A indeterminação dessa regra surge da indeterminação da palavra "veículo". O que é um veículo? Há situações em que não pairam dúvidas; seria o caso de um carro, de uma moto, de um caminhão. Mas há situações limítrofes, nas quais o intérprete ficará em dúvida sobre a aplicação. Uma bicicleta pode ser considerada como um veículo para os fins dessa regra? E um skate? Um patinete?

Qualquer um que já tenha discutido essa regra com um grupo de pessoas (seja um professor dando aula para o seus alunos ou alguém conversando com os amigos em uma mesa de bar) sabe que as respostas nunca são unânimes: há aqueles que proibiriam a entrada de um skate no parque e aqueles que permitiriam a sua entrada. $E$ há aqueles que problematizam a questão ainda mais: $E$ uma ambulância? $E$ um carro transportando uma pessoa acidentada que precisa ser levada com urgência ao hospital? E uma bicicleta motorizada? Os questionamentos são infinitos, ao ponto de alguém afirmar que proibiria tudo isso, inclusive a entrada de jornais no parque (veículo de comunicação).

Por mais que os interpretes queiram determinar um conceito para a palavra "veículos", as situações limítrofes não cessarão, e o intérprete se pegará tendo que rever o conceito que acabou de determinar. Veículo é qualquer meio de transporte utilizado para conduzir pessoas de um lugar para o outro: então a entrada de um carrinho de bebê será proibida? Veículo é qualquer meio de transporte motorizado utilizado para conduzir 
pessoas de um lugar para o outro: então a entrada de um deficiente físico em uma scotter elétrica será proibida? (É como afirmado por Waismann em citação já transcrita acima: "Cada definição se expande em um horizonte aberto... Nenhuma definição de um termo empírico cobrirá todas as possibilidades.") $)^{24}$

É possível escapar à textura aberta da linguagem? Não. Ela é uma característica inerente à linguagem. Mesmo a norma jurídica mais precisa é potencialmente imprecisa. E por mais que o intérprete tente delimitar todas as hipóteses de incidência da norma, ele nunca conseguirá esgotar todas as hipóteses, porque, como afirmou Hart, "somos homens, e não deuses. (...) Se o mundo no qual vivemos tivesse apenas um número finito de características, e estas fossem conhecidas por nós, poderíamos então prever de antemão todas as possibilidades" (2009, p. 166).

Quem já assistiu ao filme De volta para o futuro 2 não esquece da cena em que o personagem principal, Marty McFly, pega uma prancha flutuante e consegue fugir das pessoas que o perseguia. $E$ não há adolescente que não tenha assistido ao filme durante a adolescência que não sonhou com essa prancha flutuante. Se um dia ela virar realidade, será considerado veículo? Sua entrada no parque será proibida? E o que se dirá das novas tecnologias de locomoção que ainda serão inventadas? Essa é a força da textura aberta da linguagem.

Diante de uma situação como essa, como o jurista deve proceder? Segundo Hart, ele deverá fazer uma escolha: "a discricionariedade que a norma the confere pode ser muito ampla, de tal forma que a decisão, embora não seja arbitrária ou irracional, será de fato resultante de uma

\footnotetext{
${ }^{24}$ É o que Waismann irá chamar de "incompletude essencial". "A impossibilidade das nossas descrições empíricas impossibilita a descrição do conjunto total de situações em que uma palavra se aplica ou não. Isso significa que a incompletude essencial das nossas descrições empíricas é responsável pela incompletude da definição dos nossos conceitos empíricos ou pela textura aberta desses conceitos. Portanto, por mais que possamos tentar construir uma definição ou modelo de pensamento capaz de antecipar todos os usos dos conceitos empíricos, essa tarefa é impossível já que sempre podem surgir casos novos que requeiram uma reformulação da definição" (STRUCHINER, 2002, p. 26).
} 
escolha" (HART, 2009, p. 164). E, se essa escolha não é arbitrária ou irracional, quais critérios irão balizá-la? Buscando semelhanças.

Indagada se a norma que proíbe o uso de veículos no parque é aplicável a algum conjunto e circunstâncias no qual tal aplicação parece incerta, a pessoa encarregada de responder não tem outra alternativa senão a de examinar se 0 caso presente se assemelha 'suficientemente' ao caso simples sob os aspectos 'pertinentes'.

\section{(...)}

A pessoa decide acrescentar um caso novo a uma sucessão de outros, devido a semelhanças que podem ser razoavelmente consideradas pertinentes do ponto de vista jurídico e suficiente próximas do ponto de vista factual. No caso das normas jurídicas, os critérios de pertinência e a proximidade por semelhança dependem de muitos fatores complexos, integrados no sistema jurídico, e dos objetivos ou do propósito que podem ser atribuídos à norma (HART, 2009, p. 164-165).

Pelo exposto, a afirmação de que a regra que proíbe a entrada de veículos no parque é um dos exemplos hipotéticos mais famosos da teoria e da filosofia do direito não parece uma hipérbole mal pensada. Ela explica uma das fontes para a indeterminação do direito; apresenta desafios para a interpretação e a aplicação do direito; aponta novos caminhos a serem investigados. E, além de tudo isso, ela ainda pode ser utilizada para demonstrar que a analogia e a interpretação extensiva podem alcançar o mesmo resultado.

\section{3}

\section{O mesmo resultado}

Além do caso da rádio do Vaticano, Damiano Canale e Giovanni Tuzet também utilizam a regra que proíbe a entrada de veículos no parque para sustentar o argumento de que a analogia e a interpretação extensiva podem ser utilizadas para alcançar o mesmo resultado. 
O argumento é desenvolvido através da seguinte linha de raciocínio (CANALE e TUZET, 2014, p. 232-233). Imagine um intérprete que, diante da regra "é proibida a entrada de veículos no parque", interprete a palavra "veículo" como sendo tão somente meio de transporte motorizado utilizado para conduzir pessoas de um lugar para o outro - e que, por esse motivo, não consideraria um skate como um veículo. Mas, mesmo não considerando skate como um veículo, seria possível proibir a entrada do skate com base nessa regra? Em outras palavras: é possível ampliar o campo semântico dessa regra de modo a englobar também o skate?

Sim - e é possível justificar essa resposta tanto pela interpretação extensiva quanto pela analogia, já que ambas permitem a expansão da norma para, assim, abarcar uma situação (skate) que não está enquadrada por sua interpretação literal (meios de transporte motorizado). Serão duas estruturas de argumentação, mas o resultado poderá ser o mesmo.

$\mathrm{Na}$ primeira, há um juiz que interpreta a palavra veículo como significando "meio de transporte motorizado". Mas ele vislumbra a possibilidade de ampliar esse significado para abarcar outras situações, por entender que o legislador disse menos do que gostaria de ter dito e porque o campo semântico da palavra permite essa extensão. Nesse sentido, ele proibirá a entrada do skate no parque, e justificará essa decisão através de uma interpretação extensiva.

Na segunda, há um juiz que interpreta a palavra veículo como significando tão somente "meio de transporte motorizado", e nada mais. Ele não vislumbra a possibilidade de ampliar esse significado. Logo, a situação que ora se apresenta (é permita a entrada de skates no parque?) se traduz em uma lacuna jurídica. Diante dessa lacuna, o juiz poderá integrar o ordenamento jurídico através da analogia. Seu argumento se dará nesse sentido: a regra proíbe a entrada de veículos no parque; skate não é um veículo; mas um skate é semelhante a um veículo, tendo em vista que ambos são meios de transporte e que podem causar riscos aos 
frequentadores do parque; logo, o mesmo tratamento dispensado aos veículos deve ser estendido também para o skate. Nessa segunda situação, o juiz proibirá a entrada do skate no parque, e justificará sua decisão através da analogia.

Se a analogia e a interpretação extensiva podem levar ao mesmo resultado, há de se perguntar se essa distinção ainda se justifica. Para o pragmatismo filosófico, que é uma abordagem para as questões filosóficas que foca nas consequências práticas dos conceitos aplicados ${ }^{25}$, não existiria razões para sustentar a diferença entre elas.

Entretanto, há um desafio ainda mais urgente que requer uma análise mais detida da distinção (ou não) entre a analogia e a interpretação extensiva, e esse desafio vêm do direito penal e do princípio da legalidade.

O ruído se intensifica.

\footnotetext{
${ }^{25}$ Um dos principais nomes do pragmatismo norte-americano, Charles Sanders Pierce, expõe a máxima pragmática nos seguintes termos: "Considere que efeitos, que podem ter orientações práticas, imaginamos ter o objeto de nossa concepção. Então nossa concepção desses efeitos é a totalidade de nossa concepção do objeto" (1878, p. 293).
} 
4

\section{Uma casa, dois endereços: analogia e interpretação extensiva frente ao princípio da legalidade}

$\mathrm{O}$ artigo $3^{\circ}$ do Código de Processo Penal estabelece que "a lei processual penal admitirá interpretação extensiva e aplicação analógica, bem como o suplemento dos princípios gerais do direito".

De acordo com Renato Brasileiro de Lima (2017, p. 100), a pretensão do legislador com o referido artigo foi a delimitar a distinção entre o direito penal e o direito processual penal: enquanto este permite a utilização tanto da analogia quanto da interpretação extensiva (seja a favor ou contra o réu), o direito penal não admite o uso da analogia.

Nesse sentido, o direito penal proíbe a aplicação, por meio da analogia, do dano qualificado previsto no artigo 163, § único, III do Código Penal (redação original quando da promulgação do Código Penal: "Se o crime é cometido contra o patrimônio da União, de Estado ou de Município para as hipóteses de dano em detrimento da Caixa Econômica Federal, que é uma espécie de empresa pública federal.

Mas o uso da interpretação extensiva é permitido. O artigo 157 , § $2^{\circ}$, I do Código Penal previa, originariamente, o aumento da pena para o crime de roubo "se a violência ou ameaça é exercida com emprego de arma". Durante anos a doutrina e a jurisprudência entenderam que a palavra "arma" não deveria ser interpretada como sendo tão somente 
"arma de fogo", devendo ser compreendida também a arma de brinquedo, já que a finalidade de ambas é a mesma - intimidar a vítima. Havia, inclusive, súmula do Superior Tribunal de Justiça nesse sentido: a Súmula 174 - no crime de roubo, a intimidação feita com arma de brinquedo autoriza o aumento da pena. Posteriormente, essa súmula foi cancelada; e uma alteração legislativa aprovada em 2018 deu uma nova redação ao artigo $157, \S 2^{\circ}$, I: "se a violência ou ameaça é exercida com emprego de arma de fogo".

Qual é a razão para a permissão da interpretação extensiva e a proibição da analogia? O princípio da legalidade.

\section{1}

\section{O princípio da legalidade}

O princípio da legalidade está previsto no artigo $5^{\circ}, \operatorname{XXXIX~da~}$ Constituição Federal e no artigo $1^{\circ}$ do Código penal: "não há crime sem lei anterior que o defina, nem pena sem prévia cominação legal".

O direito exerce inúmeras funções: facilitar o acordo privado entre indivíduos, garantir a prestação de serviços e redistribuição de bens, resolver disputas, entre outras (RAZ, 1979, p. 168-175). Mas, dentre todas as funções que o direito exerce, há uma que é de especial importância; durante séculos foi uma função do direito, continua sendo ainda hoje, e continuará a ser nos anos que virão: a regulação da conduta humana, estabelecendo as condutas que são obrigatórias, proibidas e permitidas.

Hans Kelsen (2000, p. 21) identificava o direito como uma técnica social específica (de regulação de conduta). A regulação da conduta 
humana é uma das principais funções do direito, e sua eficácia nesse quesito se faz necessária. Sempre que alguém quer regular a conduta de uma pessoa - sempre que alguém quiser que uma pessoa se comporte de forma distinta da forma como normalmente atua -, a maior forma de garantir conformidade é oferecendo alguma motivação. Se um professor quer que seus alunos leiam duzentas páginas escritas por Kelsen para serem discutidas na aula da próxima semana, quantos alunos irão efetivamente ler? Poucos. Mas, se o professor realmente quiser ser efetivo, nada como a promessa de pontuação extra. $O$ aluno que ler as duzentas páginas, escrever um resumo e participar ativamente das discussões na próxima aula irá ganhar 50 pontos extras no semestre. Diante de tal promessa, qual aluno não irá cancelar a agenda do final da semana para ler Kelsen? (Essa pode não ser a melhor solução do ponto de vista pedagógico, mas provavelmente será a mais eficiente.)

Kelsen classificava as motivações em duas: as diretas e as indiretas. Uma motivação indireta ocorre quando existe uma promessa de recompensa ou uma ameaça de punição em caso de conformidade à conduta exigida. Ela é "indireta" porque o sujeito não obedece porque, para ele, a conduta não é em si própria boa e justificável; ele age em conformidade ao que the foi exigido porque espera algo externo à conduta: ou ele espera receber a recompensa prometida ou espera escapar da punição ameaçada. Já a motivação direta ocorre quando não há a promessa de recompensa ou a ameaça de punição; a conduta por si só já é boa e justificável. Entre as duas motivações, a mais eficaz é a indireta. Segundo Kelsen, "esse tipo de motivação direta, em sua pureza absoluta, raramente é encontrada na realidade social" (2000, p. 22). Se uma mãe quer que o filho coma toda a comida que lhe é oferecida no almoço, ela pode the prometer uma recompensa (sorvete) ou uma punição (ficar sem o celular). $O$ direito, em sua função de regular a conduta em sociedade, atua da mesma forma: prometendo recompensas ou ameaçando com punições. Daí a afirmação de Kelsen no sentido de que o direito é uma ordem coercitiva (2000, p. 27). O direito não exclui a utilização da força, mas a autoriza (SGARBI, 2019, p. 57). 
$\mathrm{E}$, dentre os meios que dispõe o Estado para garantir a observância de suas normas, não há meio coercitivo mais importante, severo e violento do que o direito penal (PELUSO, 2016, p. 174). Por esse motivo, é de fundamental importância estabelecer limites para o uso punitivo do Estado, excluindo assim qualquer possibilidade de arbitrariedade.

O princípio da legalidade é um desses limites.

Normalmente acompanhada pelo termo em latim nullum crimen, nulla poena sine lege (nenhum crime, nenhuma punição sem lei), a explicação do princípio da legalidade destaca que, dentre todas as fontes do direito, os preceitos incriminadores só podem ser definidos por lei - e que, consequentemente, cabe ao juiz a aplicação estrita da norma jurídica, sendo-lhe proibido ir além daquilo que foi legalmente imposto (CASTANHEIRA NEVES, 1995, p. 386).

Esse princípio, entretanto, é mais complexo do que aparenta em um primeiro momento. Conforme apontam Carlos Alchourrón e Eugenio Bulygin (2015, p. 198-199), é difícil determinar o seu conteúdo e funcionamento. Isso se dá em razão das várias funções que ele desempenha e das regras complementares que lhe são decorrentes:

(i) O princípio da legalidade fornece duas diretivas ao legislador. A primeira diretiva exige que os delitos penais sejam definidos com a máxima precisão. Esse é o princípio da tipicidade, que requer que $o$ ato praticado pelo agente esteja inserido na moldura descrita pela lei. E a segunda diretiva requer que o legislador não puna atos que foram realizados antes da criação da lei. Esse é o princípio da irretroatividade da lei penal. ${ }^{26}$

(ii) O princípio da legalidade fornece uma diretiva para os juízes: não decretar sanções se não há norma anterior que

${ }^{26}$ Prevista, no direito brasileiro, no artigo $5^{\circ}, \mathrm{XL}$ da Constituição Federal: "a lei penal não retroagirá, salvo para beneficiar o réu". 
qualifique a conduta cometida como um delito. Corolário dessa diretiva é a proibição da analogia, pois, nessa técnica, é atribuído a um caso não regulado pelo direito o mesmo tratamento conferido a outro caso semelhante. Como se diz, na analogia ocorre a criação de uma nova norma para regular o caso omisso.

Se não há crime sem lei anterior o defina, o uso da analogia é proibido porque o julgador não pode punir o agente através da "criação" de uma nova norma. Mas, por outro lado, a utilização da interpretação extensiva é permitida, pois, nela, não há a criação de uma nova norma, mas tão somente a expansão do significado de uma norma já existente.

Castanheira Neves explica esse tratamento distinto da seguinte forma:

Deste modo o corolário da lex stricta implicará a não aplicação da norma legal incriminadora e punitiva para além do que haja de considerar-se sua aplicação directa ou imediata, possibilitada pela interpretação, e infere-se daí a recusa da sua aplicação indirecta e mediatizada por um autónomo juízo normativo do julgador a casos diferentes, posto que análogos daqueles por ela directamente previstos - que tanto é dizer, recusa-se uma sua aplicação analógica (1995, p. 386).

Ou seja: em razão do princípio da legalidade, o direito penal não admite qualquer forma de ampliação dos preceitos legais para englobar casos omissos.

É por esse motivo que se afirma, no direito penal, a inexistência de lacunas jurídicas. Graças ao princípio da legalidade e a consequente proibição da analogia, afirma-se a completude do direito penal, estando penalmente permitido o que não está penalmente proibido. $O$ direito penal é completo. ${ }^{27}$ No direito penal, todos os fatos são regulados.

${ }^{27}$ Carlos Alchourrón e Eugenio Bulygin afirmam que o princípio da legalidade é o exemplo mais conhecido de "regra de fechamento" (regla de clausura) $(2015, \mathrm{p}$. 198). 
Vinicius de Toledo Piza Peluso (2016, p. 176) fornece a seguinte explicação:

Assim, em matéria incriminadora e punitiva, pode-se afirmar que o sistema jurídico do Direito Penal é completo ou pleno, pois, em tal esfera, inexistem lacunas, a funcionar o princípio da legalidade, com seu corolário da proibição da analogia, como verdadeira norma geral excludente.

A teoria da norma geral exclusiva foi elaborada de forma a confrontar a existência das lacunas jurídicas. Segundo essa teoria, ao lado de toda norma jurídica é possível enxergar, por meio da interpretação, a existência de outra norma, geral e excludente. Essa norma geral excludente irá pegar todos os comportamentos não regulados pela norma (por isso é "geral") e conferir tratamento oposto àquele disposto por ela (por isso é "excludente"). Por exemplo: o artigo 128 do Código Penal estabelece que "não se pune o aborto praticado por médico: I - se não há outro meio de salvar a vida da gestante; II - se a gravidez resulta de estupro e o aborto é precedido de consentimento da gestante ou, quando incapaz, de seu representante legal". Dado nada dispor sobre outras situações de aborto ${ }^{28}$, seria possível afirmar que a hipótese de uma gestante querer abortar por não ter condições psicológicas de criar uma criança não foi prevista pelo legislador? Seria um exemplo de lacuna jurídica?

Segundo a teoria da norma geral exclusiva, não - porque, ao lado do artigo 128 do Código Penal, é possível enxergar uma norma geral excludente que relaciona todas as situações não previstas pela norma e confere o tratamento oposto; ou seja, todos os casos não previstos pela norma estão proibidos. ${ }^{29}$

\footnotetext{
${ }^{28}$ Além do aborto em caso de anencefalia, cuja legalidade foi reconhecida pelo Supremo Tribunal Federal no julgamento da ADPF 54.

${ }^{29}$ Norberto Bobbio sobre a teoria da norma exclusiva: "O raciocínio seguido por esses autores pode ser resumido assim: uma norma que regula um comportamento não só limita a regulamentação e, portanto, as consequências jurídicas que desta regulamentação derivam para aquele comportamento, mas ao mesmo tempo exclui daquela regulamentação todos os outros
} 
Por todos esses ângulos, percebe-se como o princípio da legalidade (e a consequente proibição da analogia) fornece um limite ao poder punitivo do Estado, evitando arbitrariedades. Não é coincidência, portanto, o fato da permissão da analogia na esfera penal ser permitida durante regimes totalitários, como visto durante a Segunda Guerra Mundial na Itália fascista e na Alemanha nazista. O caso da Alemanha nazista é ainda mais perverso, já que lá a analogia não era realizada com base em uma lei já existente, mas sim em relação ao que era chamada de "sentimento do povo". Ao juiz era permitido sancionar casos não regulados pela lei através de uma analogia ao sentimento do povo que tinha como objetivo buscar o espirito de Hitler nas leis (CAÑIZARES, 2019, p. 271-272). Após o fim da Segunda Guerra Mundial, com a derrota do nazismo, a analogia em matéria penal foi proibida.

Mas essa proibição da analogia não é absoluta, sendo permitida a chamada analogia in bonam partem (quando favorável ao réu). Essa relativização da proibição da analogia não é um aceno com a arbitrariedade; muito pelo contrário: ela é uma forma de concretizar os limites impostos ao poder punitivo do Estado. No direito brasileiro, é possível observar o raciocínio inerente a essa permissão ao ler o disposto pelo artigo $5^{\circ}, \mathrm{XL}$ da Constituição Federal, que, em um primeiro momento, proíbe a retroatividade da lei penal, mas, em um segundo momento, permite caso seja benéfica ao réu. Ou seja, a proibição da analogia é restrita à analogia in malam partem (quando prejudicial ao réu).

O princípio da legalidade penal, do qual emana o corolário da proibição de analogia, não abarca, segundo sua função de limitação e seu sentido garantístico, toda e qualquer matéria penal, mas apenas àquelas que traduzam a fundamentação ou agravação da responsabilidade penal do agente, pois, caso contrário, se também abrangesse as questões de exclusão e atenuação da responsabilidade, referido princípio passaria a funcionar contra a sua própria teleologia e sua própria ratio iuris, qual seja, a proteção dos direitos, liberdades e garantias dos cidadãos face à possibilidade permite, todos os outros comportamentos que não sejam fumar" (1995, p. 133). 
do arbítrio e do excesso do ius puniendi estatal (PELUSO, 2016, p. 175).

Pelo exposto, percebe-se a importância da distinção entre analogia e interpretação extensiva para o direito penal.

\section{2}

\section{Os mesmos traços distintos...}

Qual é o posicionamento da doutrina penal brasileira em relação à distinção entre analogia e interpretação extensiva? Unânime: são técnicas distintas e que não se confundem (BITTENCOURT, 2008, p. 154-156; SANTOS, 2014, p. 21-22; LIMA, 2017, p. 100-102; PACELLI, 2017, p. 71), sendo possível observar, inclusive, os mesmos sinais de alerta. ${ }^{30}$ Os traços de distinção apresentados são os mesmos já apresentados anteriormente: a analogia é técnica de integração do ordenamento jurídico, utilizada quando não há norma que regule o caso em questão, sendo a solução alcançada através da aplicação de outra norma que regule fato semelhante, culminando, portanto, na criação de uma nova norma; a interpretação extensiva, por outro lado, é um tipo de interpretação que amplia o alcance semântico de uma norma, inexistindo lacuna e não sendo necessária a criação de nova norma.

Seguindo as exigências do princípio da legalidade, a doutrina é unânime em afirmar que, em matéria penal, é permitido o uso da interpretação extensiva e da analogia in bonam partem, sendo proibida somente a analogia in malam partem.

\footnotetext{
30 "A analogia não se confunde com a interpretação extensiva ou mesmo com a interpretação analógica" (BITENCOURT, 2008, p. 155).
} 
Um exemplo da utilização da interpretação extensiva pode ser observado no artigo 235 do Código Penal ("contrair alguém, sendo casado, novo casamento"). Apesar de esse dispositivo tipificar expressamente o crime da bigamia, é possível estender essa proibição para outras situações, como a trigamia ou o poliamor. Essa extensão é justificada através da ratio legis, que não é a de proteger o casamento enquanto instituição, mas sim a de proteger a certeza das relações jurídicas, já que a formalização de um segundo casamento sem a término do primeiro pode causar inúmeras problemas de ordem contratual e sucessória, por exemplo. Sendo essa a ratio legis da lei, não há porque não estender a sua proibição para a trigamia ou o poliamor, já que em ambas as situações a certeza das relações jurídicas seria colocada em risco.

Já o artigo 181, I do Código Penal fornece um exemplo da aplicação da analogia in bonam partem. Ele dispõe que "é isento de pena quem comete qualquer dos crimes previstos neste título em prejuízo do cônjuge, na constância da sociedade conjugal". Seria possível ampliar a hipótese de incidência dessa isenção para a hipótese do crime cometido contra o companheiro? Segundo a analogia, sim. "Cônjuge" é aquele que está matrimonialmente vinculado à outra pessoa. Na união estável não há relação matrimonial, mas as duas situações possuem semelhanças que permitem a ampliação da isenção quando a vítima for o companheiro.

Por fim, um exemplo de analogia in malam partem, que é proibida em matéria penal: a cola eletrônica. Se o sujeito é pego com uma cola eletrônica, ele terá a sua prova recolhida, zerada e, caso seja candidato a alguma vaga ou concurso público, será excluído do processo seletivo; além disso, ainda sofrerá as reprovações morais e sociais decorrentes da prática desse ato. Colar é fraudar. Mas esse ato poderá ensejar a instauração de uma ação penal? Cola Eletrônica é crime? Não há, no Código Penal, qualquer norma que expressamente proíba essa prática. Logo, não seria possível dar início a uma ação penal em razão da ausência de tipicidade. Certa vez, o Ministério Público ajuizou ação penal 
contra um grupo de pessoas envolvidas em um esquema para fraudar um concurso público e que utilizavam, para tal fim, da cola eletrônica. Diante da ausência de previsão legal específica, o promotor utilizou o artigo 171 do Código Penal, que tipifica o crime de estelionato ("obter, para si ou para outrem, vantagem ilícita, em prejuízo alheio, induzindo ou mantendo alguém em erro, mediante artifício, ardil, ou qualquer outro meio fraudulento".) Segundo o promotor, apesar do artigo 171 do Código não tratar expressamente da cola eletrônica, há semelhanças observáveis, já que o uso da cola eletrônica é uma forma de obter vantagem indevida, induzindo alguém a erro. Entretanto, apesar das semelhanças, o Superior Tribunal de Justiça negou provimento ao recurso, sob o argumento de que a cola eletrônica, apesar de reprovável socialmente, é conduta atípica, não sendo possível utilizar da analogia em prejuízo do réu.

Tais exemplos permitem observar não somente como a doutrina se posiciona, mas também como os tribunais brasileiros estão compreendendo a distinção entre a analogia e interpretação extensiva.

Porém, além da interpretação extensiva, da analogia in bonam partem e da analogia em malam partem, a doutrina penal ainda apresenta um novo elemento: a chamada interpretação analógica.

Apesar do nome, ela não se confunde com a analogia. A interpretação analógica é um tipo de interpretação extensiva, pois ela também permite a ampliação das hipóteses de incidência contidas expressamente na norma para englobar situações semelhantes àquelas previstas. Ela é utilizada quando o próprio legislador faz referência à possibilidade da inclusão de situações semelhantes. Exemplos: artigos 71 ("Quando o agente, mediante mais de uma ação ou omissão, pratica dois ou mais crimes da mesma espécie e, pelas condições de tempo, lugar, maneira de execução e outras semelhantes, devem os subseqüentes ser havidos como continuação do primeiro, aplica-se-lhe a pena de um só dos crimes, se idênticas, ou a mais grave, se diversas, aumentada, em qualquer caso, de um sexto a dois terços") e $121, \S 2^{\circ}$, I do Código Penal ("Se o homicídio é cometido mediante paga ou promessa de recompensa, 
ou por outro motivo torpe") e o artigo 254 do Código de Processo Penal ("O juiz dar-se-á por suspeito, e, se não o fizer, poderá ser recusado por qualquer das partes se ele, seu cônjuge, ascendente ou descendente, estiver respondendo a processo por fato análogo"). Como é possível observar, em todos esses dispositivos o legislador deixou aberto, de forma intencional, a possibilidade abarcar outras situações não previstas textualmente pela norma. Foi, digamos assim, a própria lei que permitiu a possibilidade da interpretação análoga; e ela fez isso através dos termos "outras semelhantes", "por outro motivo torpe", "por fato análogo". Nessas situações, o intérprete terá que buscar semelhanças entre o fato tipificado e aquele em debate para justificar essa interpretação analógica.

Como a interpretação analógica é um tipo de interpretação extensiva, a sua utilização é permitida, seja ela favorável ou prejudicial ou réu.

A entrada de um novo elemento (uma interpretação por analogia que é um tipo de interpretação extensiva, mas que não se confunde com a analogia) acaba trazendo ainda mais desconfiança para a distinção entre analogia e interpretação extensiva, pois, apesar da unanimidade com a qual a questão é apresentada pela doutrina, há aqueles que, apesar de não discordarem da distinção, confessam inquietações.

Um deles é o professor Eugênio Pacelli, que, na obra Curso de Processo Penal, afirma que "as distinções entre interpretação analógica e analogia têm algo de arbitrário":

Assim, quando se fala em interpretação por analogia, já está se falando em interpretação analógica. E, com efeito, já se está utilizando a aplicação de uma norma prevista para regular a situação diversa, para resolver situação semelhante, não regulada. (...) Concluindo: quando a doutrina utiliza-se do conceito de interpretação analógica para ampliar o espaço normativo de uma mesma norma, ela está aplicando a interpretação extensiva. Interpretação analógica, rigorosamente falando, é o raciocínio por analogia, com a aplicação de nova norma (2017, p. 71-72). 
O trecho acima demonstra uma confusão comum entre a analogia e a interpretação extensiva, dando azo à afirmação de Engisch de que "a linha limítrofe entre a interpretação (especialmente a interpretação extensiva), por um lado, e a analogia, pelo outro, é fluida" (1996, p. 294). A interpretação analógica é uma forma de interpretação extensiva; mas, ao mesmo tempo, a distinção entre a interpretação analógica e a analogia tem algo de arbitrário, já que aplicar uma norma prevista para situação diversa para resolver situação semelhante não regulada (essa é a forma como Pacelli se refere à interpretação analógica) é exatamente o conceito de analogia.

Essa confusão também pode ser percebida nos exemplos utilizados. Voltemos à situação da cola eletrônica, já que essa situação voltou a ser debatida após o ano 2011, quando foi incluído um novo artigo no Código Penal: o artigo 311-A, que tipifica o crime de "Fraudes em certames de interesse público". Esse artigo dispõe que é crime "utilizar ou divulgar, indevidamente, com o fim de beneficiar a si ou a outrem, ou de comprometer a credibilidade do certame, conteúdo sigiloso de: I concurso público; II - avaliação ou exame público; III - processo seletivo para ingresso no ensino superior; ou IV - exame de processo seletivo previsto em lei”. A proibição da cola eletrônica está prevista neste dispositivo legal?

Expressamente, não. Para alguns doutrinadores, a lacuna em relação às colas eletrônicas ainda persiste. A favor desse argumento, têm-se o fato do artigo nada dispor sobre cola eletrônica; e ele ainda usa o termo "conteúdo sigiloso", que, é possível argumentar, só existe nos momentos que antecedem o início da prova: iniciada a prova, não há mais sigilo, o que retiraria a cola eletrônica da condição de aplicação prevista pela norma.

Entretanto, em 2017 o Superior Tribunal de Justiça considerou que a cola eletrônica viola o sigilo de prova de concurso público. Essa decisão ocorreu no recurso em habeas corpus n. $^{\circ}$ 81.735. Era um concurso público para o provimento do cargo técnico de assistente administrativo 
realizado pela Universidade do Pará no ano de 2015. O acusado foi o primeiro a terminar a prova e, ao sair, repassou o gabarito para outros candidatos por meio de um sistema de escuta. Em seu voto ${ }^{31}$, o relator Reynaldo Soares da Fonseca realizou uma interpretação extensiva do termo "conteúdo sigiloso":

A despeito da existência de divergência doutrinária sobre o tema, tenho para mim que o conteúdo sigiloso não deve se restringir, exclusivamente, ao gabarito oficial da Instituição organizadora do certame, mas, igualmente, abranger aquele especialista que realiza a prova e, antes de terminar o período de duração do certame, transmite, por meio eletrônico, as respostas corretas ou o seu próprio gabarito, ainda que sem correção doutrinária/legal, a outra candidatos que ainda encontram-se realizando o certame, pois, antes do término do prazo de duração da prova, as respostas de um candidato são sigilosas em relação aos demais candidatos que ainda encontram-se na realização do certame, sendo, pois, típico a denominada cola eletrônica desde que cometida após a entrada em vigor do artigo 311-A do Estatuto Penalista.

O que para uns é um uso indevido da analogia (porque prejudicial ao réu), para outro é uma forma legítima de ampliar o alcance das palavras contidas na norma através de uma interpretação extensiva.

Essas confusões entre as técnicas só demonstram o quanto a distinção entre a analogia e a interpretação extensiva demanda um maior cuidado.

${ }^{31}$ Disponível em: https://bit.ly/2Cfp1k8. Acesso em: 05 dez. 2020. 


\section{3 \\ ... e comuns}

Frente ao princípio da legalidade, a distinção entre a analogia e a interpretação extensiva ganha importância. E essa importância aumenta diante da crítica feira por Damiano Canale e Giovanni Tuzet (2014) e exposta no capítulo anterior; pois, se é possível alcançar o mesmo resultado através das duas técnicas, então qual é a razão de proibir uma e permitir a outra?

O caso da cola eletrônica e crime de fraudes em certames de interesse público (art. 311-A do Código Penal) ilustra essa crítica. É possível inserir a cola eletrônica dentro da tipificação penal tanto pela interpretação extensiva quanto pela analogia. $\mathrm{Na}$ primeira hipótese (adotada pelo STJ na decisão citada), o intérprete compreende o termo "conteúdo sigiloso" como sendo o gabarito oficial da prova, mas vislumbra a possibilidade de - seja por recurso à ratio legis, evolução social/jurídica ou pelo argumento da igualdade - ampliar seu significado pelo englobar também a cola eletrônica; afinal, tanto aquele que consegue acesso prévio e ilegal ao gabarito oficial quanto o candidato que repassa (ao sair da sala) as respostas para outro estão fraudando o certame. Na segunda hipótese, o intérprete compreende o termo "conteúdo sigiloso" como sendo tão somente o gabarito oficial da prova, não vislumbrando a possibilidade de ampliar esse significado para qualquer outro significado que não esse; para ele, o sentido das palavras é inequívoco. Porém, dada uma semelhança relevante entre o acesso e divulgação ilegal do gabarito e o candidato que faz da cola eletrônica, é possível - através da analogia - conferir ao caso não regulado (a cola eletrônica) a mesma consequência normativa prevista pelo art. 311-A do Código Penal. Nas duas hipóteses, duas justificativas diferentes, uma única resposta. Isso gera um problema teórico (há de se diferenciar a analogia da 
interpretação extensiva?) e um problema prático - pois, no direito penal, a primeira hipótese é permitida, enquanto a segunda não.

Os conceitos de analogia e interpretação extensiva são muito próximos e com linhas divisórias de difícil demarcação. Nas páginas anteriores foram utilizados inúmeros termos, todos muito parecidos, e é fácil se confundir perguntando se eles estão sendo utilizados como sinônimos ou não: analogia, interpretação extensiva, interpretação analógica, extensão analógica, aplicação analógica.

Quando Alf Ross (2000, p. 179) chama a interpretação extensiva de interpretação por analogia, por exemplo. ${ }^{32}$ Ele está equiparando intepretação extensiva e analogia ou está se referindo um tipo de interpretação extensiva? Ou quando Riccardo Guastini (2014, p. 112-113) apresenta dois sentidos para a interpretação extensiva - um estrito e um lato -, sendo que um desses sentidos se assemelha à analogia: no primeiro, a interpretação reduz a indeterminação da norma, estendendo o seu campo semântico para casos duvidosos; no segundo, a interpretação cria uma nova norma por meio de um argumento analógico que aponta as similaridades existentes entre os objetos em discussão. ${ }^{33}$

Confusão similar também é encontrada quando Jerzy Wróblewski (1992, p. 103) diferencia analogia extra legem e analogia intra legem: na primeira o fato não está regulado por norma legal, mas recebe o mesmo

32 Ou quando Alchourrón e Bulygin (2015, p. 199) afirmam que "a regra nulla poena requer como complemento a proibição da interpretação analógica da lei penal".

${ }^{33}$ Ao discorrer sobre os dois sentidos de interpretação extensiva, Riccardo Guastini utiliza o exemplo de uma norma que se aplica às "casas". Supondo-se uma concordância no sentido de que a palavra "casa" denota a residência em que se vive, ela certamente englobará o quarto e a cozinha e excluirá o local de trabalho; mas e o porão? Segundo Guastini, é possível, através de uma interpretação extensiva da norma, incluir tanto o porão quanto o local de trabalho: "Em um primeiro sentido (poderíamos dizer, estrito), constitui interpretação extensiva aquela que aplica a norma em questão também para o porão; (...) Em um segundo sentido (digamos, lato), constitui interpretação extensiva - ou, mais precisamente, aplicação analógica - aquela que aplica a norma também ao local de trabalho" (2014, p. 112). Como é possível observar, Guastini equipara a analogia à interpretação extensiva, colocando uma como espécie da outra. 
tratamento normativo conferido a fato semelhante; na segunda o campo semântico da norma, apesar de respeitado, é corrigido de forma a deixalo coerente com o ordenamento jurídico. Como se pode observar, o que ele refere como analogia extra legem é a analogia, enquanto a analogia intra legem é a interpretação extensiva; mas as duas técnicas são agrupadas sob um único termo.

Além disso, essa classificação feita por Wróblewski remete a um ponto de distinção recorrente entre a analogia e a interpretação extensiva, que é a diferença integração/interpretação. A analogia é uma técnica de integração, enquanto a interpretação extensiva é um tipo de interpretação. Esse traço distinto é constantemente citado; entretanto, ele não está isento de confusões. A diferença integração/interpretação pretende passar a ideia de que quando ocorre um inexiste o outro. Mas essa é uma ideia equivocada, porque sempre há interpretação na integração e viceversa. Eugênio Pacelli (2017, p. 70), por exemplo, afirma que a analogia e a interpretação extensiva estão situadas "no processo de autointegração das leis e do Direito, diante da necessidade de solução do caso concreto submetido à jurisdição". Sempre há integração - seja do ordenamento jurídico ou da norma jurídica - e, consequentemente, interpretação.

A diferença integração/interpretação pode ser um mecanismo utilizado para transmitir uma "neutralidade" para a interpretação extensiva, como se isso eliminasse a atividade criativa do intérprete. É dessa aparente "neutralidade" que deriva a legitimidade da interpretação extensiva, justificando a sua aplicação no direito penal em qualquer hipótese, seja ela benéfica ou prejudicial ao réu. Afinal, o intérprete só está ampliando as hipóteses de incidência da norma, respeitado suas possibilidades semânticas...

Damiano Canale e Giovanni Tuzet (2014, p. 227) apontam essa vulnerabilidade nos seguintes termos:

Uma das características distintivas da argumentação jurídica é a interação entre argumentos jurídicos que apoiam uma conclusão e diretrizes interpretativas que apoiam uma leitura específica das disposições legais que 
justificam a conclusão argumentada. Por um lado, uma interpretação definida dos materiais jurídicos relevantes visa fornecer as premissas normativas de um argumento jurídico a respeito de um caso ou de um conjunto de casos, mas, por outro lado, as próprias escolhas interpretativas precisam de justificativa e, portanto, ser apoiado por argumentos interpretativos (por exemplo, o argumento do significado literal das disposições relevantes, o argumento da intenção legislativa, o argumento do objetivo legislativo etc.).

Seja na analogia ou na interpretação extensiva, o intérprete sempre terá que justificar a sua escolha. O raciocínio que irá conferir ao caso não regulado o mesmo tratamento dispensado a caso regulado semelhante terá que ser justificado (as semelhanças existentes entre os casos são juridicamente relevantes?); da mesma forma como o raciocínio que expande a aplicação de uma norma para situações que não seriam contempladas por uma interpretação puramente literal (por que o significado das palavras utilizadas pelo legislador deve ser ampliado para englobar casos?).

Pelos motivos apresentados e pelas confusões expostas, é razoável afirmar que a distinção entre analogia e interpretação é fundada em pressupostos frágeis. Daí a impressão de que a distinção parece arbitrária. Alchourrón e Bulygin (2015, p. 199) fazem coro ao afirmar que a distinção "pode ser facilmente desvirtuada".

Como não ouvir o ruído?

Pelas questões apresentadas até aqui, percebe-se a fragilidade dos critérios utilizados para afirmar a distinção entre analogia e interpretação extensiva. E as semelhanças não podem ser ignoradas.

Qual o próximo passo? Aprofundar o conhecimento sobre essas duas técnicas. 
No próximo capítulo, investigaremos um tipo de argumento cuja aparição é recorrente nos estudos sobre a analogia: o argumento analógico. 


\section{Entre a indução e a dedução: a estrutura do argumento analógico}

A doutrina jurídica brasileira utiliza o termo analogia de forma bem específica: uma técnica de integração que atribui a um caso não regulamentado pelo direito a mesma disciplina conferida a um caso semelhante já regulamentado. Mas o significado utilizado pela filosofia é mais amplo. Paul Bartha (2013) resume nos seguintes termos: analogia é uma comparação entre dois objetos em que se destacam suas semelhanças; um raciocínio analógico é todo pensamento que se apoia nessa comparação; já um argumento analógico deve representar essa forma de raciocínio.

O objetivo do presente capítulo é investigar um tipo específico de argumento: o argumento analógico. A investigação partirá dos estudos da teoria da argumentação; por esse motivo, o sentido dado ao termo analogia será o mais amplo - uma comparação entre dois objetos, destacando-se as semelhanças. 
Pode-se utilizar vários adjetivos para a analogia - fundamental para o pensamento humano (Bartha, 2013); uma poderosa ferramenta cognitiva (Bermejo-Luque, 2014, p. 58); crucial para o discurso filosófico (Perelman, 1989, p. 409); central para o raciocínio jurídico (Schauer e Spellman, 2017, p. 101); o remédio para a falta de sucesso de qualquer interpretação (Canale e Tuzet, 2018, p. 80) -, menos um: simples.

André Juthe publicou nos últimos anos alguns artigos (2005; 2009; 2014) que tentam levar a cabo a seguinte proposta: realizar uma (exaustiva) revisão de toda a literatura já publicada sobre a analogia para tentar, assim, esboçar uma visão sistemática e classificatória sobre o tema. Uma proposta (alguns podem pensar) insana, dado o volume de livros, artigos e monografias já publicados sobre o assunto; mais insana, porém, é a conclusão preliminar a qual ele chegou: não há o menor acordo entre os autores. E o desacordo não se dá sobre questões superficiais, mas sim sobre o essencial. Alguns afirmam que a analogia nem é uma forma válida de raciocínio (ela tem, no máximo, algum valor retórico ou ilustrativo); outros afirmam que é uma forma válida de argumentação, mas redutível a uma forma de argumentação indutiva (mas há aqueles que acreditam que ela pode ser redutível a uma forma de argumentação dedutiva); outros acreditam que ela é sui generis, mas podendo ser classificada pelos mais diferentes parâmetros: status epistêmico, função, forma lógica, domínio, modo de inferência, objetos de comparação etc. (Juthe, 2014, p. 114).

Para alguns autores, o argumento analógico carece de força. Para Larry Alexander e Emily Sherwin, "semelhanças são infinitas; portanto, é necessária alguma regra ou princípio para identificar as semelhanças importantes" (2008, p. 76). Richard Posner: "Um conjunto de casos pode compor um padrão. Mas quando advogados e juízes diferem em qual padrão é composto, sua discordância não pode ser resolvida apelando a um senso intuitivo de padrão" (1990, p. 91). E Melvin Eisenberg: "A razão não pode ser usada para justificar uma conclusão normativa com base em um exemplo sem antes extrair dele uma máxima ou regra" (1988, p. 86). 
Seria o argumento analógico um tipo de argumento que carece de força? A resposta para essa pergunta pode ser encontrada através da análise da estrutura lógica de um argumento analógico, pois sua força pode ser aferida a partir da relação existente entre as premissas do argumento e a sua conclusão. ${ }^{34}$

Portanto, como descrever a estrutura do argumento analógico - em especial quando realizado no contexto jurídico?

Aqui o dissenso reaparece, já que, nas respostas a essas perguntas, há outro debate. Este capítulo abordará esse debate. Sua pretensão não é apresentar respostas definitivas para essas perguntas; talvez não existam respostas definitivas, sejam quais forem as perguntas. Seu objetivo é compreender esse tipo de argumento que é inerente à aplicação da analogia enquanto método de integração do ordenamento jurídico - e não há melhor forma de compreender um argumento do que analisando a sua estrutura. Assim que você divide um argumento em seus componentes, está apto a brincar com as engrenagens.

\section{1}

\section{Um começo}

No artigo "Classifying and Analyzing Analogies", Bruce N. Waller afirma que "quando disputas passam de ataques ad hominem para argumentos sérios, não há melhor meio de convencer os ouvintes e acalmar os debates do que o uso efetivo de analogias" (2001, p. 199).

Waller chama a atenção para um fato interessante referente à analogia: a sua efetividade em debates. Ele próprio cita alguns exemplos

34 "A lógica é o estudo da força da ligação entre as premissas e as conclusões dos argumentos" (Skyrms, 2000, p. 15). 
de debates filosóficos e de autores que, em seus artigos, fazem referência a uma analogia para provar/sustentar as suas conclusões (2001, p. 201). Vejamos alguns.

No artigo "Ill-gotten Gains" (1993), Tom Regan conta a história de uma repórter de um jornal norte-americano que, no ano de 1981, tendo como pauta a investigação do uso de lixo radioativo em solo nacional, acaba encontrando documentos oficiais que revelavam outra história, ainda mais impactante: uma enorme pesquisa, chefiada por um médico especialista em doenças cardíacas e financiada pelo Governo Federal, com o objetivo de descobrir medicamentos mais eficazes no tratamento da trombose coronária (ataque cardíaco); pesquisa essa que só mereceria os mais potentes aplausos - as doenças cardíacas estão entre aquelas que mais matam - se não fosse o seguinte problema: o método adotado. O médico responsável pelas pesquisas utilizava cobaias humanas em experimentos que envolviam a indução de ataques cardíacos. Cada pessoa recebia uma dose maciça de adrenalina, induzindo a trombose coronária, após a qual o médico começava a testar uma serie de medicamentos com o intuito de averiguar quais obtinham os melhores resultados. E ainda piora: a jornalista descobriu, através dos documentos oficiais já citados, que todas as cobaias humanas que se submeteram aos experimentos nunca tiveram qualquer história de doenças cardíacas. O médico não só induzia uma trombose coronária em seres humanos (um procedimento de enorme risco à saúde), como também o fazia em pessoas que nunca apresentaram qualquer sintoma de doença cardíaca.

Após quinze anos, a pesquisa foi dissolvida pelo Governo Federal - não por questões éticas, mas sim econômicas: uma crise econômica impediu a continuidade do repasse das verbas. Os resultados da pesquisa não foram divulgados para o público; na verdade, sequer a existência da pesquisa foi divulgada para o público - e ela continuaria em sigilo, se não fosse o trabalho investigativo da jornalista. 
Durante toda a narrativa do caso, Tom Regan se nega a dizer (sob o pretexto da proteção do anonimato) o nome do médico envolvido na pesquisa, o nome da jornalista, e até mesmo o nome do jornal. Ele inventa um nome para a jornalista (Karen) e para o médico (Doutor Ventricle). Em um primeiro momento, esse anonimato não chega a chamar a atenção, até que ele começa a não fazer mais sentido. Se essa é a história de uma reportagem investigativa, conduzida por uma jornalista e que - presume-se - foi publicada na imprensa, por que nem o nome do jornal pôde ser citado?

Nas palavras do próprio Tom Regan: "A história sobre Karen e o Dr. Ventricle é apenas isso - uma história, uma pequena peça de ficção. Não existe Dr. Ventricle, não existe Karen, e assim por diante" (1993, p. 195). Mas, por que o uso da fiç̧ão? Por que inventar uma história? Logo após confessar para o leitor que o caso que ele acabou de contar foi inventado, ele arremata: "Mas há um amplo uso de animais em pesquisas científicas, incluindo pesquisas como as do nosso imaginário Dr. Venticle. Assim, a história, apesar de seus detalhes serem imaginários - enquanto é, deixemos claro, um artifício literário, não um relato factual -, é uma história com um ponto" (1993, p. 195).

Tom Regan é, além de filósofo, um ativista pelos direitos dos animais. O ponto da história que ele inventou tem um objetivo claro: mostrar para o leitor que, apesar da história ser fictícia, a pesquisa e os experimentos que ela narra não o são - basta trocar "seres humanos" por "animais". A existência de pesquisas com animais é uma realidade conhecida por muitos, mas poucos se revoltam. A intenção de Tom Regan ao contar uma história fictícia sobre experimentos com seres humanos é sensibilizar o leitor. "A maioria das pessoas ficaria moralmente indignada se realmente houvesse um Dr. Venticle que fizesse pesquisa coronária do tipo descrito em seres humanos saudáveis" (1993, p. 196). Se o leitor ficar moralmente indignado com a história narrada, então - por analogia -, também deverá ficar em relação às pesquisas com animais. 
Essa comparação entre um caso fictício e uma situação real pesquisa coronária em seres humanos saudáveis e pesquisa coronária em animais saudáveis - é só o ponto de partida para que Tom Regan possa apresentar o seu argumento. Ele quer convencer o leitor. Ele quer demonstrar a imoralidade das pesquisas com animais.

No artigo "A Defense of Abortion" (1971), Judith Jarvis Thomson pede para o leitor se imaginar a seguinte situação. Você acorda e percebe que está em um hospital. No leito ao seu lado, há uma pessoa que você não conhece - e vocês estão conectados por uma sonda. Quando os médicos entram no quarto, eles explicam a sua situação. Na noite anterior, você foi drogado, sequestrado e trazido para o hospital por membros da Sociedade dos Amantes da Música. Por quê? Porque os membros dessa sociedade descobriram que você, e somente vocêê, possui o tipo sanguíneo compatível com o de um grande violinista que está sofrendo de um problema renal gravíssimo. A pessoa ao seu lado no quarto do hospital é esse violinista. Vocês estão conectados para que o seu rim faça o trabalho dobrado: ele está purificando o seu sangue e o do violinista. Os médicos também te informam que, dada a gravidade da situação do violinista, ele não pode sair da cama; como resultado disso, você não poderá sair do hospital, e terá que ficar conectado nele vinte e quatro horas por dia durante nove meses (os médicos estão construindo um equipamento capaz de purificar o sangue do violinista, mas só ele só ficará pronto depois desse período). Por fim, te informam que, caso você tente se desconectar do violinista, será algemado na cama pelos funcionários do hospital (que estão autorizados a usar da força, caso necessário).

Após contar essa história, Judith Jarvis Thomson pergunta ao leitor se essa obrigação - ficar algemado em uma cama de hospital purificando o sangue de um violinista que você viu/ouviu durante vinte e quatro horas em um período de nove meses - é moralmente legítima. Por um lado, ninguém nega que essa é uma situação extremamente inconveniente;

${ }^{35}$ Esse é um exemplo filosófico; recomenda-se a suspensão da descrença. 
mas, por outro, os médicos te garantem que a sua saúde não será afetada - e que a retirada da sonda que os conecta (você e o violinista) terá um único resultado: a morte do violinista. Em nenhum momento perguntaram a sua opinião; mas, agora, a vida do violinista está em suas mãos.

Judith Jarvis Thomson não afirma, como Tom Regan, que essa história fictícia tem um ponto. Mas isso nem é necessário, pois, como Tom Regan, ela também quer apresentar para o leitor um argumento; nesse caso, um argumento no debate do aborto. Thomson quer defender o aborto, especificamente no caso de gestações decorrentes de estupros. E qual é a serventia da história fictícia do violinista com problema renal? Mais uma vez, sensibilizar o leitor.

Quando o leitor se imagina naquela situação, das duas uma (basicamente): ou ele se compadece da situação do violinista e aceita se sujeitar a situação de ficar conectado a ele vinte e quatro horas por dia durante nove meses ("sei que não fiz nada para ser colocado nessa situação, mas não posso deixa-lo morrer"); ou ele se revolta contra a situação, arranca a sonda que os conecta, deixa o hospital e o mundo perde um grande violinista ("eu não fiz nada para ser posto nesse situação; sinto pelo violinista, mas não estou obrigado a salvar ou sustentar uma vida se eu não fiz nada para assumir essa obrigação - eu não criei a situação, não fiz uma promessa, não fiz nada de errado"). No primeiro caso, o leitor pode achar legítimo o uso da força por parte do hospital; no segundo caso, o leitor pode acha-la um absurdo.

É para esse segundo tipo de leitor que a analogia proposta por Thomson soará mais convincente, pois seu argumento é construído da seguinte maneira: se você acha um absurdo ser obrigado a salvar ou sustentar uma vida se não fez nada para merecer essa obrigação, então deverá ser a favor do aborto quando a gravidez resulta de estupro. Ser a favor de se desconectar do violinista e contra o aborto quando a gravidez resulta de estupro são dois posicionamentos incompatíveis. 
Nos dois exemplos acima, os autores querem contribuir com argumentos sérios para debates filosóficos complexos - pesquisas com animais, no primeiro, e aborto, no segundo -, e, em ambos, eles apresentam uma analogia para sustentar a conclusão que querem defender. $O$ interessante de ser notado é que os dois autores poderiam apresentar os seus argumentos sem a referência a analogia. Os dois poderiam defender as suas conclusões sem, necessariamente, fazer uso de situações hipotéticas: Tom Regan poderia defender a imoralidade das pesquisas com animais sem o auxílio da história da jornalista que desmarcara experimentos com seres humanos saudáveis; e Judith Jarvis Thomson poderia ter defendido o direito de a gestante abortar em caso de estupro sem fazer alusão a uma história inverossímil que envolve um violinista com grave insuficiência renal e sequestros conduzidos por membros da Sociedade dos Amantes da Música. Os dois autores poderiam eliminar essas situações hipotéticas dos seus artigos; mas não o fizeram. Por quê? A exclusão dessas situações hipotéticas enfraqueceria o argumento? Como explicar a afirmação de Waller, citada acima, de que "não há melhor meio de convencer os ouvintes e acalmar os debates do que o uso efetivo de analogias"?

O próprio Waller apresenta uma trilha para conduzir essa investigação:

\footnotetext{
"Infelizmente, muitas vezes há a suposição de que todas as analogias podem ser cobertas com uma única análise. O resultado é que (...) uma forma poderosa, mas complexa, de raciocínio, é simplificada. O primeiro passo para entender as analogias é reconhecer que elas vêm em diferentes variedades e executam funções distintas. Analisar um tipo de analogia pelos padrões de outro faz analogias legitimas parecerem fundamentalmente falhas" (2001, p. 199).
}

Sigamos a trilha junto com ele. 


\section{2}

\section{Argumentos dedutivos e indutivos}

Bruce N. Waller examina três tipos de analogias: figurativas, dedutivas e indutivas (2001, p. 199-203). ${ }^{36}$

Após afirmar que as analogias são, em geral, analisadas enquanto argumentos, ele chama a atenção para um tipo de analogia que não é utilizada para argumentar, mas sim para tão somente ilustrar ou elucidar (2001, p. 200). É a analogia figurativa, cuja função é a de chamar a atenção ou realçar alguma característica.

Um bom exemplo de analogia figurativa pode ser encontrado nas metáforas que os escritores de ficção utilizam. Como no romance "Anna Kariênina", quando a personagem Kitty diz que "os bracinhos do bebê são tão rechonchudos que parecem amarrados com linha" (Tolstói, 2005, p. 769); ou na descrição do abandono que Tchekhov faz ao visitar a cidade de Nikoláievsk: "Já hoje, quase metade das casas foi abandonada por seus donos, estão quase em ruínas e as janelas escuras e sem esquadrias olham para nós como as órbitas vazias de uma caveira" (2018, p. 15-16). Não é necessária nem mais uma única palavra para que o leitor consiga enxergar exatamente o tipo de casa que está sendo descrita.

Essa é a função de uma analogia figurativa - ilustrar ou elucidar. Tolstói ou Tchekhov não estavam argumentando; eles estavam descrevendo. Para auxiliar o leitor na visualização da cena, eles pegam dois objetos que, em um primeiro momento, não possuem qualquer relação, para, em seguida, iluminar uma característica em comum que

${ }^{36}$ Enquanto Waller apresenta três tipos de analogias, William R. Brown cita vários autores que descrevem somente duas: as analogias figurativas e as analogias literais (1989, p. 161). Waller também parte dessa distinção entre analogias figurativas e literais - mas, como se verá, sua visão quanto às analogias literais diferem daquilo que é usualmente apresentado na literatura sobre analogia. 
surpreende o leitor - que, por sua vez, se pega pensando "Olha, não é que é mesmo? O bebê é tão rechonchudo que seus braços parecem mesmo amarrados por corda”. É muito difícil formular uma boa analogia figurativa. Não é por acaso que alguns psicólogos, quando formulam testes de QI, constroem questões que trabalham com a capacidade de realizar - e, principalmente, visualizar -, analogias (Brown, 1989, p. 161). Um teste de QI criado pelo filósofo Ronald K. Hoeflin possui, entre as suas questões, uma seção intitulada "analogias verbais"; uma das perguntas é: "Dente está para a Galinha assim como Ninho está para?"37

É por esse motivo que a crítica literária costuma apontar, entre as qualidades de um bom escritor, um senso aguçado de observação (Wood, 2011, p. 63). Tem que ser um ótimo observador para olhar uma casa vazia e pensar que suas janelas são como os olhos de uma caveira. Quando o escritor acerta, quando a metáfora é boa, só resta ao leitor agradecer. Se uma imagem vale por mil palavras, uma boa metáfora vale por páginas e mais páginas de descrição.

Mas há analogias que são utilizadas com a finalidade de argumentar. Elas são utilizadas como razões em defesa de uma conclusão. Ocorre que os argumentos podem ser indutivos ou dedutivos. Um argumento analógico é indutivo ou dedutivo? Antes de respondermos a essa pergunta, precisamos apresentar a distinção entre indução e dedução.

Em primeiro lugar, é preciso observar que indução e dedução não são tipos diferentes de argumentação. A diferença entre indução e dedução não está na forma do argumento, mas sim na forma como o argumento é avaliado (Sinnot-Armstrong e Fogelin, 2010, p. 216).

Vejamos dois exemplos. ${ }^{38} \mathrm{O}$ primeiro representa um argumento dedutivo; o segundo, indutivo:

${ }^{37}$ Esse exemplo é citado por Malcolm Gladwell. "Você quer saber a resposta? Infelizmente nem desconfio" (2011, p. 89).

${ }^{38}$ Adaptado de Sinnot-Armstrong e Fogelin (2010, p. 215). 


\section{Exemplo 1 - argumento dedutivo}

1. Todos os corvos são pretos.

2. Se houver um corvo no topo da montanha, então ele é preto.

\section{Exemplo 2 - argumento indutivo}

1. Todos os corvos que observamos até agora são pretos.

2. Todos os corvos são pretos.

Em ambos os casos, uma estrutura de argumentação simples: uma premissa seguida de uma conclusão. Inicialmente é possível perceber que, no argumento dedutivo, a transição da premissa para a conclusão é realizada do geral para o particular, enquanto que, no argumento indutivo, a transição é realizada do particular para o geral. Mas essa não é a diferença definitiva entre eles. É verdade que a relação geral-particular e particular-geral pode ser encontrada, respectivamente, em vários argumentos dedutivos e indutivos; mas essa relação não é absoluta (Sinnot-Armstrong e Fogelin, 2010, p. 218). Como foi dito, a diferença definitiva entre eles está na forma como o argumento é avaliado - e essa diferença pode ser observada através da relação entre a premissa e a conclusão.

Conforme Fábio Shecaira e Noel Struchiner (2016, p. 23-24): "Argumentos indutivos procuram estabelecer a sua conclusão como sendo provável, dada a veracidade das premissas. Argumentos dedutivos pretendem estabelecer a sua conclusão como sendo necessária ou certa, dada a veracidade das premissas".

No exemplo de argumento dedutivo apresentado acima, a premissa estabelece um princípio universal (todos os corvos são pretos). Caso essa premissa seja verdadeira, então, necessariamente, um corvo específico será preto. Daí a conclusão do argumento (se houver um corvo no topo da montanha, então ele é preto). A conclusão tem a pretensão de ser necessária ou certa. 
Por outro lado, um argumento indutivo tem a pretensão de sustentar uma conclusão que é provável. Essa conclusão pode até se mostrar incorreta; mas a pretensão do argumento nunca foi estabelecer uma conclusão verdadeira. Vejamos o exemplo de argumento indutivo apresentado acima. A premissa não estabelece um princípio universal; ao contrário: nela, o autor tão somente está dizendo que todos os corvos que ele já viu foram da cor preta. E que, logo, é provável que todos os corvos sejam da cor preta. É possível que essa conclusão se mostre falsa? É claro que sim. Basta surgir um corvo que seja de uma cor distinta. A própria formulação da premissa deixa em aberto a possibilidade da existência de corvos de cores diferentes.

Em um argumento dedutivo, se a premissa é verdadeira, então a conclusão também é. Em um argumento indutivo, a premissa pode até ser verdadeira - mas isso não implica que a conclusão também será. A premissa "todos os corvos que observamos até agora são pretos" pode até ser verdadeira - mas isso não significa que, necessariamente, todos os corvos são pretos. Um argumento indutivo não tem a pretensão de estabelecer conclusões verdadeiras; sua pretensão é de estabelecer conclusões prováveis.

Por esses motivos, é possível afirmar que um argumento dedutivo não comporta gradações: ele é válido ou não é válido. Em um argumento indutivo, como a premissa quer fornecer uma razão que sustente a (provável) conclusão, ela pode ser avaliada como forte ou fraca (SinnotArmstrong e Fogelin, 2010, p. 217). Se o autor do argumento só conhece os corvos que observou no quinta da própria casa, o argumento perde muito a sua força; mas, se a pessoa viajou o muito inteiro com o objetivo de estudar os corvos e, dessa experiência, afirma que todos os corvos que já viu são pretos, seu argumento passa a ter muita força. E mesmo um argumento indutivo muito forte sempre está aberto à possibilidade de se sofrer um revés quando confrontado com uma nova premissa que poderá desqualificar a conclusão. Walter Sinnot-Armstrong e Robert Fogelin citam o exemplo da viagem do Capitão Cook para a Austrália 
(2010, p. 217). Até o momento da viagem, os europeus já haviam observado vários cisnes, e todos eles eram da cor branca - o que thes permitia enunciar um argumento indutivo: todos os cisnes que já observamos são da cor branca; logo, todos os cisnes são brancos. Um argumento, à época, forte. Até que o navio do Capitão Cook se aproximou da Austrália; lá, eles viram algo até então inédito: um cisne preto. O argumento perdeu toda a sua força.

Apresentada a distinção entre argumentos dedutivos e indutivos, voltemos à pergunta feita acima: um argumento analógico é dedutivo ou indutivo?

\section{3}

\section{A visão tradicional - e o desafiante}

Tradicionalmente, um argumento analógico é compreendido enquanto um argumento indutivo (Sinnot-Armstrong e Fogelin, 2010, p. 267).

É verdade que nem sempre é possível estabelecer se um determinado argumento é dedutivo ou indutivo; isso pode depender das intenções do autor do argumento. Como foi dito acima, dedução e indução não são diferentes tipos de argumento, mas sim diferentes formas pelas quais um argumento pode ser avaliado. Talvez a intenção do autor tenha sido a de garantir a veracidade da conclusão através da veracidade das premissas (nesse caso o argumento será dedutivo, como no seguinte exemplo: "Caetano Veloso é brasileiro; logo, ele necessariamente gosta de arroz e feijão"); ou talvez a intenção do autor tenha sido a de sustentar a probabilidade da conclusão através da veracidade das premissas (nesse caso o argumento será indutivo, como 
no seguinte exemplo: "Caetano Veloso é brasileiro; logo, ele provavelmente gosta de arroz e feijão") (Shecaira e Struchiner, 2016, p. 24-25). Dois exemplos de argumentos que só não são idênticos em razão de uma pequena diferença: o advérbio depois do "logo". Esse advérbio pode dar um indício da intenção ao autor do argumento.

E o autor de um argumento que faz menção a uma analogia possui, em geral, a intenção de tão somente sustentar a probabilidade da conclusão. Isso decore do fato de que a mera comparação entre dois objetos não consegue garantir, por si só, a veracidade da conclusão.

Walter Sinnot-Armstrong e Robert Fogelin (2010, p. 267-268) utilizam como exemplo a descoberta de uma faca em uma escavação. Após analisar as características da faca - tamanho, composição, forma -, os arqueólogos responsáveis pela descoberta afirmam que ela era utilizada em rituais de sacrifício; essa afirmação é embasada no fato de que a faca recém-descoberta possuí características muito semelhantes à de outras facas que foram comprovadamente utilizadas em rituais de sacrifício.

Nesse caso, qual foi a intenção dos arqueólogos com essa afirmação? Garantir com absoluta certeza que a faca recém-descoberta foi utilizada em rituais de sacrifício? Difícil sustentar isso; a simples comparação entre dois objetos não possui o condão de garantir uma afirmação categórica como essa. (Talvez se tivessem descoberto, junto à faca, o diário de um sacerdote que atestasse essa conclusão, e a veracidade do diário fosse comprovada... - mas não é o caso aqui.) 0 mais razoável é supor que a intenção dos arqueólogos foi de tão somente sugerir que a conclusão transmitida é provável, pois é perfeitamente possível que a faca recém-descoberta, apesar de todas as semelhanças com as outras facas que comprovadamente foram utilizadas em rituais de sacrifício, tenha sido, na verdade, um objeto comum no século passado, disponível em todas as casas. Talvez ela fosse somente um objeto de decoração, e nada mais. Talvez ainda descubram os dizeres "Made in China" gravados nela. Essas possibilidades sempre ficarão em aberto. 
Cass Sunstein, no artigo "On Analogical Reasoning", também afirma a natureza indutiva do argumento analógico (1993, p. 743). Ele cita o seu cachorro, um pastor alemão, que é muito carinhoso com as crianças - e diz que, quando vê outro pastor alemão na rua, parte do pressuposto de que ele também será carinhoso com as crianças. Cita também o seu carro, um Toyota Camry, e diz que o motor liga inclusive em dias de rigoroso inverso - e afirma que, por esse motivo, presume que o Toyota do vizinho também irá funcionar. É provável que essas pressuposições se mostrem corretas; mas não é possível garantir a sua veracidade. Talvez aquele pastor alemão em específico seja dotado de uma vontade inata e extrema por carnificina; talvez o Toyota do vizinho não funcione bem nem nos dias tranquilos de outono. Como o próprio Sunstein afirma, a analogia é uma forma de raciocínio comum na vida cotidiana, mas que não garante a verdade: "a existência de um ou mais características compartilhadas não significa que todas as características serão compartilhadas" (1993, p. 743-744).

Bruce N. Waller (2001, p. 202) apresenta a seguinte estrutura para representar um argumento indutivo analógico:

1. $D$ possui as características $e, f, g$ e $h$.

2. E também possui as características $e, f, g$ e $h$.

3. $D$ também possui a característica $k$.

4. Possuir as características $e, f, g$ e $h$ é relevante para possuir a característica $k$.

5. Logo, $E$ provavelmente irá possuir a característica $k$.

A natureza indutiva do argumento pode ser apreendida pelo advérvio "provavelmente" presente na conclusão. As premissas 1 e 2 apresentam as características compartilhadas dos dois objetos em comparação; a premissa 3 apresenta uma nova característica, observável (até o momento) em somente um dos objetos; a premissa 4 relaciona todas as características, as compartilhadas pelos dois objetos e a observável em somente um deles; e, por fim, a conclusão: dada a relação 
entre todos as características, é provável que a característica observável em somente um dos objetos também possa estar presente no outro.

Os filmes Zohan - Um Agente Bom de Cama (lançado no ano de 2008) e Lá Vêm os Pais (lançado em 2018) compartilham as seguintes características: são filmes de comédia, roteirizados por Robert Smigel e protagonizados por Adam Sandler. Uma característica observável no primeiro filme (mas não, ainda, no segundo) é a sua qualidade - ele é ruim. Todas essas características - gênero, roteiro, ator principal e qualidade - estão relacionadas, pois, em uma comédia, o texto e a atuação são importantes para determinar a sua qualidade. Logo, dada a relação entre as características, é possível afirmar (mesmo sem ter visto o filme em questão) que Lá Vêm os Pais também é, provavelmente, ruim.

1. Zohan - Um Agente Bom de Cama é um filme de comédia, roteirizado por Robert Smigel e protagonizado por Adam Sandler.

2. Lá Vêm os Pais também é um filme de comédia, roteirizado por Robert Smigel e protagonizado por Adam Sandler.

3. Zohan - Um Agente Bom de Cama é ruim.

4. Possuir as características gênero, roteiro e ator principal é relevante para estabelecer a característica qualidade.

5. Logo, Lá Vêm os Pais provavelmente irá possuir a mesma característica qualidade (ruim).

O exemplo que Waller (2001, p. 202) utiliza para explicar o argumento analógico indutivo envolve duas amigas: Alice e Bárbara. Elas são grandes amigas, e compartilham do mesmo gosto em várias áreas gostam da mesma culinária, dos mesmos carros, filmes, arquitetura e poesia. Diante desses gostos em comum, Alice pode concluir que a sua amiga também deve gostar de uma escritora que ela adora, a inglesa Penelope Fitzgerald. Afinal, o mesmo gosto em culinária, carros, filmes, arquitetura e poesia pode se estender também para a área da literatura histórica. 
Nos dois exemplos acima, argumentos que apontam conclusões que são prováveis: dada as premissas apresentadas, é possível que o filme Lá Vêm os Pais seja ruim e é possível que Bárbara adore a literatura de Penelope Fitzgerald. Mas as conclusões também podem ser mostrar equivocadas: mesmo em razão dos argumentos apresentados, também é possível que Lá Vêm os Pais seja um excelente filme e que Bárbara odeie Penelope Fitzgerald.

A estrutura fornecida por Waller (e os exemplos apresentados) descreve um argumento analógico indutivo como um argumento que irá comparar dois ou mais objetos e as suas características para concluir em razão da relação entre as características e da sua relevância para a conclusão - que uma característica observada em um objeto também será, provavelmente, observada no outro. Essa é a visão tradicional: compreender os argumentos analógicos enquanto argumentos indutivos.

Contra essa visão tradicional, Bruce N. Waller apresenta também o argumento analógico dedutivo. Ele é o desafiante. Em geral, a literatura aborda todos os argumentos analógicos como se fossem argumentos indutivos. Mas eles estão errados. Os argumentos analógicos também podem ser dedutivos - e, como tais, precisam ser avaliados sob um diferente padrão. "Analogias dedutivas não podem ser entendidas em termos de confiabilidade indutiva, já que não há um pingo de indução sobre elas" (Waller, 2001, p. 201).

Para explicar a estrutura de um argumento analógico dedutivo, Waller parte do já citado argumento a favor do aborto formulado por Judith Jarvis Thomson (2001, p. 200-201). Quando ela pede para o leitor imaginar a situação de uma pessoa que foi sequestrada e conectada a um violinista com grave problema renal, pode parecer, em um primeiro momento, que ela está fazendo uso de uma analogia figurativa. Pode parecer que a menção à analogia cumpre a simples função de iluminar ou elucidar alguma característica. Mas não - Judith Jarvis Thomson quer apresentar um argumento: o de que as mulheres possuem o direito ao aborto caso a gravidez seja decorrente de estupro. E esse é um 
argumento dedutivo. Ao realizar a analogia do violinista com grave problema renal, Thomson quer levar o leitor a pensar sobre as razões que balizaram a sua (do leitor) decisão. É correto o hospital usar a força para manter uma pessoa conectada ao violinista vinte e quatro horas por dia durante nove meses? Caso o leitor acredite que não, ele, ao dizer o porque, pode formular um princípio universal: "não posso ser obrigado a salvar ou sustentar uma vida caso não tenha feito nada para assumir essa obrigação".

O leitor não está dizendo que, em geral, as pessoas acreditam que não possuem a obrigação de salvar ou sustentar uma vida caso não tenham feito nada para assumir essa obrigação. Ele está, ao contrário, estabelecendo um princípio universal. E, por ser um princípio universal, a consistência pede que ele seja aplicado em todos os casos que são semelhantes. Se, portanto, o caso da gestante cuja gravidez decorre de estupro é considerado como semelhante ao caso do violinista com insuficiência renal, então a consistência requer que o mesmo princípio seja também aplicado. Da mesma forma que a pessoa tem o direito de se desconectar do violinista, a gestante também possui o direito de abortar. Defender um e não o outro é uma inconsistência. Concordando com o princípio universal formulado e concordando com a analogia estabelecida, a conclusão é necessária. Não há indução; o que há é uma dedução de um princípio.

Bruce N. Waller (2001, p. 201) apresenta a seguinte estrutura para representar um argumento analógico dedutivo:

1. Nós concordamos com o caso a.

2. A razão mais plausível para acreditar em a é a aceitação do princípio $C$.

3. $C$ implica em $b$ ( $b$ é um caso que se enquadra no princípio $C)$.

4. Portanto, a consistência requer a aceitação de $b$.

Transportando o argumento de Judith Jarvis Thomson para essa estrutura, temos: 
1. Nós concordamos que uma pessoa não pode ser forçada a salvar a vida do violinista.

2. A razão mais plausível para acreditar nisso é a aceitação do princípio segundo o qual não é possível obrigar alguém a salvar ou sustentar uma vida caso não tenha feito nada para assumir essa obrigação.

3. Esse princípio implica em permitir o aborto em caso de gravidez decorrente de estupro.

4. Portanto, a consistência requer a aceitação do aborto em caso de gravidez decorrente de estupro.

Ao contrário de um argumento indutivo, que pode ser forte ou fraco, um argumento dedutivo ou é válido ou é inválido. Diante de um argumento analógico dedutivo, há duas formas de contestá-lo. Primeiro, contestando o próprio princípio universal formulado ("na verdade, eu não concordo com isso; na minha opinião, nós sempre temos a obrigação de salvar ou sustentar uma vida, independente das circunstâncias"). Segundo, contestando a própria analogia ("eu até concordo que não é possível obrigar alguém a salvar ou sustentar uma vida caso não tenha feito nada para assumir essa obrigação, mas o caso da gestante é completamente diferente do caso do violinista; há uma relação biológica no primeiro caso que não existe no segundo: a mãe está sustentando a vida do seu próprio filho, enquanto, no segundo caso, a pessoa sequestrada está sustentando a vida de uma pessoa que nunca viu ou ouviu na vida").

\section{4}

O contra-ataque da visão tradicional - e a defesa dos argumentos analógicos dedutivos

A possibilidade proposta por Waller - de compreender os argumentos analógicos enquanto argumentos dedutivos - acabou por 
gerar um enorme debate. Mandred Kraus (2015, p. 171) apresenta o panorama desse debate:

\begin{abstract}
Argumentos por analogia tem sido, recentemente, um assunto muito disputado. As questões mais controversas nessa discussão têm sido sobre a existência ou não de diferentes tipos de argumentos analógicos, se eles devem ser considerados basicamente como dedutivos ou indutivos ou como uma categoria completamente distinta de argumentos, se há ou não alguma premissa oculta ou ausente, e se é possível que os argumentos analógicos sejam dedutivos e ainda assim inderrotáveis.
\end{abstract}

A proposta de Waller foi criticada por Trudy Govier (2002) e Marcello Guarini (2004). A estrutura do argumento analógico dedutivo é compreendida por Waller como contendo um princípio universal; a conclusão será dada pela semelhança entre os casos, deduzida desse princípio. A crítica é direcionada a esse princípio universal, pois, na prática, ele raramente é explicitado pelo autor do argumento. Na maioria dos casos, ele fica implícito no argumento, tornando praticamente impossível o trabalho de determina-lo. $\mathrm{Na}$ analogia do violinista com insuficiência renal, o princípio universal presente no argumento dispõe que "não é permitido obrigar alguém a salvar ou sustentar uma vida caso ela não tenha feito nada para assumir essa obrigação". Mas, e se esse princípio não tivesse sido explicitado? O autor do argumento poderia tão somente ter comparado o caso do violinista com o da gravidez decorrente de estupro sem mencionar qualquer princípio universal. É verdade que poderíamos refletir sobre o argumento e acabar pressupondo o princípio mas, como garantir que o princípio que pressupomos foi exatamente o princípio que o autor do argumento tinha em mente? Como garantir que ele não tinha outro princípio em mente, como, por exemplo, "a liberdade humana é absoluta; qualquer pessoa pode fazer o que quiser"? Ou, pior: como garantir que o autor do argumento tinha algum princípio universal em mente? Segundo Trudy Govier, se precisamos pensar (criticamente, filosoficamente) para descobrir o princípio universal implícito, então ele não pode ser considerado um elemento do argumento analógico (2002, p. 155-156). E, se ele não faz parte do argumento analógico, então a estrutura proposta por Waller é falha. 
Em defesa da visão dedutivista proposta por Waller, Fábio Perin Shecaira publicou o artigo "Analogical Arguments in Ethics and Law: A Defense of a Deductivist Analysis" (2013), aonde afirma que as críticas feitas por Govier e Guarini decorrem de uma "leitura implausível" do texto de Waller.

Waller é o primeiro a admitir que, em alguns casos, é difícil formular o princípio universal que governa um argumento analógico dedutivo (Waller, 2001, p. 205). Mas, mesmo diante dessa dificuldade, ele continua afirmando a sua importância na estrutura do argumento.

Se deixarmos o princípio universal de lado, então o argumento será avaliado somente a partir das semelhanças e diferenças apontadas. E, quando estamos diante de casos complexos (como o direito ao aborto, por exemplo), não é possível fazer isso. Excluindo o princípio universal do argumento, o caso do violinista seria retratado da seguinte maneira: "O caso do violinista é semelhante à uma gravidez decorrente de estupro; eu acho que a pessoa sequestrada tem o direito de se desconectar do violinista; logo, também defendo o direito ao aborto quando a gravidez decorrer de estupro". Mas essa linha de argumentação seria facilmente rebatida caso um interlocutor dissesse que os casos não são semelhantes e que, por esse motivo, a analogia é descabida. Para solucionar esse embate, teremos que começar a questionar o porquê da semelhança. Teremos que encontrar o princípio universal; caso contrário, o embate não irá prosseguir. "Sem um exame explícito do porquê acreditamos que temos o direito de se desconectar do violinista, a disputa provavelmente se esvairá em 'intuições' conflitivas que são afirmadas com veemência crescente" (Waller, 2001, p. 205).

Essa defesa do dedutivismo acaba por afirmar a própria importância da analogia para o pensando crítico: "a analogia nos obriga a realmente pensar sobre os princípios que mantemos e sobre as suas implicações futuras" (Waller, 2008, p. 208). 
Para demonstrar a importância da descoberta do princípio universal, Waller (2001, p. 207) pede ao leitor para imaginar um professor que usa a analogia do violinista em sala de aula, durante um debate sobre aborto, mas sem explicitar o princípio - ele tão somente diz que os casos são semelhantes e que, portanto, devem ser decididos da mesma forma. Alguns alunos podem reconhecer a força da analogia de imediato; eles enxergam a semelhança e concordam com ela. Outros podem discordar da analogia ou não a entender, e começarão a questionar: "por que você acha que possui o direito de se desconectar do violinista?" Mas, a partir do momento em que eles descobrem o princípio que serve como razão para a conclusão, eles podem perceber que o mesmo princípio também se encaixa no caso da gravidez decorrente de estupro - e aí a analogia começa a fazer sentido. Ou talvez não; talvez eles discordem do princípio, por acreditarem (por exemplo) que toda vida deve ser salva ou sustentada, independente da circunstância. Não importa, pois, mesmo que isso ocorra, pelo menos os alunos irão entender as razões do professor e o porquê dele enxergar as semelhanças entre os casos levando o debate para outro nível, que não se esvairá em intuições conflitivas afirmadas com veemência crescente.

A analogia nos ajuda a reconhecer um princípio que nós já adotamos - mas que talvez ainda não tenhamos explicitado (Waller, 2001, p. 208). O princípio não é fixo ou absoluto39; sua descoberta envolve um processo dinâmico, que compreende a análise do argumento utilizado em um caso concreto e as implicações em casos futuros. Um caso futuro pode reformular o princípio que foi previamente identificado. É o que Waller irá chamar de "processo de ajuste mútuo" - entre o princípio e o caso concreto.

Para exemplificar, Waller cita (2001, p. 208-209) um argumento analógico desenvolvido por John Martin Fischer. Esse argumento visa desafiar a analogia do violinista proposta por Judith Jarvis Thomson. Ele

39 "O princípio não está consagrado entre as formas platônicas, não é uma 'onipresença no céu', e nem sempre é logicamente ou epistemicamente prévio" (Waller, 2001, p. 208). 
também pede para o leitor se imaginar em uma situação. Aqui vai ela, com pequenas adaptações.

Imagine que você está planejando longas férias - nove meses de férias, para sermos exatos. Após vários anos de trabalho ininterrupto, suportando todo tipo de pressão física, moral e espiritual inerente ao mundo contemporâneo que parece só querer sugar todas as suas forças como um vampiro, tudo o que você quer é solidão. Nove meses de total isolamento. Você contrata uma viagem com uma agência de turismo: uma cabana localizada no alto de uma montanha, acessível somente por helicóptero e distante de qualquer sinal de civilização. Não há rua ou caminho que permita o acesso/a saída da montanha, telefone, internet ou torre de celular próxima. Completo isolamento. Quando chega o dia agendado para a viagem, o helicóptero te leva até a cabana e promete voltar daqui a nove meses para te buscar. Ao entrar na cabana e trancar a porta às suas costas, você reserva alguns segundos para prestar atenção no silêncio. Finalmente, paz e tranquilidade.

Mas o sossego é rapidamente interrompido por um estrondo atrás de você; tem uma pessoa batendo desesperadamente na porta; depois de perguntar quem é, a pessoa diz que foi sequestrada, roubada e abandonada nessa montanha, sem ter o que comer e beber, mas que felizmente ouviu o barulho do helicóptero e, ao se aproximar, viu uma pessoa (você) entrando nessa bela e aconchegante cabana, uma tremenda sorte porque a temperatura está caindo a cada dia, sinalizando um rigoroso inverno que se aproxima.

O que você faz? Abre a porta e vocês dividem a cabana pelos próximos nove meses? Ou deixa a pessoa perecer no inverno da montanha? (A história que a pessoa te contou é verdadeira; ela não é um serial killer. $E$ há mantimentos suficientes na cabana para vocês dois passarem os próximos nove meses sem que seja necessário preocupar com comida.) 
Da mesma forma como na história do violinista, essa não tem a intenção de ser ilustrativa ou elucidativa. Ela quer provar um ponto. Ela quer provar a nossa inconsistência moral.

Suponha que uma pessoa afirme, no caso do violinista, o princípio segundo o qual "ninguém pode ser obrigado a salvar ou sustentar uma vida caso não tenha feito nada para assumir essa obrigação". Nesse sentido, em nome da consistência, essa mesma pessoa não abrirá a porta da cabana?

Por mais que alguém sonhe com nove meses de férias em total isolamento, é razoável supor que qualquer pessoa achará moralmente errado não abrir a porta da cabana. Isso significa que aquele que reconhecer o direito do sequestrado de se desconectar do violinista (e da gestante em abortar) e que decide por abrir a porta da cabana está sendo inconsistente com os princípios que adora?

Não necessariamente, responde Waller. A intenção da analogia proposta por John Martin Fischer é mostrar a nossa inconsistência moral; ele almeja conseguir isso nos fazendo perceber que o princípio que adotamos no caso do violinista (ninguém pode ser obrigado a salvar ou sustentar uma vida caso não tenha feito nada para assumir a obrigação) fornece uma resposta diferente daquela que damos para o caso da cabana. Como Waller afirma, os princípios não são previamente determinados; cada pessoa possui os seus valores morais, mas eles não foram (ainda) plenamente explicitados. Isso só irá ocorrer através da análise de casos concretos - e, mesmo nesses casos, o princípio que é formulado ainda aparece em estágio embrionário, pois ele pode ser aperfeiçoado quando confrontado com outros casos. Esse é o "ajuste mútuo" entre princípio e caso concreto que Waller faz menção (2001, p. 208).

Decidir pelo direito de se desconectar do violinista e abrir a porta da cabana não são decisões inconsistentes. O caso da cabana (e a decisão de abrir a porta) terá, na verdade, a consequência de reavaliar o 
princípio anteriormente explicitado, que agora pode ser formulado dessa maneira: "ninguém pode ser obrigado a usar o próprio corpo para sustentar ou salvar uma vida caso não tenha feito nada para voluntariamente assumir essa obrigação". Essa reformulação comporta as duas decisões - a de se desconectar do violinista e a de abrir a porta da cabana. Isso não é inconsistência, mas um processo dinâmico no qual os princípios vão sendo revistos (e melhorados) à luz de novos casos.

Como foi dito acima, o debate sobre a estrutura do argumento analógico - se indutivo ou dedutivo - é complexo. Ele está longe de alcançar um fim. Mas as considerações de Waller permitem afirmar, ao menos, a possibilidade de um argumento analógico ser compreendido como indutivo ou dedutivo (nesse caso, mesmo nas situações em que o princípio universal não é explicitamente formulado).

Diante desse cenário, é possível voltarmos ao questionamento realizado no início desse capítulo: Como descrever a estrutura do argumento analógico quando utilizado para integrar o ordenamento jurídico? Ele é mais bem descrito como um argumento indutivo ou dedutivo?

\section{5}

\section{De volta ao universo jurídico}

Fábio Shecaira e Noel Struchiner (2016, p. 113-115) apresentam duas estruturas de argumento:

\section{Estrutura 1}

1. Uma situação $S 1$ é juridicamente regulada da maneira $M$. 
2. $S 1$ é semelhante a outra situação $S 2$ no que diz respeito às características juridicamente relevantes $C 1$, C2, ... Cn.

3. Logo, S2 deve ser juridicamente regulada da mesma maneira $M$.

\section{Estrutura 2}

1. Uma situação $S 1$ é juridicamente regulada da maneira M.

2. $S 1$ é semelhante a outra situação $S 2$ no que diz respeito às características juridicamente relevantes $C 1$, C2, ... Cn.

3. Toda situação que apresente as características $C 1$, $C 2, \ldots$ Cn deve ser regulada da mesma maneira $M$.

4. Logo, S2 deve ser juridicamente regulada da mesma maneira $M$.

A Estrutura 1 representa um argumento analógico indutivo; a

Estrutura 2, um argumento analógico dedutivo. Qual é a diferença entre eles? A forma de avaliação do argumento.

Conforme visto no decorrer deste capítulo, um argumento indutivo não tem a pretensão de apresentar a conclusão como necessária ou certa. A veracidade das suas premissas não garante a veracidade da conclusão. Não é porque um Fiat Uno e uma Ferrari 250 GTO possuem a mesma cor vermelha (Premissa) que eles terão o mesmo valor de mercado (Conclusão). A Premissa até pode ser verdadeira, mas a sua veracidade não significa necessariamente a veracidade da conclusão. $O$ dono de um Fiat Uno pode até argumentar que o seu carro deve possuir o mesmo valor de mercado de uma Ferrari 250 GTO, dada uma semelhança em comum. Mas esse argumento seria rapidamente rechaçado, e por um motivo simples: a semelhança que ele utiliza como suporte para a conclusão não tem força; ela não é relevante para a conclusão que se pretende afirmar. Um argumento indutivo pode ser fraco ou forte, a depender da força das premissas. E ele poderá ser criticado por dois motivos: ou porque não se concorda com a semelhança apontada, ou porque não se concorda que a semelhança apontada seja relevante para a conclusão defendida. 
As características apontadas no parágrafo acima estão presentes na Estrutura 1, que é exemplificada por Shecaira e Struchiner (2016, p. 114) da seguinte maneira:

1. Quem dirige embriagado [situação original] deve ser punido [tratamento já dispensado por alguma fonte do direito, como a lei].

2. Dirigir embriagado [situação original] é semelhante a dirigir sob a influência de maconha [situação debatida], visto que as duas substâncias prejudicam a atenção e os reflexos do motorista [semelhanças juridicamente relevantes entre as duas situações].

3. Logo, quem dirige sob a influência de maconha também deve ser punido.

A primeira premissa afirma como uma determinada situação é regulada pelo direito. Não há controvérsia quanto a isso; esse é um pressuposto do argumento analógico enquanto método de integração de lacunas, pois, se há alguma controvérsia quanto à regulação dispensada pelo direito para determinada situação, são poucas as chances do argumento convencer o interlocutor. ${ }^{40}$

A segunda premissa, por outro lado, pode gerar controvérsia. Ela "costuma ser o principal alvo daqueles que não se sentem convencidos por um argumento analógico" (Shecaira e Struchiner, 2016, p. 113). E o motivo disso se dá porque é nela que as semelhanças entre os dois objetos serão apontadas. Se os objetos são semelhantes ou não, ou se as semelhanças são relevantes ou não para a conclusão - isso pode gerar debate. Quando o autor do argumento diz que dirigir embriagado é semelhante a dirigir sob a influência de maconha porque ambas prejudicam a atenção e os reflexos do motorista, o interlocutor pode até concordar - mas isso não significa, necessariamente, que ele irá endossar a conclusão de que dirigir sob a influência de maconha também

40 "O autor do argumento analógico confia que não haverá controvérsia a respeito disso. Afinal, o objetivo do argumento é mostrar que a maneira consensual de regular a situação original deve ser estendida a uma nova situação, ora sob debate (a "situação debatida"). A primeira premissa não é aquela que tende a gerar mais controvérsia, pois, se a regulação da situação original também for controvertida, a analogia terá pouca chance de prosperar no que diz respeito à situação debatida" (Shecaira e Struchiner, 2016, p. 113). 
deve ser punido. Disso ele pode discordar. Ele pode acreditar, por exemplo, que o consumo de maconha não chega a ser tão prejudicial para a atenção e os reflexos do motorista quanto o consumo de bebidas alcoólicas. Talvez, para ele, a maconha seja tão prejudicial quanto um remédio antidepressivo - e a lei não proíbe o motorista de dirigir sob o efeito desses medicamentos. Ou seja, ele até concorda que a maconha, assim como o álcool, pode prejudicar a atenção e os reflexos do motorista, mas isso não significa que o motorista que estiver sob o seu efeito deva ser punido. A veracidade das premissas não importa necessariamente na veracidade da conclusão. É provável que aquele que concorde com as semelhanças também concorde com a conclusão; da mesma forma que é provável que aquele que concorde com as semelhanças discorde da conclusão.

O autor do argumento irá, provavelmente, discordar do seu interlocutor. Mas ele poderá acusá-lo de inconsistência? Não.

Imaginemos que o autor do argumento se dirija ao interlocutor acusando de inconsistência. "Você não pode concordar que a maconha é prejudicial à atenção e aos reflexos do motorista e, ao mesmo tempo, discordar que quem dirige sob o efeito da maconha seja punido", diz. Ao que o interlocutor rebate: "Sim, eu concordo com você que a maconha é prejudicial à atenção e aos reflexos do motorista; mas em nenhum momento eu disse que quem dirige sob o efeito de qualquer substância que prejudique a atenção e os reflexos deve ser punido".

O mesmo não poderia ser dito caso o argumento fosse dedutivo. Esse é o exemplo que Shecaira e Struchiner (2016, p. 115-116) utilizam na representação do argumento analógico dedutivo (Esquema 2):

1. Quem dirige embriagado deve ser punido.

2. Dirigir embriagado é semelhante a dirigir sob a influência de maconha, visto que as duas substâncias prejudicam a atenção e os reflexos do motorista.

3. Quem dirige sob a influência de qualquer substância que prejudique a atenção e os reflexos do motorista deve ser punido. 
4. Logo, quem dirige sob a influência de maconha também deve ser punido.

Diferente do argumento indutivo, a estrutura de um argumento analógico dedutivo possui uma premissa adicional. Essa premissa adicional (Premissa 3 no Esquema 2) apresenta um princípio universal. Quem dirige sob a influência de qualquer substância que prejudique a atenção e os reflexos do motorista deve ser punido. Aqui, não se pretende afirmar que a conclusão é provável. Ao contrário: dada a veracidade das premissas, a conclusão é certa ou necessária. A veracidade das premissas implica na veracidade da conclusão. Se uma pessoa acredita que (i) dirigir sob a influência de maconha prejudica a atenção e os reflexos do motorista e que (ii) quem dirigir sob a influência de qualquer substância que prejudique a atenção e os reflexos do motorista deve ser punido, então, necessariamente, ela terá que concordar que quem dirige sob a influência de maconha deve ser punido. Caso contrário, ela poderá ser acusada de inconsistência.

Diante desses dois esquemas, qual é aquele que melhor descreve o argumento analógico utilizado pelos juristas?

Para Shecaira e Struchiner, o argumento analógico é melhor descrito enquanto argumento indutivo. "Preferimos, aqui, o esquema 1 ao esquema 2. Os autores de argumentos analógicos nem sempre formulam princípios explicitamente; quando muito, eles explicam em que são semelhantes as duas situações, a original e a debatida" (2016, p. 117).

Os autores de argumentos analógicos, quando muito, explicam as semelhanças entre as situações. Essa afirmação é interessante; ela ilumina a principal crítica direcionada ao argumento analógico. É fácil encontrar pontos comuns em situações que são distintas; e, a partir do momento em que a argumento analógico não explicita os seus princípios, a sua força se esvai.

O raciocínio analógico é todo pensamento que se apoia na comparação entre objetos; e ele é muito comum. O utilizamos inúmeras 
vezes no dia a dia - quando dizemos que um carro deve ser bom (porque ele é da mesma montadora que só produziu bons carros), quando dizemos que um filme que acaba de chegar aos cinemas deve ser ruim (porque $\mathrm{o}$ ator principal é conhecido por só protagonizar filmes desastrosos), quando dizemos que um prato da culinária mexicana deve ser apimentado (porque toda a culinária mexicana que já experimentamos estava picante)... Um argumento analógico, por sua vez, deve representar essa forma de raciocínio. Sua fraqueza: é fácil encontrar semelhanças entre duas situações; sempre há características em comum. Por esse motivo, toda análise de semelhança parece ter algo de arbitrário, pois, como é possível inferir de forma intuitiva, é possível encontrar semelhanças mesmo entre os objetos mais díspares. Uma pessoa pode olhar para uma Ferrari 250 GTO e dizer que é igual ao carro que possui (um Fiat Uno vermelho).

Ao resenhar uma monografia sobre analogia, o professor Kenny Easwaran afirmou que esse é "um tópico muito difícil de escrever". Segundo ele, "a fraqueza dos argumentos e a diversidade de domínios em que são aplicados tornam difícil o próprio fenômeno de classificação" (2011). O debate sobre a descrição do argumento analógico (se indutivo ou dedutivo) é uma prova disso. Esse debate ainda está longe de uma conclusão. Conforme dito no início deste capítulo, pode-se utilizar vários adjetivos para a analogia, menos um: simples. Mas o conhecimento desse debate é importante porque, a partir do momento em que se divide um argumento em seus componentes, estamos aptos a brincar com as engrenagens. E uma dessas engrenagens é o raciocínio analógico. 


\section{Ruído de fundo: a contribuição das ciências cognitivas para a compreensão do raciocínio analógico}

Como explicar o processo cognitivo responsável pelo raciocínio analógico? Ou, em outras palavras: como raciocinamos analogicamente?

Os cientistas cognitivos que se dedicaram ao tema da analogia costumam utilizar as seguintes terminologias: o caso anterior é chamado de fonte ("source"); o caso atual é chamado de alvo ("target"). O raciocínio analógico, entendido como todo pensamento que se apoia na comparação entre objetos, ocorre quando compreendemos que uma característica do objeto fonte está presente no objeto alvo (HOLYOAK e THAGARD, 1994; HOLYAK, 2005, p. 117; SCHAUER, 2009, p. 87).

Mas, dada a facilidade existente em se encontrar semelhanças entre objetos, existe uma falta de confiabilidade nessa forma de raciocínio - falta de confiabilidade essa que irá reverberar para as suas mais variadas utilizações, como os argumentos analógicos. No diálogo "O Sofista", Platão aconselha cautela: "Como o lobo se parece com o cão, o animal mais selvagem com o mais manso. Quem é precavido emprega com cautela semelhantes comparações; é um gênero escorregadio" (1980, p. 72). Em "O Leviatã", Thomas Hobbes afirma que raciocinar por meio de comparações "é o mesmo que perambular entre inúmeros 
absurdos, e seu fim é a disputa, a sedição ou a desobediência" (2019, p. 59). ${ }^{41}$

Essa falta de confiabilidade é justificada? Nas últimas décadas, vários experimentos foram realizados por psicólogos e cientistas cognitivos com o intuito de compreender essa forma de raciocínio - e, a julgar pelos resultados encontrados, é possível sim justificar essa falta de confiabilidade. Podemos, inclusive, afirmar que o raciocínio analógico chega a ser irracional. Michael Lewis (2016, p. 137) resume alguns dos resultados encontrados por Amos Tversky, psicólogo israelense responsável por estudos revolucionários sobre a tema da tomada de decisão:

As pessoas diziam coisas estranhas. Por exemplo, diziam que magenta era similar a vermelho, mas que vermelho não era similar a magenta. Amos identificou a contradição e começou a generalizá-la. Perguntava às pessoas se elas achavam que a Coreia do Norte era como a China Comunista. Elas respondiam que sim. Perguntava-lhes se a China Comunista era como a Coreia do Norte - e diziam que não. As pessoas achavam que Tel Aviv era como Nova York, mas que Nova York não era como Tel Aviv. Achavam que o número 103 era um pouco parecido com o número 100, mas que o 100 não se parecia com o 103. As pessoas achavam que um trem de brinquedo era muito parecido com um trem de verdade, mas que um trem de verdade não tinha nada a ver com um de brinquedo. Muitas vezes, achavam que um filho se parecia com o pai, mas, se você lhes perguntasse se o pai se parecia com o filho, apenas olhavam para você de um jeito esquisito.

Este capítulo é dedicado ao estudo da contribuição das ciências cognitivas para a compreensão do raciocínio analógico. Começaremos apresentado pesquisas e experimentos que corroboram a falta de confiabilidade acima citada; mas, em seguida, veremos como os mesmos pesquisadores responsáveis por esses experimentos são categóricos ao realçar a importância do raciocínio analógico para a cognição - e, especialmente para o tema desta tese, veremos como o raciocínio analógico é importante para a linguagem. Ao final deste capítulo,

${ }^{41}$ É curioso notar como Hobbes faz uso de uma analogia para criticar o uso de analogias ("é o mesmo que perambular entre inúmeros absurdos..."). Mais um exemplo da força da analogia. 
conseguiremos compreender o motivo da proximidade entre a analogia e a interpretação extensiva.

\section{1}

\section{Manipulados por uma analogia}

É possível observar, nas últimas décadas, um aumento no interesse pelo estudo da analogia por parte da ciência cognitiva. Vários cientistas e professores se voltaram para o tema, cujas pesquisas e experimentos permitem uma melhor compreensão sobre o assunto. Entre esses pesquisadores, o nome de Douglas Hofstadter é comumente citado. Em um livro (escrito em coautoria com o professor de psicologia Emanuel Sander) publicado em 2013, há uma pergunta cuja resposta pode lançar luz sobre a irracionalidade do raciocínio analógico: "É possível que analogias tenham o poder de nos manipular, de nos torcer em torno de seus dedinhos?" (2013, p. 257).

A resposta é positiva. Segundo eles, uma simples analogia pode enquadrar a nossa compreensão das situações, moldando, consequentemente, as nossas percepções, raciocínios e decisões. Em resumo: as analogias podem nos manipular. Como?

Nesse contexto, há dois sentidos para a palavra "manipulação". Ambos os sentidos se complementam.

Em primeiro lugar, a manipulação pode se dar pela forma como as analogias surgem em nossas mentes de forma aleatória e, ao que parece, injustificada. Estamos caminhando pela rua, pensando em alguma coisa qualquer e - de repente e sem ter sido convidada - surge uma analogia: um pensamento nos leva para outro, que leva para outro, assim 
sucessivamente, sem que haja uma relação lógica entre eles. Ao fim, quando nos damos conta do quão distante está o nosso pensamento, nos perguntamos: "por que estou pensando nisso?".

As associações que fazemos são aleatórias e, exatamente por isso, difíceis de acompanhar. É como se as analogias tivessem vontades próprias que não conseguimos compreender.

Um exemplo desse processo cognitivo pode ser útil para realçar as suas perplexidades. No romance "Capturado", o escritor Henry Green mostra, ao narrar em terceira pessoa os pensamentos de uma personagem, a forma aleatória como fazemos associações:

No número 15, quando Trant saiu do alojamento, sua mulher prometeu que faria uma torta de carne de porco para o jantar. Isso o fez lembrar do suboficial que tinha sido alvo de risadas no dia anterior, correndo feito uma galinha degolada, com os auxiliares dele feito um bando de gansos tontos (GREEN, 2016, p. 90).

Por que uma torta de carne de porco o fez lembrar-se do suboficial que foi alvo de risadas no dia anterior? Qual a relação entre eles? Henry Green não faz o menor esforço para explicar ao leitor o porquê dessa associação. Mas é exatamente essa ausência de explicação que demonstra o poder de Henry Green enquanto escritor - ou seja: enquanto observador da condição humana. Ele não explica porque nem nós sabemos como explicar quando isso acontece conosco. É claro que há alguma relação, alguma semelhança - mas é difícil precisar qual é. O que nos resta é conjecturar, como fez o crítico literário James Wood (2011, p. 84-85) ao discorrer sobre o trecho acima citado:

Bom, por que a torta de carne de porco 'lembrou Trant' do episódio anterior? O máximo que podemos fazer é supor que Trant pensa algo do gênero: "torta de carne de porco... porco morto... quintal de sítio... galinhas correm depois de mortas... aquela maldita confusão de ontem quando meu pessoal ficou correndo feito galinha degolada". (...) Mas talvez a cabeça de Trant não funcionasse assim. Talvez tenha pensado: "torta de carne de porco... maldita confusão de ontem... como uma galinha degolada" - nessa ordem? 
O trecho do romance de Henry Green é interessante por mostrar como a analogia, ao surgir em nossas mentes sem ter sido convidada, pode nos manipular - pois, complementando o primeiro sentido para a palavra "manipulação", há ainda o segundo: a forma como somos "coagidos" pelas analogias, forçando uma determinada linha de raciocínio.

Mais um exemplo da literatura. Em um trecho do romance "Ulysses" - famoso pela densidade e complexidade da escrita -, uma personagem (Leopold Bloom) está se aproximando de um pub. Enquanto se aproxima, seguem observações sobre o que a personagem está vendo - o pó de chá que esguicha da porta aberta, os jatos de gengibre. Mas, entre as frases, há uma especialmente enigmática: "Da grade do porão fluía flutuante o jorro choco da pórter" (JOYCE, 2012, p. 167).

Jorro choco da pórter? O que é isso? O que a personagem está vendo?

James Joyce, o autor do romance, revolucionou o gênero ao levar às últimas consequências a inovação introduzida por Gustave Flaubert no século XVIII: a fusão entre aquilo que o autor narra e aquilo que a personagem pensa, a ponto de o leitor ficar em dúvida sobre quem está fazendo determinada observação. É o chamado estilo indireto livre ${ }^{42}$, ou "tensão entre o estilo do autor e o estilo dos personagens" (WOOD, 2012, p. 42).

Quando o leitor lê a frase "Da grade do porão fluía flutuante o jorro choco da pórter", James Joyce quer induzir a dúvida: Quem está observando isso? Joyce ou Leopold Bloom? E ele faz isso porque quer se aprofundar na psicologia dos personagens, mas sem dá-la de bandeja ao leitor: cabe ao leitor aprender a "ler" o livro para, ao mesmo tempo, "ler" os

\footnotetext{
42 "Ele olhou a esposa. É, ela estava tediosamente infeliz de novo, quase doente. Que raio diria ele?" é o exemplo utilizado pelo crítico literário James Wood (2012, p. 21) para explicar o estilo indireto livre. "O pensamento ou discurso interior do marido não tem mais a sinalização autoral; não há 'ele disse a si mesmo' nem 'imaginou' ou 'pensou'. Vejam o ganho de flexibilidade. A narrativa parece se afastar do romancista e assumir as qualidades do personagem, que agora parece 'possuir' as palavras. O escritor está livre para direcionar o pensamento informado, para dobrá-lo às palavras do personagem".
} 
personagens. Mas o controle é dele; o leitor tem a liberdade para interpretar o que quiser, mas tal interpretação é, de certa forma, direcionada pelas palavras escolhidas. E James Joyce sabe como ninguém fazer uso das palavras certas.

No trecho em questão, a personagem está se aproximando de um pub. Pórter pode, portanto, se referir ao tipo de cerveja - escura, com leve sabor amargo. Um jorro choco? Que fluía flutuante?

Será que a personagem está vendo alguém urinando?

Pelo uso das palavras e contexto, James Joyce quer que o leitor faça as associações necessárias para enxergar não somente o que a personagem enxerga, mas também pela forma como ela enxerga. James Joyce está manipulando o leitor, forçando uma leitura específica.

É dessa forma que as analogias nos manipulam: fazendo o nosso pensamento ir por determinado caminho. Como colocam Hofstadter e Sander (2013, p. 257), "elas moldam nossas interpretações de situações e determinam as conclusões dos argumentos. Dito de outra forma, uma analogia não se contentará em simplesmente prejudicar a festa; depois que aparecer, ditará o resto da noite".

É claro que a palavra "manipulação" remete, inicialmente, a algo negativo. Ninguém gosta de ser manipulado, seja lá por o quê/quem for. Mas nem sempre o resultado será negativo. "Ser cutucado, empurrado ou mesmo forçado por uma analogia pode, obviamente, ter consequências ruins, mas esse é o outro lado de um fenômeno que é amplamente positivo" (HOFSTADTER e SANDER, 2013, p. 257).

Outra comparação muito comum, ao menos na cultura ocidental, é aquela que relaciona moralidade à limpeza. Ser limpo é ser moral. É possível observar essa relação em inúmeras instâncias. Uma delas é a linguagem. São inúmeros os exemplos de fala que fazem essa correlação. "Ele está envolvido em um lamaçal de corrupção"; "o filho do nosso vizinho só usa linguagem suja"; "deixe de lado esses pensamentos 
impuros"; "você está arrastando alguém para a lama"; "não suje a reputação dela"; "lave essa boca suja".

É difícil afirmar categoricamente qual é a razão para essa correlação ou porque ela é tão forte. Mas, provavelmente, a explicação repousa na religião. No cristianismo, o batismo cumpre exatamente essa função: a de lavar os pecados da pessoa. E são vários os trechos da Bíblia que associam moralidade à limpeza: Atos 22:16 ("Levanta-te, batiza-te e lava os teus pecados"), Salmos 51:2 ("Lava-me de toda a minha culpa e purifica-me do meu pecado"), João 13:8 ("Disse-lhe Pedro: 'Senhor, jamais me lavarás os pés!' Ao que Jesus the advertiu: 'Se eu não lavar os teus pés, tu não terás parte comigo"').

Essa correlação é tão forte que um dos grandes conhecedores da psicologia humana a incluiu em um trecho importante de uma das suas peças. Em "Macbeth", Shakespeare narra a história do general do exército do Rei da Escócia que, após ouvir uma profecia de três bruxas, busca assassinar o rei para começar um novo reinado. Depois que ele leva a cabo o homicídio do rei, a sua esposa, Lady Macbeth, é consumida pela culpa. Para tentar amenizar esse sentimento, ela tenta se lavar, tentando desesperadamente retirar uma mancha de sangue que tem na mão. "Sai, mancha maldita! Sai, estou dizendo! (...) Aqui está, ainda agora, este fedor de sangue. Nem todos os perfumes das Arábias conseguirão perfumar esta mãozinha" (SHAKESPEARE, 2017, p. 106).

A referência à peça de Shakespeare não é aleatória; ela foi a inspiração para os experimentos que obtiveram o maior êxito em comprovar como podemos ser manipulados pelas analogias. Os resultados desses experimentos estão descritos no artigo "Washing Away Your Sins: Threatened Morality and Physical Cleasing" (2006) ${ }^{43}$. Nele, os

43 É importante deixarmos registrado que experimentos posteriores não conseguiram replicar os resultados do artigo citado (FAYARD, BASSI, BERNSTEIN e ROBERTS, 2009; EARP, EVERETT, MADVA e HAMLIN, 2014). Apesar disso, apresentamos os resultados dessa pesquisa porque esses experimentos posteriores não comprovaram a inexistência do "efeito Macbeth"; eles só demonstraram essa a descoberta do artigo citado não pode ser dada como certa. 
autores (os psicólogos Cheng-Bo Zhong e Katie Liljenquist) buscaram demonstrar o quão profundamente essa relação (entre moralidade e limpeza) está incorporada na psique das pessoas em um nível inconsciente. O primeiro experimento consistia em um simples exercício. Para um grupo de pessoas, eles pediram para elas pensarem em alguma ação cometida no passado, mas com uma condição: eles deveriam lembrar uma ação ruim. Para outro grupo de pessoas (o grupo de controle), também foi pedido para pensarem em alguma ação cometida no passado, qualquer ação. Depois, cada participante recebeu uma folha com algumas palavras, sendo que algumas letras estavam em branco: W _ $\mathrm{S}, \mathrm{S} \mathrm{H} \mathrm{H}_{-} \mathrm{E} \mathrm{R}, \mathrm{S}_{\text {_ }} \mathrm{P}$. O primeiro grupo, que precisou lembrar ações ruins, completou os espaços em branco formando palavras que remetiam à limpeza, como "wash" (lavar), "shower" (chuveiro) e "soap" (sabão). Já o segundo grupo, que teve a liberdade para pensar em qualquer ação passada, formou palavras emocionalmente neutras, como "wish" (anseio), "shaker" (sacudir) e "step" (degrau).

Esses resultados refletem o que os autores chamam de "Efeito Macbeth": a exposição às indiscrições morais próprias ou de outra pessoa reflete uma ameaça moral que estimula a necessidade de limpeza física (ZHONG e LILJENQUIST, 2006, p. 1452). Da mesma forma como Lady Macbeth, que tenta se lavar para expulsar o sentimento de culpa pelo assassinato do Rei da Escócia, também recorremos (nem que seja ao menos em pensamento) à limpeza moral quando diante de imoralidades. É como se a pessoa se "sujasse" ao pensar em algo errado.

O segundo experimento tenta avançar ainda mais na forma inconscientemente relacionamos limpeza e moralidade. Dessa vez, todos os participantes tinham que lembrar de algo ruim ou reprovável que haviam feito no passado. Em seguia, metade dos participantes receberam lenços umedecidos antissépticos, possibilitando a limpeza das mãos; a outra metade não recebeu nada. Por fim, perguntaram a cada participante se eles estariam dispostos a ajudar um aluno que estava com problemas. O resultado: os participantes que não receberam os lenços umedecidos 
estavam significativamente mais propensos a ajudar um desconhecido do que aqueles que haviam limpado as mãos. Os autores do experimento buscavam testar a eficácia da limpeza física. Seria possível "lavar os pecados morais"? Conjecturando a partir dos resultados alcançados, é como se a limpeza física "purificasse" a pessoa, eximindo-a da responsabilidade de ajudar um desconhecido.

Todos esses exemplos, casos e experimentos, apesar das diferenças entre eles, realçam 0 poder das analogias. Somos constantemente manipulados pelas analogias que surgem (induzidas ou inconscientes) em nossas mentes. Como afirmam Hofstadter e Sander (2013, p. 257), “a interpretação de uma situação é inseparável das analogias (ou categorias) que evoca".

No dia 11 de outubro de 2006, na cidade de Nova York, um avião colidiu com um enorme prédio. É muito provável que qualquer pessoa que tenha recebido essa notícia no momento do acidente tenha se lembrado da destruição das Torres Gêmeas no dia 11 de setembro de 2001. Seria um absurdo presumir que se tratava de um novo atentado terrorista? Hofstadter e Sander dizem não; na verdade, essa presunção seria extremamente lógica (tanto o é que a bolsa de valores Dow Jones caiu após o anúncio da colisão). Mas, apesar da tragédia, não se tratava de outro atentado terrorista. Foi, na realidade, um acidente aéreo como vários que, infelizmente, acontecem todos os anos. Um avião monomotor que transportava duas pessoas perdeu o controle e colidiu com um prédio residencial de 42 andares; somente as duas pessoas que estavam dentro do avião morreram (NEWMAN e RASHBAUM, 2006).

Apesar da enorme diferença entre os desastres, a comparação com a tragédia do dia 11 de setembro é inevitável. "A analogia com os eventos de 11 de setembro ocorre imediatamente, colorindo profundamente a percepção que se tem do evento" (HOFSTADTER e SANDER, 2013, p. 297). Em razão do trauma do atentado contra as Torres Gêmeas, não foram poucos aqueles que pensaram em ataque terrorista no dia 11 de outubro de 2006. 


\section{2}

\section{Somos realmente tão superficiais?}

As analogias são fluidas. E essa fluidez pode ser percebida a partir de uma constatação que pode parecer, ao menos em um primeiro momento, paradoxal: não só podemos ser influenciados pelas analogias, como também podemos (facilmente) manipular uma analogia.

E por que é tão fácil construir analogias? Porque realizamos analogias com base em semelhanças meramente superficiais. Hofstadter e Sander: "Se fosse pedido aos psicólogos que trabalham com analogia para nomear a descoberta experimental mais sólida em sua disciplina, certamente o vencedor de uma pesquisa desse tipo seria a noção de que as características superficiais são a chave para a recuperação da memória" (2013, p. 337).

Afirmação semelhante também pode ser encontrada no livro "Analogies at War" (1992), do cientista político Yuen Khong. No livro, Khong estuda as razões que levaram os líderes americanos a tomarem as decisões que foram tomadas durante a Guerra da Vietnã. Estudando as justificativas que foram utilizadas, ele percebe como o raciocínio analógico era um recurso retórico comum; em inúmeras ocasiões, uma analogia histórica era utilizada para justificar uma decisão do presente. Um exemplo: um dos conceitos mais utilizados pelos líderes norteamericanos e analistas políticos favoráveis à Guerra do Vietnã era o conceito da "Teoria do Efeito Dominó". O próprio nome da teoria remete, por si só, a uma analogia. A primeira vez que ela foi utilizada foi no auge da Guerra Fria, quando o então presidente norte-americano Dwight Eisenhover afirmou que, se um país caísse sob a influência do comunismo, então, consequentemente, todos os países ao redor também 
cairiam - como peças de dominó. Posteriormente, a mesma teoria foi utilizada para justificar a invasão ao Vietnã, mas com um reforço: a comparação com um precedente histórico - no caso, os eventos ocorridos durante a década de 30 e que tornaram a Segunda Guerra Mundial inevitável. A invasão japonesa da Manchúria (1931), a invasão da Etiópia pela Itália de Mussolini (1935), a remilitarização da Renânia pelas tropas alemãs de Hitler (1936), a fracassada Conferência de Munique (1938), a ocupação nazista da Tchecoslováquia (1939) - cada evento sendo uma peça em uma fileira de dominós, com a queda de uma levando à queda da seguinte, assim sucessivamente, até a queda da última peça: $1^{\circ}$ de setembro de 1939, início da invasão alemã à Polônia, o começo da Segunda Guerra Mundial. Ao justificar a invasão do Vietnã através da "Teoria do Efeito Dominó" e da comparação com os eventos que levaram à Segunda Guerra Mundial, os líderes norte-americanos queriam passar a ideia de que a derrota para o Vietnã seria o primeiro passo para um conflito ainda maior (KHONG, 1992, p. 58-59).

Um observador externo, com distanciamento histórico, poderia supor que essa retórica não foi bem-sucedida. Afinal, a comparação para um tanto quanto exagerada; tal comparação confere uma proporção superestimada a ameaça do Vietnã, levando a crer, inclusive, que uma derrota poderia levar ao início de uma terceira guerra mundial.

Entretanto, apesar do exagero dessa comparação, ela exerceu uma influência considerável em uma parcela da população norteamericana. Por quê? Como uma comparação descomedida conseguiu ser eficaz?

A explicação, é claro, não é tão simples. Mas um dos fatores - que explicam não só o sucesso dessa analogia, mas de tantas outras - está relacionada às sólidas descobertas experimentais sobre analogia que foram citadas acima por Hofstadter e Sander. Em um dos capítulos do seu livro, Khong resume as descobertas realizadas por pesquisadores no campo da psicologia do raciocínio analógico, e afirma: "Uma das descobertas mais interessantes dos pesquisadores que trabalham na solução analógica de problemas é que as pessoas escolhem analogias 
com base em similaridades superficiais entre o analógico em perspectiva e a situação que ela deveria iluminar" (KHONG, 1992, p. 217).

Essa constatação - a de que realizamos analogias com base em semelhanças meramente superficiais - leva Hofstadter e Sander ao seguinte questionamento (2013, p. 337): nós, seres humanos, somos realmente tão superficiais?

Todas as referências às citadas "descobertas experimentais sólidas" levam, inevitavelmente, ao artigo "The Mechanisms of Analogical Learning" (1989), de Dedre Gentner.

"Uma coisa nos lembra outra" (GENTNER, 1989, p. 199). Assim tem início o artigo, demonstrando o poder das lembranças espontâneas e o importante papel desempenhado pelo raciocínio analógico. E continua: "A experiência mental é cheia de momentos em que uma situação atual nos lembra de alguma experiência anterior armazenada na memória. Às vezes, esses lembretes levam a uma mudança na maneira como pensamos sobre uma ou ambas as situações" (GENTNER, 1989, p. 199).

Como exemplo, ela cita uma história envolvendo a filha de um amigo. Apesar de muito nova (3 anos de idade), Heida, a filha do amigo, já havia viajado para vários países (ela nasceu nos Estados Unidos). Certo dia, na Turquia, ela comentou com os pais após ouvir o latido de um cachorro: "Os cães da Turquia fazem o mesmo som que os cães na América. Talvez todos os cães o façam. Será que os cães da Índia fazem o mesmo som?" Para chegar a tal percepção, uma criança de 3 anos de idade teve que relacionar uma série de situações diferentes. Talvez o seu raciocínio tenha seguido essa linha: primeiro, ela teve que comparar pessoas de diferentes países para perceber que elas falam diferente umas das outras; depois, ela teve que comparar cães de diferentes países; por fim, para dar significado a sua observação sobre cães, ela traçou um paralelo entre os sons emitidos por homens e pelos cães: ao ir de país para país, as pessoas parecem diferentes, mas os cães soam iguais. Apesar da pouca idade, suas experiências - e, mais importante, as relações entre essas experiências - levaram a uma grande compreensão 
sobre a diferença entre a linguagem humana e os sons dos animais (GENTNER, 1989, p. 199).

Ao longo da vida, nos deparamos com inúmeras situações e, para cada uma, precisamos atribuir um significado. Quando se é uma criança, com toda a vida pela frente, as situações que aparecem são novas; tudo é novidade. Quando não se é mais uma criança, as situações que aparecem não são novas; algumas até podem ser, mas a maioria não é. Quando se é uma criança, atribuir um significado a uma nova situação é um desafio, pois são poucas as experiências disponíveis; quando não, é mais fácil, pois há uma abundância de experiências. Para um adulto, o fato de pessoas de diferentes países falarem línguas distintas chega a ser tão banal que nem é digno de nota. Para uma criança de três anos, chegar a tal compreensão é quase como uma aventura. Adulto ou criança, não importa - as lembranças espontâneas de experiências passadas são aliadas importantes na nossa forma de entender o mundo à nossa volta. Como? "Lembranças espontâneas podem nos levar a fazer novas inferências, descobrir uma abstração comum ou, como aqui, perceber uma diferença importante entre duas situações parcialmente semelhantes" (GENTNER, 1989, p. 199-200). Nessa resposta já é possível reparar que a busca por semelhanças (ou, podemos dizer, um raciocínio analógico) exerce uma função.

Que função é essa? Qual é a importância dessa função?

Para responder tais perguntas, Dedre Gentner se propõe a rastrear o processo cognitivo que começa com a lembrança inicial (esse cachorro faz o mesmo que um cachorro de outro país) até o armazenamento final de algumas novas informações (à medida que você passa de país para país, as pessoas parecem diferentes, mas os cães parecem iguais). No meio do caminho, algo importante acontece: percebe-se uma diferença entre situações semelhantes (ou uma semelhança entre duas situações diferentes).

Como raciocinamos por analogia? Gentner apresenta a seguinte proposta: “(a) acessar o sistema básico; (b) realizar o mapeamento entre 
a base e o alvo; (c) avaliar a partida; (d) armazenar inferências no alvo; e (e) extrair o princípio comum" (GENTNER, 1989, p. 226). Em seguida, questiona: o que governa o acesso espontâneo a situações semelhantes ou análogas?

Um experimento (GENTNER, 1989, p. 226-228) teve como objetivo investigar respostas para essa pergunta. Tal experimento foi projetado para se parecer com o acesso natural à memória de longo prazo. Nele, os participantes recebiam 18 histórias (curtas, de um parágrafo cada) para ler. Abaixo, uma dessas histórias:

\begin{abstract}
Karla, um velho falcão, morava no topo de um carvalho alto. Uma tarde, ela viu um caçador no chão com um arco e algumas flechas rudes que não tinha penas. $O$ caçador mirou e atirou no falcão, mas errou. Karla sabia que o caçador queria suas penas, então ela deslizou até o caçador e se ofereceu para lhe dar algumas. O caçador ficou tão agradecido que prometeu nunca mais atirar em um falcão. Ele saiu e matou um cervo.
\end{abstract}

Uma semana depois, os participantes recebiam um novo conjunto de 18 histórias para ler; e, em seguida, Ihes eram entregues a seguinte instrução: se alguma das novas histórias os lembrasse de alguma das histórias originais, eles deveriam tentar reescreve-las da forma mais fiel possível, de memória.

Cada nova história tinha uma história original correspondente. Elas não eram iguais, mas sim semelhantes em alguns pontos; e havia uma gradação de semelhança: algumas das novas histórias tinham uma "mera semelhança" com a original, outras constituíam uma "verdadeira analogia", e havia ainda as que eram "falsas analogias". Partindo da história original transcrita acima, suas correspondências nas novas histórias eram as seguintes:

\footnotetext{
Verdadeira analogia

Havia um pequeno país chamado Zerdia que aprendeu a fabricar o computador mais inteligente do mundo. Um dia, Zerdia foi atacado por seu vizinho bélico, Gagrach. Mas os mísseis foram mal direcionados e o ataque falhou. $O$ governo zerdiano percebeu que Gagrach queria computadores zerdianos, por isso se ofereceu para vender alguns de seus computadores para o país. O
} 
governo de Gagrach ficou muito satisfeito. Prometeu nunca mais atacar Zerdia.
Mera aparência
Certa vez, houve uma águia chamada Zerdia que doou algumas suas penas para um esportista, para que ele prometesse nunca atacar águias. Um dia, Zerdia estava aninhado no alto de um penhasco quando viu o esportista chagando com uma besta. Zerdia voou para encontrar o homem, mas ele o atacou e a derrubou com uma única flecha. Quando ela caiu no chão, Zerdia percebeu que a flecha tinha suas próprias penas.

\begin{abstract}
Falsa analogia
Havia um pequeno país chamado Zerdia que aprendeu a fabricar o computador mais inteligente do mundo. $\mathrm{O}$ Zerdia vendeu um de seus supercomputadores ao seu vizinho, Gagrach, para que eles prometessem nunca mais atacar Zerdia. Mas um dia Zerdia foi surpreendido por um ataque supresa de Gagrach. Enquanto capitulava, o governo aleijado de Zerdia percebeu que os mísseis haviam sido guiados por supercomputadores zerdianos.
\end{abstract}

A primeira das novas histórias representa uma "verdadeira analogia" da história original; apesar das mudanças de nomes e objetos, as histórias são praticamente as mesmas. Na segunda história, há uma "mera semelhança"; há algumas semelhanças com a original (águias e penas), mas elas são muito diferentes. E na terceira história há uma "falsa analogia".

Das 18 novas histórias que cada participante recebeu, 1/3 era das histórias que representavam "verdadeiras analogias" com a original, 1/3 de "meras semelhanças" e 1/3 de "falsas analogias".

Diante desse cenário, é razoável supor que o participante que lesse uma nova história que fosse uma "verdadeira analogia" conseguirá lembrar a história original com mais facilidade e fidelidade. Os resultados, entretanto, mostraram que essa suposição está equivocada. Na verdade, as histórias do tipo "mera semelhança" foram as que mais ajudaram o participante a acessar a memória da história original.

Eles [os participantes dos experimentos] eram muito mais propensos a recuperar correspondências superficiais. Com as [histórias] de "mera semelhança", os sujeitos conseguiram acessar a história original $78 \%$ das vezes, enquanto as "verdadeiras analogias" só conseguiram 
acessar apenas $44 \%$ das vezes, e as "falsas analogias" em $25 \%$ das vezes. Todas as três diferenças foram significativas, sugerindo que as semelhanças superficiais têm o papel mais importante no acesso da memória (GENTNER, 1989, p. 228).

Esse experimento corrobora a ideia de que realizamos analogias com base em semelhanças meramente superficiais.

Outros experimentos foram realizados, replicando os resultados alcançados. Um deles foi conduzido pelo psicólogo Thomas Gilovich. No artigo "Seeing the past in the presente: The effect of associations to familiar events on judgementes and decisions" (1981), Gilovich afirma que, quando tomamos uma decisão em situação de incerteza, não enxergamos o novo dilema como se fosse completamente novo; ao contrário, conectamos os novos dilemas com decisões e eventos do passado, pois as informações, estratégias e cursos de ação utilizados podem ser úteis na solução do problema que se apresenta. "Formamos associações entre circunstâncias existentes e situações passadas e somos influenciados pelo que consideramos serem as implicações desses eventos passados" (GILOVISH, 1981, p. 797).

Entre os experimentos conduzidos para demonstrar a influência da associação a experiências passadas e conhecimentos genéricos na tomada de decisão, um é especialmente pertinente (GILOVISH, 1981, p. 802-808). Ele envolve a solução de um problema hipotético na área da política externa.

Essa área oferece um campo fértil para associações e analogias porque a preparação acadêmica de quem pretende entrar e fazer carreira em um órgão governamental dedicado à política externa envolve o estudo de decisões anteriores. Consequentemente, a decisão a ser tomada em relação a um novo problema será influenciada pelo sucesso ou fracasso de uma decisão passada. No caso da política externa norte-americana, dois eventos históricos são significativos: a "política de apaziguamento" em relação à agressiva política expansionista de Hitler e o envolvimento no Vietnã. É comum encontrar, na história americana, governantes fazendo alusões a um desses eventos para justificar uma decisão de política externa. Gilovish cita (1981, p. 802) uma fala do presidente Harry 
Truman; quando tenteou explicar o porquê dos E.U.A. terem ajudado a Coreia do Sul durante a Guerra da Coreia, Truman fez uma analogia com a segunda guerra mundial: segundo ele, o comunismo estava agindo na Coreia da mesma forma como Hitler e Mussolini estavam agindo na Europa.

Mas há um problema. Os dois eventos históricos podem ser utilizados para propor cursos de ação completamente distintos. Tanto a forma como os E.U.A. lidaram inicialmente com a ameaça nazista como a forma escolhida para enfrentar o problema do Vietnã são vistas, em retrocesso, como fracassos - só que por motivos diferentes. No primeiro caso, o erro estava relacionado a uma omissão; no segundo caso, o problema estava na ação. Diante dessas duas leituras possíveis, será possível manipulá-las de forma a manipular a decisão de uma pessoa?

Os participantes do experimento (42 alunos matriculados na disciplina de Ciência Política na Universidade de Stanford) receberam um texto que narrava uma crise de política externa. Também foram informados que o caso era hipotético e que não tinha qualquer relação com crises reais do presente ou do passado. A seguir, Ihes era pedido recomendações sobre como resolver tal crise hipotética.

Um pequeno Estado democrático, $B$, estava sofrendo ameaças de um Estado vizinho de fronteira, totalitário e agressivo, A. O Estado A enviou uma quantidade massiva de tropas para a fronteira com o Estado $B$, tornando o conflito iminente. Diante de tal ameaça, o Estado B requisitou ajuda aos E.U.A. Todos os 42 participantes receberam esse mesmo caso hipotético, mas foram elaborados três textos descrevendo a crise, todos contendo as mesmas informações básicas, com exceção de algumas frases que não alteravam em nada o entendimento do caso mas que tinham a intenção de sugerir uma analogia com alguma crise do passado. Um texto continha frases que sugeriam uma analogia com a Segunda Guerra Mundial (por exemplo: a sala aonde as informações eram repassadas era chamada "Winston Churchill Hall"); outra sugeria uma analogia ao Vietnã (a sala era chamada "Dean Rusk Hall", uma alusão ao Secretário de Estado norte-americano durante a Guerra do Vietnã); e o último texto continha frases neutras (“Abraham Lincoln Hall”). 
Depois que todos os alunos apresentaram uma recomendação de ação, suas respostas foram classificadas em uma escala de 1 a 9 , sendo 1 = apaziguamento e 9 = intervenção militar. O resultado: os participantes que receberam os textos que sugeriam uma analogia com a Segunda Guerra Mundial apresentaram recomendações pró-intervenção, enquanto os participantes cujos textos sugeriam uma analogia com o Vietnã apresentaram recomendações pró-apaziguamento.

Esse resultado demonstra não só o quão importantes são as experiências passadas e o conhecimento geral para a tomada de decisão - ele também demonstra como utilizamos analogias específicas baseadas em semelhanças de relevância questionável (GILOVISH, 1981, p. 807).

Escolhemos analogias com base em similaridades superficiais segundo Douglas Hofstadter e Emmanuel Sander (2013, p. 339), esse é um fenômeno confirmado por um grande número de estudos, e não pode haver dúvidas quanto à exatidão das descobertas.

De fato, estudos experimentais demonstram que os indivíduos que apresentam uma situação de origem e que recebem uma situação de destino geralmente não conseguem ver nenhuma conexão entre os dois, a menos que compartilhem características no nível da superfície. Além disso, em tais experimentos, quando duas situações têm uma semelhança superficial, a segunda invariavelmente traz à mente a primeira, independentemente de ser apropriada ou não (ou seja, independentemente de haver razões mais profundas para conectar os dois casos). Por exemplo, se os sujeitos abordarem primeiro um problema aritmético referente a itens comprados em uma loja, qualquer outro problema relacionado a compras lembrará instantaneamente o problema inicial. Mas se o tema do primeiro problema for manipulado experimentalmente - digamos que seja uma visita a um consultório médico em vez de uma loja -, os participantes quase certamente não verão nenhum vínculo entre as duas histórias, mesmo se o método de solução do primeiro problema se aplicar perfeitamente para o segundo problema.

Em resumo: na cognição, o superficial sempre vence. Essa afirmação tem consequências poderosas. Da mesma forma como a teoria econômica clássica partia do pressuposto que nós, seres humanos, só tomamos decisões de forma extremamente racional, toda a literatura 
dedicada aos argumentos por analogia também dá a entender que o raciocínio analógico que desempenhamos diariamente (as semelhanças que utilizamos para conectar duas situações distintas) é perfeitamente racional no sentido de que não nos deixamos influenciar por qualquer semelhança - no sentido de que, quando raciocinamos analogicamente, buscamos semelhanças que estão na essência das situações em debate. Mas tais experimentos demonstram que isso não é correto. Não é porque uma noz se parece com um cérebro que afirmamos que o segundo tem o mesmo sabor que o primeiro. De acordo com os esquemas de argumentação por analogia (seja indutivo ou dedutivo), não basta apontar a existência de uma ou mais semelhanças; é necessário argumentar que tais semelhanças são relevantes, que elas justificam a correspondência que se quer traçar.

Mas o que todos os experimentos apontam é o contrário dessa imagem perfeitamente racional. Em geral, nos atentamos ao superficial e isso basta. A força do superficial nos leva a acreditar que tudo que reluz é ouro, que ver uma andorinha significa a chegada da primavera, que os livros são julgados por suas capas (HOFSTADTER e SANDER, 2013, p. 338).

$E$, quando atentamos para as analogias que fazemos, percebemos esse padrão. Todos os exemplos utilizados nas páginas anteriores dessa tese demonstram isso. Seja um ministro do Supremo Tribunal Federal, uma filósofa ou o Presidente dos Estados Unidos da América: encontramos uma semelhança meramente superficial e automaticamente já damos a analogia como justificada. Essa constatação corrobora a afirmação de Shecaira e Struchiner, já citada, segundo o qual "os autores de argumentos analógicos nem sempre formulam princípios explicitamente; quando muito, eles explicam em que são semelhantes as duas situações, a original e a debatida" (2016, p. 117).

Todas as descobertas citadas corroboram as críticas que são usualmente direcionadas ao raciocínio analógico. Elas demonstram que a falta de confiabilidade que intuitivamente enxergamos na analogia não é injustificada. Mas, ao mesmo tempo, há uma questão paradoxal: os 
próprios autores dessas pesquisas não hesitam em defender o raciocínio analógico. O raciocínio analógico é de fundamental importância para os processos cognitivos - inclusive para a interpretação do direito.

Como diz o provérbio alemão: não jogue o bebê fora junto com a água do banho.

\section{3}

\section{O combustível e o fogo do pensamento}

No início do já citado "Surfaces and Essences: Analogy as the Fuel and Fire of Thinking", Hofstadter e Sander (2013, p. 3) afirmam que "sem conceitos não pode haver pensamento, e sem analogia não pode haver conceitos"

É comum relacionarmos os conceitos àquilo que encontramos nos dicionários (HOFSTADTER e SANDER, 2013, p. 3). Afinal, quando queremos encontrar o significado (ou o conceito, podemos dizer) de uma palavra, recorremos ao dicionário, que nos dará uma lista de significados associados à palavra buscada. A palavra "banda", por exemplo. Uma ida ao dicionário dará os significados: faixa contínua de frequência para transportar dados ("banda-larga de internet"), referência a um pedaço ou metade ("eu comi uma banda daquela laranja"), localidade ("o sítio do meu tio fica lá para aquelas bandas"), o golpe em que se usa o pé para derrubar alguém ("dei uma banda naquele sujeito"), banda musical ("os Beatles é a minha banda preferida"). Ocorre que essa ida ao dicionário, apesar de comum, pode dar uma impressão errada dos conceitos: a de que todos os significados são claramente distintos um do outro. Nada mais distante da realidade, pois todos esses significados não só se confundem, mas também se aprofundam internamente. Os dicionários passam uma falsa ideia de simplicidade quando, na verdade, deveriam deixar o leitor consciente da complexidade inerente à tarefa de conceituar 
uma palavra. A complexidade se dá tanto em um sentido horizontal quanto em um sentido vertical: horizontal porque os diferentes significados podem se confundir, e vertical porque de um único significado pode se expandir outros diferentes significados. A palavra "banda" pode significar banda musical; mas o próprio significado de "banda musical" se subdivide em inúmeros significados que, por sua vez, podem ser facilmente confundidos: banda de rock, de jazz, de música clássica, de samba, reggae etc. E essas subdivisões, por sua vez, também geram outras subdivisões - rock clássico, rock instrumental, rock alternativo, rock de garagem etc. As possibilidades são infinitas. O leitor, ao recorrer a um dicionário, pode terminar a leitura com a impressão de completude quando, na realidade, deveria ficar desesperado com as infinitas possibilidades que se abrem. Os dicionários escondem o fato de que cada palavra possui um número ilimitado de significados (HOFSTADTER e SANDER, 2013, p. 5). ${ }^{44}$

Apesar disso, há uma impressão transmitida pelos dicionários que é importante, e que releva muito sobre o nosso processo cognitivo: as categorizações. Quando os dicionários apresentam diferentes significados para as palavras, forma-se a ideia de categorias. Para cada palavra há diversas categorias de significados. Categorizar é um processo importante, pois nos ajuda a compreender o que se passa ao nosso redor. Categorizamos porque isso nos ajuda a pensar. Um exemplo. É razoável supor que ninguém discordaria da afirmação de que "é errado agredir uma pessoa". Mas, quanto mais pensamos sobre essa afirmação, percebemos o quanto ela nos ensina sobre o comportamento humano, pois há agressões e agressões. Há aquelas agressões que repreendemos de forma enfática, mas há aquelas que não repreendemos de forma tão enfática (como o do jovem que perde a paciência e bate no colega de classe que the fez bullying durante um ano inteiro) e até mesmo aquelas que muitos acreditam ser justificadas (como a do pai que mata o estuprador da sua filha). Como entender essa aparente contradição?

${ }^{44}$ Hofstadter e Sander não chegam a citar expressamente, mas essas reflexões sobre dicionários e a infinidade de significados expressam a característica da textura aberta da linguagem, exposta na seção 3.2 deste trabalho. 
Categorizar é uma forma de colocar ordem naquilo que parece ininteligível. Existe a agressão ofensiva e a defensiva, a agressão contra um predador e contra alguém da mesma espécie, a agressão premeditada e a impulsiva, a agressão emocional e aquela realizada a sangue-frio, a agressão maternal... A lista é imensa (SAPOLSKI, 2017, p. 15-18). Mas, através dessas categorias, compreendemos melhor porque algumas agressões são mais repreendidas que outras; compreendemos melhor o comportamento humano. Conforme Hofstadter e Sander (2013, p. 15):

Em resumo, a categorização ininterrupta é tão indispensável à nossa sobrevivência no mundo quanto a batida ininterrupta de nossos corações. Sem o batimento cardíaco pulsante e incessante de nosso "mecanismo de categorização", não entenderíamos nada ao nosso redor, não poderíamos raciocinar de forma alguma, não poderíamos nos comunicar com mais ninguém e não teríamos base para tomar qualquer ação.

Dada a importância da categorização para o pensamento, convém perguntar: como elas são originadas? Não há consenso em relação à resposta dessa pergunta. O psicólogo John Robert Anderson apresenta, no artigo "The Adaptive Nature of Human Categorization" (1991, p. 410411), três hipóteses constantemente citadas na literatura dedicada ao tema. A primeira é a chamada "Origem linguística": aqui, um rótulo linguístico é criado e as pessoas começam a perceber que um grupo é criado dentro desse rótulo. Como nos dicionários: uma palavra é criada e as pessoas começam e enxergar vários objetos ou situações que são representados por essa palavra, criando, assim, um grupo. A segunda hipótese é conhecida como "sobreposição de recursos": quando as pessoas percebem que vários objetos se sobrepõem, elas acabam criando uma categoria para incluí-los. Um exemplo (moderno) é a categoria que ficou conhecida como "Filmes da Marvel", criada para englobar filmes que não só possuem personagens criados nas revistas em quadrinhos de uma empresa específica (a Marvel), mas que compartilham também uma linguagem cinematográfica parecida. A terceira hipótese diz respeito à "Função semelhante": quando as pessoas percebem que vários objetos, apesar de distintos, cumprem funções 
semelhantes, é criada uma categoria para englobá-los. As cadeiras, por exemplo; apesar de não serem exatamente iguais (elas podem variar no formato, material, tamanho, número de pernas), todas compartilham da mesma característica funcional: a de servir como assento.

Apesar da falta de consenso quanto à origem das categorias, John Robert Anderson afirma que isso não chega necessariamente a ser um problema, pois as três hipóteses não são antagônicas; ao contrário, elas cumprem funções semelhantes. "A categorização é justificada pela observação de que os objetos tendem a se agrupar em termos de seus atributos, sejam eles recursos físicos, rótulos linguísticos, funções ou qualquer outra coisa" (ANDERSON, 1991, p. 411). E como diferentes objetos são agrupados na mesma categoria? Qual é o ponto em comum entre as três hipóteses apresentadas? "Se a categorização é central para o pensamento, qual mecanismo a realiza? Analogia é a resposta" (HOFSTADTER e SANDER, 2013, p. 15).

Seja a "origem linguística", "sobreposição de recursos" ou "função semelhante", todas elas operam através da analogia: o que justifica a presença de objetos distintos na mesma categoria é a existência de algum ponto em comum. É fácil perceber o raciocínio analógico operando nas duas últimas hipóteses - os "filmes da Marvel" possuem personagens em comum e as cadeiras compartilham uma característica funcional semelhante -, mas e no caso da "origem linguística"? Como o raciocínio analógico opera no nível da linguagem?

Para responder a essa pergunta, Douglas Hofstadter parte de outra, que é uma dúvida comum: "Por que os bebês não se lembram dos eventos que aconteceram com eles?" (HOFSTADTER, 2001, p. 500). O seu palpite, longe de querer esgotar o assunto ou oferecer uma resposta definitiva, é a de que os conceitos que os bebês dispõem para dar sentido ao que acontece ao seu redor ainda são muitos incipientes. Desde o início deste capítulo os termos "fazer sentido do mundo", "encontrar ordem do caos" e outros similares estão sendo utilizados para descrever o processo 
cognitivo. Mas o que eles realmente querem dizer? Como "fazemos sentido do mundo" e "encontramos ordem do caos"?

Segundo Hofstadter e Sander (2013, p. 33), somos constantemente confrontados com um número indefinido de situações sobrepostas e entrelaças, e conseguimos encontrar um sentido nesse caos através de conceitos. Palavras e conceitos surgem espontaneamente à mente para nos ajudar a compreender o que se passa na nossa frente; quanto maior o estoque de palavras e conceitos, quanto maior for a "caixa de ferramentas", mais fácil será a compreensão do que estamos vendo ou sentindo. Quando uma mulher coloca a mão na barriga e diz para um homem "tenho uma notícia maravilhosa", palavras e conceitos surgem em nossa mente para entender o que está se passando ("casamento", "gravidez"); talvez essa impressão não corresponda com o que realmente está se passando entre aquelas duas pessoas - pode ser que o motivo da felicidade não seja a existência de uma criança, mas sim a ausência dela -, mas não importa, pois palavras e conceitos serão usados da mesma forma. Mas uma criança, ao ver uma mulher colocando a mão na barriga e dizendo "tenho uma notícia maravilhosa", terá enorme dificuldade para entender o que está acontecendo. $E$ isso se dá em razão da falta de palavras e conceitos suficiente para fazer sentido do que está vendo (Por que ela está colocando a mão na barriga? Ela está com dor de barriga? E por que isso seria uma notícia maravilhosa?).

Romancistas adoram fazer uso dessa falta de palavras e conceitos nas crianças para mostrar como o ponto de vista adotado por elas difere dos adultos. O romance "Pelos olhos de Maisie", de Henry James, escrito com base nessa premissa; ao narrar em terceira pessoa a história de um mesquinho divórcio, Henry James consegue apresentar diferentes pontos de vista - do pai, da mãe e da filha -, deixando o leitor tão confuso quanto a pequena Maisie fica ao ser jogada de uma casa para a outra, e testemunhando situações que ela não consegue entender (mas que o leitor sim). Como escreveu o crítico James Wood (2011, p. 24), "James quer que o leitor compartilhe a confusão da menina, e quer também 
descrever a corrupção dos adultos vista pelos olhos da inocência infantil". Outro romancista que fez uso desse elemento foi Neil Gaiman; no romance "O oceano no fim do caminho", escrito em primeira pessoa por uma criança, há um trecho no qual ela espia o pai com a babá em um cômodo da casa enquanto a mãe está fora, a trabalho.

Eu ia correr, simplesmente sair correndo, mas havia uma luz acesa na sala de estar, aonde nós, crianças, nunca íamos, o cômodo revestido com painéis de carvalho reservado apensas a ocasiões e pessoas especiais.

As cortinas estavam fechadas. Eram de veludo verde com forro branco, e a luz que escapava por elas, no vão em que não haviam sido puxadas até o fim, era amarela e suave.

Eu não tinha certeza do que estava vendo. Meu pai imprensava Ursula Monkton contra a lareira enorme que ficava na parede do outro lado da sala. Ele estava de costas para mim. Ela também, as mãos apoiadas na grande moldura da lareira, lá no alto. Ele a segurava por trás. A saia mídi dela estava levantada até a cintura.

Não sabia exatamente o que eles estavam fazendo, e na verdade não queria saber, não naquela hora (GAIMAN, 2013, p. 94).

Ela pode não saber o que eles estavam fazendo, mas, para o leitor, não há dúvidas. Neil Gaiman continua brincando com isso durante todo o romance, até o momento em que o escancara perto do fim, quando a criança diz "Eu adorava a sonoridade das palavras, mesmo não tendo muita certeza do significado de todas elas" (2013, p. 154).

"A vida é um jogo de xadrez, e os bebês são como iniciantes, olhando para uma cena complexa em um tabuleiro, sem ter a menor ideia de como organizá-los" (HOFSTADTER, 2001, p. 501). Quanto mais o tempo passa, mais fácil é fazer sentido sobre o que está acontecendo não só porque ganhamos experiência ou vivência, mas porque a caixa de ferramentas que contém as palavras e conceitos, vazia no início da vida, vai aumentando ao englobar outras palavras e conceitos, construindo, assim, um enorme reportório, com conceitos cada vez maiores. 
E como os conceitos vão "engordando"? Mais uma vez, a analogia é a resposta.

A palavra "mãe", por exemplo. Uma criança, ao pensar sobre o conceito de mãe, projetará a imagem da sua própria mãe (Mãe é quem dá à luz, que cria ou criou um ou mais filhos). Anos depois, ao se deparar com outra criança brincando com uma boneca, dando-lhe uma mamadeira e trocando a sua roupa, pensará algo nesse sentido: ela toma conta da boneca da mesma forma como a minha mãe cuida de mim. (Mãe é quem dispensa cuidados maternos, que protege, que dá assistência a quem precisa). O conceito de mãe foi ampliado, graças a um raciocínio analógico que comparou duas situações e visualizou, ali, semelhanças.

Não é nosso objetivo aqui apresentar uma teoria definitiva do crescimento do conceito específico de mãe, já que o nosso objetivo é mais geral do que isso. O que estamos propondo é que o nascimento de qualquer conceito ocorre mais ou menos como descrito acima. No início, há uma situação concreta com componentes específicos, e, portanto, é percebida como algo único e claramente separável do resto do mundo. No entanto, depois de um tempo - talvez um dia depois, talvez um ano -, alguém se depara com outra situação que se considera semelhante e é feita uma ligação. A partir desse momento, as representações mentais das suas situações começam a ser conectadas, a se confundirem, dando origem a uma nova estrutura mental que, embora seja menos específica do que qualquer uma de suas duas fontes (menos detalhadas, por exemplo), não é fundamentalmente diferente deles (HOFSTADTER e SANDER, 2013, p. 35).

Hofstadter e Sander podem não ter a intenção de apresentar uma teoria definitiva, mas suas observações estão em harmonia com pesquisas que demonstram a importância do raciocínio analógico para o desenvolvimento da linguagem (FAUCONNIER e TURNER, 2002; GENTNER, 2003; ITKONEN, 2005). Tais pesquisas buscam comprovar a afirmação de Quine de que "não há nada mais básico para o pensamento e a linguagem humana do que nosso senso de similaridade" (1969, p. 116). 
Da mesma forma como os conceitos que uma pessoa dispõe para compreender o mundo ao seu redor vão sendo ampliados com o passar dos anos, o mesmo pode ser dito da linguagem (entendida aqui de forma abstrata). Como o exemplo do "Oxford English Dictionary" - que teve uma primeira versão com poucos volumes, uma segunda versão muito maior, e que hoje é uma obra aberta em constante atualização - demonstra, a linguagem expande com o tempo. O tamanho do "Oxford English Dictionary" aumentou com o passar dos anos não somente porque melhoramos o nosso poder de adquirir conhecimento, mas, principalmente, porque novas palavras e significados foram surgindo ao longo dos séculos, décadas e anos, sendo incorporados à linguagem. Várias palavras e significados dos dicionários atuais seriam irreconhecíveis para alguém que viveu há dois séculos; da mesma forma como, para nós, seriam irreconhecíveis palavras e significados constantes de um dicionário escrito no ano de 2300 - pois ele englobaria situações que ainda não aconteceram e que, consequentemente, não conhecemos. A linguagem evolui. "Um grupo de seres humanos começa com uma gramática muito simples que, gradualmente, geração após geração, se torna cada vez mais complexa, até atingir o nível que vemos no mundo atual" (FAUCONNIER e TURNER, 2002, p. 171).

Entretanto, surge um problema: a realidade é incomparavelmente mais rica que as formas linguísticas. Fauconnier e Turner (2002, p. 178): "Embora se diga que a linguagem dispõe de um número infinito de formas, é uma infinidade menor do que a infinidade de situações oferecidas pelo riquíssimo mundo físico em que vivemos". Imagine a frase "meu cachorro é marrom" e, em seguida, pense em todas as diferentes situações que ela comporta: as diferentes pessoas, os diferentes cachorros, as diversas tonalidades da cor marrom.

Diante desse problema, como a linguagem consegue evoluir? Como ela consegue abarcar diferentes situações, novos significados e usos distintos a partir das mesmas formas linguísticas? Em outras palavras: se formas linguísticas são fixas e o mundo está em constante 
evolução, e se os conceitos são essenciais para o pensamento, como conseguimos adequar a linguagem a tal evolução?

O linguista americano William Dwigh Whitney afirma que isso só é possível graças à analogia. Segundo ele, "tudo na linguagem passa pela analogia" (2013, p. 150). Um grupo de seres humanos começa com uma gramática simples, com uma semântica ainda restrita; com o passar dos anos, e devido à evolução social/tecnológica, aparecem novas situações que, dada a semelhança com os significados já conhecidos e atrelados a palavras já existentes, começam a ser referidas a partir destas. O conceito se expande por analogia. Talvez o primeiro significado que venha à cabeça de uma cabeça quando ela pensa na palavra "nuvem" diz respeito ao que ele vê quando olha para o céu (um aglomerado de gotas diminutas de água ou de cristais de gelo em suspensão no ar, e que dão origem às chuvas); mas esse significado está longe de esgotar todos os significados atrelados à palavra nuvem: há o significado relacionado a um movimento ou multidão, como quando se diz que há "uma nuvem de mosquitos sobrevoando o poste"; há o significado relacionado à falta de compreensão ("nuvem de ignorância"); e outros que ainda não conhecemos porque ainda irão surgir (conforme explica a textura aberta da linguagem). Apesar dos infinitos significados, é possível observar a existência de semelhanças entre eles. Quando uma pessoa olha para o céu e vê uma nuvem, percebe uma forma branca formada por inúmeras partículas e que Ihe impedem a visão do que está além; e quando ela olha para um enxame de abelhas, voando na mesma direção e em tamanha quantidade que chegam a parecer formar uma massa única, ela também dificulta a visão do que está além; e quando ela percebe que não consegue compreender determinada situação porque há muitos fatores envolvidos que ela ainda não consegue discernir, diz que está em uma "nuvem de ignorância" que a impede de enxergar o quadro inteiro. O fio que permite a ampliação do campo semântica de uma palavra, o fio que une todos esses significados, é a analogia. "A força da analogia é, de fato, uma das mais potentes em toda a história da linguagem; como cria 
classes inteiras de formas, tem poder para mudar seus limites" (WHITNEY, 2013, p. 75).

Há alguns anos um novo significado foi incluído à palavra nuvem: "a computação em nuvem", termo cunhado para retratar o armazenamento de arquivos em servidores remotos que podem ser acessados remotamente através da internet. Por que computação "em nuvem"? Conforme aponta a pesquisa realizada por Antonio Regalado (2011), o termo surgiu pela primeira vez em 1996, em uma reunião da empresa Compaq, e foi utilizado para explicar a criação dessa nova tecnologia que permite a um usuário ter acesso aos seus arquivos mesmo quando não instalados em sua máquina pessoal; e, após isso, o termo foi adotado como uma jogada de marketing, pois, segundo o matemático Reuven Cohen, a nuvem é uma metáfora para a internet. E não é difícil perceber o apelo desse termo. Mesmo aquele que não entende de internet e servidores consegue ter nem que seja uma visão básica da tecnologia quando a visualiza a partir da ideia de uma nuvem. Os próprios funcionários da empresa Compaq, na já citada reunião ocorrida em 1996, desenharam uma nuvem (não muito diferentes das que são desenhadas pelas crianças) em um pedaço de papel para explicar o que estavam propondo. "Computação em nuvem": um novo uso para a palavra nuvem, que, apesar de distinta dos significados citados acima, guarda a sua semelhança para com elas.

Sem analogia não pode haver conceitos. Sem conceitos não pode haver pensamentos. Pelos motivos expostos, para Douglas Hofstadter e Emmanuel Sander, a analogia é o combustível e fogo do pensamento.

Inclusive para a linguagem. 


\section{6}

\section{Analogia e linguagem}

Conforme a textura aberta da linguagem, as palavras possuem infinitos significados. Inicialmente, uma criança compreende o significado de determinada palavra quando percebe que ela é usada para se referir sempre às mesmas situações. Mas, com o passar dos anos, ela percebe que aquela palavra possui outros significados, pois ela começa a ser utilizada para se referir a outras situações, diferentes daquela que já estava acostumada. Como funciona essa descoberta de novos significados?

Uma hipótese: novos significados são adquiridos através do raciocínio analógico. Talvez os diferentes significados das palavras estão baseados nas semelhanças entre as situações às quais elas são utilizadas.

No artigo "Language and the career of similarity" (2001), as psicólogas Dedre Gentner e Mary Jo Rattermann investigam essa hipótese no contexto da aquisição de significados das palavras por parte das crianças. Como elas percebem, por exemplo, que a palavra mãe não é utilizada somente para se referir àquela mulher que esteve sempre ao seu lado, cuidando e amando-a desde o momento em que ela consegue se lembrar?

O vocabulário só começa a se desenvolver quando a criança possui entre um ano e meio e dois anos de idade. (Antes disso, elas vocalizam certos sons em contextos específicos, como o "vrum-vrum" quando estão empurrando um carrinho de brinquedo.) A partir do segundo ano, há um "surto" de vocabulário, especialmente através de substantivos concretos; esse surto é chamado de "insight nominal", quando a criança percebe que cada objeto tem um nome. Lev Vygotsky, citando o psicólogo alemão Wilhelm Stern, afirma que essa é a maior descoberta da vida de 
uma criança (VYGOTSKY, 1986, p. 60). "Assim, a primeira verdadeira conquista semântica de uma criança é extrair e nomear objetos separadamente de seus contextos" (GENTNER e RATTERMANN, 2001, p. 253). Posteriormente, termos relacionais (que expressam noções de tamanho, localização, tempo e quantidade) são incluídos no vocabulário, mas a aquisição do seu significado é demorada: verbos como "ir" e "vir", "derramar" e "encher" e "misturar/mexer" só são corretamente utilizados a partir dos cinco ou seus anos de idade (GENTNER e RATTERMANN, 2001, p. 253-254).

O desenvolvimento da linguagem em uma criança já foi amplamente catalogado pela literatura dedicada ao tema, mas os autores fazem esse breve resumo para, em seguida, afirmar que "parece haver paralelos entre a ordem de aquisição do vocabulário e a programação do desenvolvimento encontrada por similaridade" (GENTNER e RATTERMANN, 2001, p. 255). Ao que parece, é possível traçar um paralelo entre o desenvolvimento da linguagem e o desenvolvimento da capacidade que uma criança possui para compreender semelhanças.

Assim como na linguagem, o desenvolvimento da similaridade em uma criança também é "evolutiva": começa de uma forma precoce e ingênua, posteriormente assumindo uma forma avançada, mais esclarecida (GENTNER e RATTERMANN, 2001, p. 226). Quine expressa essa evolução nos seguintes termos: "Nesta carreira da noção de similaridade, iniciando em sua fase inata, desenvolvendo-se ao longo dos anos à luz da experiência acumulada, passando da fase intuitiva para a semelhança teórica e finalmente desaparecendo por completo" (QUINE, 1969, p. 138).

Inicialmente, o uso da similaridade se manifesta através de correspondências exatas (ou quase exatas) entre todos os aspectos das duas situações, como quando a criança percebe a semelhança entre uma maça na mesa e outra maça na mesa. Em seguida, começa a ocorrer uma diminuição gradual nas correspondências necessárias para se perceber a similaridade; isso ocorre quando a criança percebe a 
semelhança entre a maçã na mesa e a maçã na árvore. O próximo passo envolve a percepção de que atributos de um objeto podem corresponder mesmo quando outras características não coincidem - por exemplo: a semelhança entre uma maça vermelha e um bloco de montar vermelho e também através de correspondências puramente relacionais - por exemplo: a semelhança entre uma maça caindo da árvore e um livro caindo de uma prateleira (GENTNER e RATTERMANN, 2001, p. 228).

Nesse sentido, o desenvolvimento da similaridade em uma criança pode ser descrita da seguinte maneira: primeiro ela percebe semelhanças através da correspondência total entre dois objetos (duas maças idênticas); em seguida, surge a percepção da semelhança que decorre de correspondências parciais (uma maça vermelha e um livro vermelho); e, por fim - completando a transição entre a forma precoce e ingênua para a forma avançada e esclarecida, mais sofisticada -, surgem as semelhanças que decorrem de identidades relacionais (a maça que cai da árvore, permitindo que a vaca a alcance - e o livro que cai da prateleira, permitindo que a criança a alcance) (GENTNER e RATTERMANN, 2001, p. 228).

Comparando o desenvolvimento tanto da similaridade quanto da linguagem com as idades em que se manifestam, as autoras sustentam a existência de um paralelo que fortalece a hipótese que confere ao raciocínio analógico um papel importante no desenvolvimento da linguagem. Consequentemente, a aquisição dos diversos significados de uma palavra também sofre influência do raciocínio analógico.

Para corroborar a afirmação acima, as autoras citam pesquisas que apontam para o fato de que a percepção das crianças para os diferentes significados das palavras se baseia principalmente em semelhanças - em especial semelhanças relacionadas à forma. "Isso sugere que crianças pequenas podem estar operando sob a suposição de que as extensões dos nomes dos objetos são baseadas na semelhança física" (GENTNER e RATTERMANN, 2001, p. 256). 
A relação entre semelhança física e aprendizagem dos significados das palavras pode ser observada no seguinte experimento (GENTNER e RATTERMANN, 2001, p. 256). Um grupo de crianças recebeu dois objetos com formas e funções diferentes: "Jiggy", uma caixa amarela com um rosto que balançava as sobrancelhas quando a criança puxava uma alavanca; e "Zimbo", uma máquina de doces vermelha que liberava bolas de goma quando a criança puxava uma alavanca. Os dois brinquedos foram apresentados às crianças e deixados na sala aonde ocorria o experimento. Após um tempo, quando as crianças já estavam se referindo aos nomes dos brinquedos de forma espontânea, lhes foi mostrado um novo objeto; esse novo objeto era parecido com o "Jiggy", mas, quando a criança puxava a sua alavanca, ele liberava uma bola de goma ao invés de erguer as sobrancelhas. Quando foi pedido às crianças darem um nome para esse novo objeto, mais de $80 \%$ das crianças em estágio préescolar (entre dois e cinco anos) o chamara de "Jiggy"; apesar de o novo objeto compartilhar da mesma função realizada por "Zimbo", a escolha do nome foi baseada em similaridade física. Já as crianças com idade entre cinco e nove anos também nomearam o novo objeto a partir de uma semelhança - mas, nesse caso, uma semelhança baseada na função: cerca de $60 \%$ das crianças chamou o novo objeto de "Zimbo". (Esse experimento, além de demonstrar a relação entre semelhança física e aprendizagem dos significados das palavras, também aponta o desenvolvimento da capacidade de similaridade nas crianças.)

Tais experimentos demonstram a importância do raciocínio analógico para o desenvolvimento da linguagem. Mas o papel desempenhado pelo raciocínio analógico não se resume somente aos significados iniciais que atribuímos às palavras quando somos crianças. Sua importância é constante.

Para demonstrar esse ponto, Hofstadter e Sander (2013, p. 34-38) imaginam um garoto chamado Tim. Do nascimento à idade adulta, Tim será apresentado à "nuvem de conceitos" que a palavra "mãe" possui.

Com 1 ano de idade, a essência do conceito é a sua própria mãe, Sue. Por enquanto, essa categoria ("mãe”) possui um único objeto (Sue) - 
"uma pessoa muito maior do que ele, que o alimenta, o conforta quando ele chora, canta canções de ninar, o pega no colo, brinca com ele no parque e assim por diante". Com 1 ano e meio de idade, Tim está no parque e vê um menino um brincando na caixa de areia. Ao lado desse menino há um adulto, cuidando dele. Tim imediatamente pensa: "Essa pessoa está cuidando do menino da mesma forma como a minha mãe cuida de mim". A categoria ganhou mais um objeto - e não demorará para Tim perceber outras aplicações para esse conceito. Com 6 anos de idade, Tim não terá dificuldade para entender que a cadela Lassie é a mãe do cachorro Spot, mas ficará um pouco confuso ao escutar da sua professora que a abelha rainha é a mãe de todas as abelhas da colmeia. Com 7 ou 8 anos de idade, Tim compreenderá frases nas quais a palavra mãe é utilizada com maior fluidez - como "Maria é a mãe do Senhor Jesus". Com 9 anos, Tim lê em livro sobre o Egito que "Ísis é a mãe da natureza" e, durante toda a adolescência, começa que lidar com frases cada vez mais abstratas: "Maria Curie é a mãe da radioatividade", "a revolução americana é mãe da revolução francesa", "o judaísmo é a mãe do cristianismo", "a alquimia é a mãe da química”. E não para por aí: ao longo da sua vida, Tim irá se deparar com usos para a palavra mãe que desafiam aquele significado original que ele construiu quando tinha 1 ano de idade: "mãe natureza", "empresa mãe", "placa mãe".

A tese defendida por Hofstadter e Sander propõe que o nascimento de qualquer conceito ocorre da forma como descrita acima:

No início, há uma situação concreta com componentes particulares e, portanto, é percebida como algo único e claramente separável do resto do mundo. Porém, depois de um tempo - talvez um dia depois, talvez um ano -, a pessoa se depara com outra situação que se considera semelhante e é feita uma ligação. A partir desse momento, as representações mentais das duas situações começam a se conectar, a se confundir, dando origem a uma nova estrutura mental que, embora seja menos específica do que qualquer uma de suas duas fontes (ou seja, menos detalhada), não é fundamentalmente diferente deles (HOFSTADTER e SANDER, 2013, p. 37). 
E assim sucessivamente. As palavras possuem infinitos significados, existindo, entre todos esses significados, alguma semelhança. Novos significados são apreendidos através de um raciocínio analógico. E aqui, mais vez, podemos observar como o superficial sempre vence. Conforme demonstrado pelos experimentos citados no capítulo anterior, realizamos analogias com base em similaridades superficiais; não estabelecemos um princípio norteador que irá nortear a percepção das similaridades. Assim como na aquisição de novos significados.

Este capítulo foi dedicado ao estudo das contribuições das ciências cognitivas no tocante ao tema da analogia. Através dos diversos experimentos, pesquisas e reflexões que foram realizadas nas últimas décadas, pudemos observar algumas características do raciocínio analógico. Vimos que, quando destacamos as semelhanças entre dois objetos, o superficial exerce uma poderosa influência: escolhemos analogias com base em similaridades que são superficiais. Essa constatação fornece mais uma munição para aqueles que acusam o raciocínio analógico (e suas demais ramificações) de ser efêmero e instável. Quando as semelhanças são infinitas e quando somos fortemente influenciados por semelhanças superficiais, a volatilidade se faz presente. E vimos também que, apesar dessa volatilidade, os cientistas cognitivos são unânimes quando afirmam que o raciocínio analógico é um processo cognitivo fundamental - na compreensão do mundo à nossa volta, na busca por sentido diante das mais diferenças experiências e, em especial (levando em consideração as finalidades da presente tese), no desenvolvimento da linguagem e na aquisição de novos significados. É impossível elencar todos os usos e significados da palavra "mãe"; eles são infinitos. Mas entre todos esses usos e 
significados - os conhecidos e os ainda desconhecidos - há uma conexão que se justifica em razão de alguma semelhança. Ou seja: ampliamos o campo semântico das palavras por meio de um processo cognitivo que funciona através de sucessivas analogias.

Tais características também permitem constatações importantes para o direito - e, em específico, para a distinção entre analogia e interpretação extensiva.

Qualquer tentativa de se estabelecer critérios objetivos para a relevância ou justificativa de semelhança precisa enfrentar o fato de que analogias são construídas com base em semelhanças superficiais - o que não é nada fácil de enfrentar. Somos fortemente influenciados por analogias superficiais.

Isso corrobora a afirmação de estudiosos da teoria da argumentação no sentido de que os argumentos analógicos raramente explicitam o princípio utilizado para aferir as similaridades realçadas. Demonstrando que o superficial sempre vence, o mais comum é ver o autor de um argumento analógico tão somente explicando as semelhanças em jogo.

E a descoberta da importância do raciocínio analógico para a expansão dos significados das palavras nos permite responder à primeira das duas perguntas formuladas introdução desta tese: em que reside a semelhança entre a analogia e a interpretação extensiva?

Apesar de todas as distinções apresentadas pela doutrina brasileira (que serão enfrentadas detidamente no próximo capitulo), não são raras as confusões que surgem quando tais técnicas são expostas/discutidas. É comum nos depararmos com variações da seguinte frase: analogia e interpretação são técnicas que, apesar da proximidade, são distintas. Mas em que reside essa proximidade? Já observamos anteriormente que ambas as técnicas são utilizadas para a solução de casos que não são explicitamente regulados pelo direito. Essa semelhança, entretanto, não é suficiente para explicar as constantes confusões; ela é muito superficial. 
Não - para explicar tamanha confusão, a proximidade entre ambas as técnicas deve ser mais profunda.

O que, então? Ora, o raciocínio analógico. Tanto a analogia quanto a interpretação extensiva buscam, a partir de um raciocínio analógico, solucionar casos que não são explicitamente reguladas pelo direito.

Que um jurista faz uso de um raciocínio analógico na analogia, não há dúvida. Isso é facilmente perceptível no próprio conceito (em um contexto jurídico) de analogia: atribuir a um caso não regulamentado pelo direito a mesma disciplina conferida a um caso semelhante já regulamentado. A comparação entre duas situações (uma regulada e outra não regulada) está na própria essência desse processo.

Mas o mesmo também ocorre na interpretação extensiva. Nela, o jurista também faz uso de um raciocínio analógico. Afinal, o que possibilita a expansão do campo semântico das disposições legais é o raciocínio analógico. Da mesma forma que o garoto Tim no primeiro ano de idade (que, ao ver um adulto cuidando de outra criança no parque, alarga o sentido da palavra mãe), um jurista também procede de forma semelhante ao realizar uma interpretação extensiva. As tentativas de explicação da interpretação extensiva sempre realçam o fato de ser um processo interpretativo, atuando somente no nível da semântica. Mas essa é uma visão incompleta, porque o processo cognitivo desempenhado em tal atividade interpretativa é analógica. Existe a fonte e existe o alvo; a fonte é aquela situação ou significado que claramente está abarcada pela norma jurídica; o alvo é a situação ou significado não claramente regulada, em que se questiona se ela pode ser abarcada pelo campo semântico da norma jurídica. Nessa operação, serão destacadas as semelhanças entre a fonte e o alvo - e é essa percepção das similaridades envolvidas que irá justificar a interpretação extensiva. Como no crime de fraude em certame de interesse público (art. 311-A do Código Penal), já discutido no quarto capítulo desta tese. Quando o referido artigo estabelece a proibição da utilização ou divulgação de conteúdo sigiloso de concurso público, tal proibição engloba a cola eletrônica? A fim de se justificar essa extensão, o jurista terá em mente uma situação origem (a divulgação prévia, de forma não pública e com a finalidade de beneficiar 
poucas pessoas, de temas específicos que serão cobrados na prova) e, a partir daí, traçará semelhanças com a situação alvo (a cola eletrônica). Foi exatamente o que fez Ministro do STJ Reynaldo Soares da Fonseca quando realizou interpretação extensiva do art. 311-A do Código Penal de forma a enquadrar a cola eletrônica na tipificação legal.

A interpretação extensiva atua por meio de um raciocínio analógico. Percebemos os diferentes usos e significados das palavras por meio de um raciocínio analógico. Essas considerações são sustentadas pelas pesquisas produzidas no campo da ciência cognitiva nas últimas décadas; mas, justiça seja feita, já era possível vislumbrar a importância do raciocínio analógico diante da multiplicidade — ou, melhor dizendo, infinitude - de significados das palavras quando Hart discorre sobre a textura aberta da linguagem e a diferença entre a zona de certeza e a zona de penumbra - "(...) a pessoa encarregada de responder não tem outra alternativa senão a de examinar se o caso presente se assemelha 'suficientemente' ao caso simples sob os aspectos 'pertinentes"' e "a pessoa decide acrescentar um caso novo a uma sucessão de outros, devido a semelhanças que podem ser razoavelmente consideradas pertinentes do ponto de vista jurídico e suficiente próximas do ponto de vista factual" (2009, p. 64-65). Ou quando Wittgenstein fala em "semelhança de família"45.

45 "Considere, por exemplo, os processos que chamamos de "jogos". Quero dizer, jogos de tabuleiro, de carta, com bola, de combate, e assim por diante. O que todos eles têm em comum? - Não diga: "Tem que haver para eles algo em comum, senão eles não se chamariam "jogos"” - mas veja se todas as coisas são comuns para eles. - Pois se você os examina, não vai ver, na realidade, algo que todos têm em comum, mas semelhanças, parentescos, e, na realidade, toda uma série dessas coisas. Como foi dito: não pense, veja! - Examine, por exemplo, os jogos de tabuleiro com os seus múltiplos parentescos. Passe agora para os jogos de carta: aqui você encontra muitas correspondências com aquela primeira classe, mas muitos traços comuns desaparecem e outros surgem. Se nós agora passamos para os jogos com bola, então muitas coisas em comum ficam preservadas, mas muitas se perdem. - Eles são todos 'divertidos'? Compare xadrez com jogo do moinho. Ou há em qualquer lugar um ganhar e perder, ou uma competição de jogadores? Pense no jogo de paciência. Nos jogos com bola há ganhar e perder; mas quando uma criança arremessa a bola na parede e a pega de novo, então esse traço se perde. Veja que papel cumprem a habilidade e a sorte. E como é diferente a habilidade no jogo de xadrez e no jogo de tênis. Pense agora nas brincadeiras de roda: Aqui está o elemento da diversão, mas quantos dos outros traços característicos são 
Como se vê, analogia e interpretação extensiva possuem mais semelhanças do que aparentam em um primeiro momento. Resta saber se as distinções se justificam.

perdidos! E assim podemos percorrer muitos, muitos outros grupos de jogos. Ver surgir e desaparecer semelhanças. E o resultado dessa consideração é agora: vemos uma complicada rede de semelhanças que se sobrepõem e se cruzam mutuamente. Semelhanças no grande e no pequeno" (WITTGENSTEIN, 2017, p. 60-62). "Eu não poderia caracterizar melhor essas semelhanças do que pela expressão "semelhanças de família"; pois assim se sobrepõem e se cruzam as distintas semelhanças que têm lugar entre os membros de uma família: altura, traços faciais, cor dos olhos, andar, temperamento etc., etc. - E eu direi: os 'jogos' conformam uma família." (WITTGENSTEIN, 2017, p. 62). 
O resto é ruído: analogia e interpretação extensiva em lide

Recapitulando, as principais diferenças comumente citadas entre analogia e interpretação extensiva podem ser resumidas em dois pontos. (i) A aplicação da analogia pressupõe a existência de uma lacuna jurídica, enquanto na interpretação extensiva ocorre exatamente o contrário (existe norma jurídica reguladora, mas ela terá que ter o seu campo semântico expandido). (ii) Consequentemente, na analogia, há a criação de uma nova norma, enquanto na interpretação extensiva aplica uma norma jurídica já existente, decidindo sobre o seu significado.

Este capítulo, o último da tese, irá investigar essas diferenças para, ao fim, responder à segunda pergunta proposta na introdução: os critérios de distinção usualmente apontados se sustentam?

Para tanto, iremos aprofundar o estudo de um caso que já foi citado brevemente no terceiro capítulo: o caso "Rádio do Vaticano". Esse caso é um ótimo exemplo para testarmos os limites da distinção entre analogia e interpretação extensiva. 


\section{1}

\section{O caso "Rádio do Vaticano"}

Relembrando: o art. 674 do Código Criminal italiano apresenta sanções para o "arremesso perigoso de coisas"; as torres de transmissão do Vaticano emitem ondas eletromagnéticas que, conforme sustenta a peça acusatória do Ministério Público, ameaçam a saúde daqueles que moram nas proximidades; então, a pergunta que se apresenta é: a emissão das ondas eletromagnéticas proveniente das torres de transmissão do Vaticano pode ser enquadrada no ilícito tipificado no art. $674 ?$

A Corte de Cassação italiana entendeu que sim (decisão n. ${ }^{\circ}$ 36845/2008), e fundamentou a decisão através da interpretação extensiva do art. 674 do Código Criminal.

Damiano Canale e Giovanni Tuzet propõem uma análise dessa decisão, partindo do seguinte questionamento: "a decisão do tribunal foi realmente o resultado de uma extensão interpretativa do dispositivo legal ou foi, então, um resultado oculto de um raciocínio analógico?" (CANALE e TUZET, 2014, p. 234).

Segundo os autores, o caso da "Rádio do Vaticano" levante dois problemas interpretativos: (1) qual é o significado de "arremessar" e (2) qual é o significado de "coisas". (Esses dois problemas decorrem da própria argumentação utilizada pela Corte de Cassação, que, para definir o alcance semântico da expressão "arremesso perigoso de coisas", procurou inicialmente investigar o significado de cada uma das palavras contidas no termo. $)^{46}$

\footnotetext{
${ }^{46}$ No artigo "Literal Meaning" (1979), John Searle afirma que é possível procurar o significado de uma sentença através de duas estratégias: determinar primeiro o significado de cada uma das palavras contidas na sentença para, depois, agrupá-las no intuito de compreende o significado da sentença; ou o contrário determinar primeiro o significado da sentença para, daí, extrair o significado de cada uma das palavras.
} 
Canale e Tuzet (2014, p. 234) começam afirmando que, segundo o uso linguístico padrão, ondas não são "coisas”. Como sustentar, então, que ondas eletromagnéticas são "coisas"?

A argumentação do Ministério Público fez referência a outro artigo do Código Penal italiano: o art. 624, que dispõe que, para os fins do direito penal, a eletricidade e qualquer outra energia que tenha um valor econômico também são consideradas coisas móveis. Logo, uma interpretação sistemática ${ }^{47}$ sustenta que, conforme o direito penal italiano, ondas eletromagnéticas também são consideradas como "coisas". A defesa argumentou que, em 1930, ano em que o Código foi promulgado, a palavras "coisas" fazia referência tão somente as coisas materiais excluindo da incidência da norma, portanto, as ondas eletromagnéticas.

$\mathrm{Na}$ primeira argumentação (Ministério Público), a interpretação extensiva do art. 674 é justificada através de uma interpretação sistemática. Na segunda argumentação (Defesa), a possibilidade de uma interpretação extensiva é rechaçada a partir do momento em que se afirma que o campo semântico da palavra "coisas" não é amplo a ponto de englobar as ondas eletromagnéticas; e, implícito nessa argumentação, está a constatação de que o único meio legítimo para visualizar ondas eletromagnéticas como "coisas" seria através da analogia, e não da interpretação extensiva (CANALE e TUZET, 2014, p. 234).

Quanto ao significado de "arremessar", o Ministério Público argumentou que a palavra deve ser interpretada de forma extensiva, pois há, nos usos da linguagem, situações que a palavra "emissão" é formulada no sentido de um arremesso (como nas frases "arremessar luz" ou "arremessar suspeita" sobre alguma coisa). A defesa, por outro lado, argumentou o contrário: no uso da linguagem padrão, "arremessar" envolve algum esforço físico, como na frase "arremessar um tijolo contra uma janela".

\footnotetext{
${ }^{47}$ Para Juarez Freitas (1994, p. 53), a interpretação sistemática deve ser definida "como uma operação que consiste em pretender atribuir a melhor significação, dentre várias possíveis, aos princípios, às normas e aos valores jurídicos, hierarquizando-os num todo aberto, fixando-lhes o alcance e superando antinomias, a partir da adequação teleológica, tendo em vista solucionar os casos concretos". Em outras palavras, uma norma jurídica não deve ser interpretada de forma isolada, mas sempre à luz de todo o ordenamento jurídico.
} 
Conforme já foi adiantado, a Corte de Cassação julgou procedente o pedido formulado pelo Ministério Público, inserindo, no ilícito tipificado no art. 674, a emissão de ondas eletromagnéticas advindas do Vaticano. No tocante ao significado da palavra "coisas", a Corte corroborou a interpretação extensiva sustentada pelo Ministério Público e, no tocante ao significado da palavra "arremessar", entendeu, contrariando o que foi argumentado pela defesa, que o uso padrão da palavra não pressupõe, necessariamente, o esforço físico. Nesse último ponto, a Corte utilizou como fundamento alguns versos do poeta Dante Alighieri. ${ }^{48}$

Expostos os argumentos suscitados no caso "Rádio do Vaticano", Damiano Canale e Giovanni Tuzet afirmam que, apesar do que foi expressamente disposto na decisão da Corte, "está longe de ficar claro que a decisão foi resultado de uma interpretação extensiva e não de uma extensão não declarada por analogia" (2014, p. 235).

O principal motivo para essa dificuldade reside em um dos grandes problemas que envolvem o método da interpretação extensiva: não há método. Ou seja: a doutrina não apresenta qualquer critério ou orientação para o uso da interpretação extensiva por parte dos intérpretes do direito, que ficam como que à deriva em uma embarcação desprovida de âncora. A falta de critérios ou orientações (a falta de uma âncora, por assim dizer) abre a possibilidade para utilizações equivocadas da interpretação extensiva. A proposta de Canale e Tuzet é "arremessar uma luz" em cima dessas questões.

Em primeiro lugar, a interpretação extensiva pressupõe a vagueza de uma norma jurídica. Como foi dito no segundo capítulo dessa tese, a interpretação extensiva (assim como a analogia) é utilizada quando a norma jurídica não fornece uma resposta clara e imediata para o problema em questão. "Uma interpretação extensiva é possível se, e somente se, o dispositivo normativo interpretado admitir mudanças nos

\footnotetext{
48 "Agora você pode se perguntar se um verso de um poeta que viveu oito séculos atrás está entre os usos que determinam as interpretações possíveis de um dispositivo normativo controverso nos dias de hoje" (CANALE e TUZET, 2014, p. 235).
} 
casos em que ela pode ser aplicada" (CANALE e TUZET, 2014, p. 236). O que significa dizer: a utilização da interpretação extensiva pressupõe a existência de casos fronteiriços.

A existência de casos fronteiriços (na linguagem e no direito) é explicitada pela ideia da textura aberta da linguagem. Graças a ela, sabemos que as normas jurídicas possuem zonas de certeza e de penumbra, sendo que esta aparece quando há bons argumentos tanto para a aplicação quanto para a não aplicação da norma em determinado caso concreto (SCHAUER, 2009, p. 20). Nesse sentido, o artigo 674 do Código Penal italiano fornece um exemplo tão bom de textura aberta quanto a hipotética "É proibida a entrada de veículos no parque".

Ambos os argumentos apresentados no caso "Rádio do Vaticano" são juridicamente válidos; não é porque os argumentos da defesa falharam em convencer a Corte de Cassação que eles serão considerados inválidos ou ruins. Da mesma forma como existem bons argumentos a favor e contra a interpretação que entende serem os skates veículos, há bons argumentos a favor e contra a interpretação que insere as ondas magnéticas emitidas pelo Vaticano na proibição que sanciona o "arremesso perigoso de coisas".

Na opinião do tribunal, não está imediatamente claro se o
termo "coisas" se aplica às ondas eletromagnéticas, nem
se a palavra "arremesso" se aplica à sua emissão.
Consequentemente, o artigo 674 do Código Penal italiano
é vago: não é definitivamente verdade que ondas
eletromagnéticas são coisas nem que não são; da
mesma forma, não é definitivamente verdade que a
emissão de ondas seja uma espécie de arremesso ou
que não seja. (CANALE e TUZET, 2014 , p. 236

Aliados à textura aberta da linguagem, Canale e Tuzet (2014, p. 237) apresentam o que eles chamam de "Esquema da vagueza" (representado na figura abaixo). 


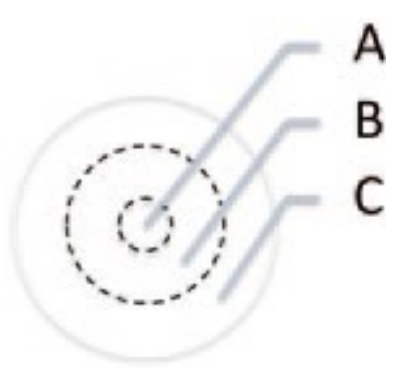

Figura 1 - Esquema da vagueza

$\mathrm{Na}$ figura acima, "A" representa o conjunto de casos que claramente são identificados como inseridos no campo semântico da palavra; "C", por sua vez, representa o conjunto de casos que claramente não são identificados como inseridos no campo semântico da palavra; e, por fim, "B" representa o conjunto de casos fronteiriços, nos quais pairam dúvidas sobre o seu pertencimento ou não ao campo semântico da palavra.

Exemplificando com base na famosa regra hipotética formulada por Hart, vejamos como seria o "Esquema da Vagueza" para a palavra "veículo", objeto de tanta controvérsia. Um carro estaria inserido no conjunto "A", pois ele é claramente identificado como sendo um veículo; um guarda-chuva pertence ao conjunto " $\mathrm{C}$ ", pois não há quem o reconheça como sendo um veículo; já o skate e a bicicleta estariam inseridos no conjunto " $\mathrm{B}$ ", pois há dúvidas quanto a sua identificação como veículo.

"Quando x é um caso fronteiriço, a tarefa da interpretação jurídica é determinar se $\mathrm{x}$ deve ser tratado como um caso 'positivo' ou 'negativo' do ponto de vista jurídico" (CANALE e TUZET, 2014, p. 236). Se o intérprete entender que o caso $\mathrm{x}$ deve ser tratado de forma positiva, então a fronteira entre "A" e "B" será expandida de forma a abarcar o caso $\mathrm{x}$; se entender o contrário, a fronteira entre " $\mathrm{B}$ " e " $\mathrm{C}$ " será retraída de forma a inserir o caso x no conjunto "C".

O "esquema da vagueza" formulado por Canale e Tuzet não difere muito da exposição feita por Hart no sétimo capítulo do livro "O Conceito de Direito". Após discorrer sobre o fenômeno da textura aberta da linguagem, Hart aprofunda as consequências para o direito (um caminho 
natural, pois, se a textura aberta é uma característica indelével da linguagem, e se não há direito sem linguagem, então, consequentemente, a textura aberta também será uma característica indelével do direito). $\mathrm{Na}$ interpretação jurídica, o intérprete poderá se deparar com duas situações: os casos fáceis (inseridos na zona de certeza, quando o caso ou claramente se aplica à norma jurídica ou claramente não se aplica) e os casos difíceis (inseridos na zona de penumbra, quando há dúvidas quanto à aplicabilidade da norma ao caso concreto). Os casos fáceis não demandam muito do intérprete - afinal, a norma fornece uma resposta clara, seja ela positiva ou negativa. Já os casos difíceis são desafiadores para o intérprete; além de exercer o poder discricionário, decidindo se o caso está ou não inserido na hipótese de incidência da norma, o intérprete deverá apresentar uma argumentação que sustente essa escolha. Para Canale e Tuzet (2014, p. 237), a tarefa do intérprete, quando diante de um caso difícil/fronteiriço, é decidir se o caso em questão (que inicialmente está inserido no conjunto "B") deve ser alocado no conjunto "A" ou "C". 49

Qual é o impacto do "esquema da vagueza" para as discussões envolvendo a analogia e a interpretação extensiva? Segundo os autores, se o caso x está localizado em "B", então é possível incluí-lo no âmbito de aplicação da norma através de uma interpretação extensiva; mas, se o caso está localizado em "C", não é possível justificar o uso de uma interpretação extensiva. Isso significa que, caso x esteja localizado em "C", é impossível para o intérprete incluir o caso x no âmbito da aplicação da norma jurídica? Não - ele poderá fazer isso, só que não através de uma interpretação extensiva; ele terá que recorrer a outra técnica, como, por exemplo, a analogia. Se o caso x está localizado em "C", então o intérprete reconhece que a norma jurídica em debate não fornece uma resposta; ele reconhece, na ausência de uma norma que forneça uma resposta, que o caso x representa uma lacuna jurídica; mas que, dadas as semelhanças juridicamente relevantes entre o caso $x$ e os demais

49 "Ao interpretar a previsão legal para fins decisórios, o juiz é chamado para estabelecer esses limites e determinar onde o caso em questão está localizado. Como resultado, após a interpretação jurídica, $x$ deve ser qualificado como pertencente a A ou C" (CANALE e TUZET, 2014, p. 237). 
casos claramente regulados pela norma (aqueles que estão inseridos no conjunto "A"), é justificável utilizar a norma para regular o caso $\mathrm{x}$ (CANALE e TUZET, 2014, p. 237).

Nesse sentido, o que irá separar a analogia da interpretação extensiva é o fato da controvérsia jurídica em questão estar localizada em "B" ou "C". 50 Estando localizada em "B", é possível solucionar a controvérsia por meio de uma interpretação extensiva; se localizada em "C", é possível solucionar por meio da analogia.

Esse quadro compõe o que eles irão chamar de "o problema da localização": "se tivéssemos critérios para localizar um determinado caso dentro de "A", "B" ou "C", seria possível determinar sob quais condições a interpretação extensiva é admitida e a extensão analógica não" (CANALE e TUZET, 2014, p. 237).

O "esquema da vagueza" permite visualizar os desafios da distinção entre a analogia e a interpretação extensiva; e, ao mesmo tempo, esclarece a afirmação de Dimitri Dimoulis citada nas primeiras páginas dessa tese: "A analogia começa onde termina a possibilidade de interpretação extensiva". Ou - e podemos colocar nesses termos -, a analogia começa quando o caso em questão adentra o domínio do conjunto "C". Existindo critérios que permitam determinar se o caso está inserido em "B" ou "C", é possível demarcar uma linha que separe a analogia da interpretação extensiva. A grande questão é: é possível encontrar tais critérios?

Para responder a essa pergunta, os autores fazem uso do conceito de "tolerância semântica". Alguns termos vagos (como "coisas" e "arremessar") permitem alterações em seus significados, englobando, assim, outras situações que não são imediatamente reconhecidas. Por exemplo: entende-se "coisa" como um bem móvel que existe, como, por exemplo, um tijolo ("joguei um tijolo no caso de outra pessoa"). Mas esse significado não é fixo: ele é "tolerante" ao reconhecer outras situações,

50 Se ela estiver localizada em "A", não será necessário recorrer à analogia ou à interpretação extensiva - nesse caso, basta aplicar a norma através de uma simples subsunção. 
outros significados. Como quando se reconhece a energia elétrica como coisa ("a energia elétrica é um bem muito valioso").

Para justificar a ideia de "tolerância semântica", os autores citam o filósofo Michael Dummett e seu artigo "Wang's Paradox" (1975). Nesse artigo, Dummett defende que, a depender do contexto, algumas palavras ou expressões são mais vagas que outras. Um dos exemplos que ele utiliza é a palavra "adulto", que pode, em um contexto jurídico, ter um significado determinado ("aquele que tem entre 30 e 59 anos", segundo o direito brasileiro ${ }^{51}$ ), mas ter um significado mais amplo (ou seja, vago) em outro contexto. Em um contexto familiar, como na relação entre pais e filhos, é impossível determinar o momento exato em que, para os pais, os filhos deixam de ser adolescentes para se tornarem adultos.

Assim, afirmam Canele e Tuzet, a "tolerância semântica" depende do contexto; a depender do contexto, uma palavra ou expressão pode ser mais tolerante quanto às suas condições de aplicação. E, além disso, a "tolerância semântica" também é uma questão de grau: se, à luz do contexto, o caso for ligeiramente diferente do padrão, haverá tolerância quanto às suas condições de aplicação; mas, se a diferença ao padrão for contextualmente relevante, não haverá tolerância - ou seja, os termos não se aplicarão.

Tal concepção - a de que a tolerância semântica é uma questão de grau e depende do contexto - se baseia no "Princípio da Tolerância" (formulado por Steward Shapiro no livro "Vagueness in Context"): "Suponha que dois objetos $a$, a' no campo $P$ difiram apenas marginalmente no aspecto relevante (no qual $P$ é tolerante). Então, se alguém julga competentemente a como tendo $P$, então não pode julgar competentemente a' de qualquer outra maneira" (SHAPIRO, 2006, p. 8).

\footnotetext{
${ }^{51}$ Não há, no direito brasileiro, uma lei que expressamente defina o conceito de "adulto". Mas há o Estatuto da Juventude (Lei n. ${ }^{\circ}$ 12.852/2013) e o Estatuto do Idoso (Lei n. $\left.{ }^{\circ} 10.741 / 2003\right)$. O primeiro define os jovens, no parágrafo primeiro do artigo $1^{\circ}$, como as pessoas com idade entre 15 e 29 anos de idade; o segundo define o idoso, em seu artigo $1^{\circ}$, como a pessoa com idade igual ou superior a 60 anos.
} 
Para Canele e Tuzet (2014, p. 238), o "Princípio da Tolerância" pode fornecer o critério necessário para determinar se o caso em questão está inserido no campo B ou C:

O princípio da tolerância estabelece as condições sob as quais se justifica a extensão de um regulamento a um caso limítrofe. Essas condições dependem das características do objeto da regulamentação que são consideradas relevantes, dentro de um determinado contexto, quanto às condições de aplicação de um determinado termo legal.

Ao ler tal sugestão, automaticamente surge uma dúvida, que os autores reconhecem: Quais seriam as características relevantes?

Os autores reconhecem essa dúvida na tentativa de se antecipar a ela. Para eles, as características não são determinadas pelo significado padrão de um termo "vago", mas sim pelo contexto. "Restrições contextuais impostas aos usos da linguagem determinam quais características de um determinado caso são relevantes na adjudicação" (CANALE e TUZET, 2014, p. 238). E afirmam, ainda, que tais restrições são, em geral, explicitadas através dos argumentos jurídicos utilizados. Os diversos argumentos que o jurista tem a sua disposição (argumenta da interpretação história, argumento da interpretação evolutiva, argumento da harmonização contextual, argumenta da coerência, etc. ${ }^{52}$ ) acabam por realçar as restrições contextuais que o jurista está levando em consideração ao interpretar determina norma jurídica.

Portanto, quando um juiz interpreta a palavra "coisas" de forma a incluir - estendendo seu significado padrão - as ondas eletromagnéticas, ele terá que justificar essa interpretação extensiva; e, ao argumentar a favor da interpretação extensiva, ele irá realçar as características relevantes. Como julgar se tais características são relevantes ou não? Através da prática argumentativa; através dos participantes dessa prática e daquilo que é aceito por eles. "O processo argumentativo visa determinar o conteúdo semântico de um termo vago em um caso limítrofe

52 Sobre os diferentes tipos de argumentos, ver SGARBI, 2007, p. 525-566. 
com base nas restrições contextuais explicitadas nos argumentos jurídicos" (CANALE e TUZET, 2013, p. 238). Se a extensão for aceita pelos participantes do processo argumentativo, de acordo com os padrões argumentativos aceitos, então a palavra "coisas" também irá englobar as ondas eletromagnéticas (pois, a partir do momento em que o argumento foi aceito, reconhece-se, automaticamente, o compartilhamento das características relevantes).

Segundo os autores, o mesmo não ocorre com a analogia. Nela, o ponto de partida do intérprete é a constatação da lacuna - ou seja, a constatação de que o caso em questão não é regulado pela norma jurídica. "A analogia pressupõe que a intepretação extensiva falhou: a analogia é o remédio para a falta de sucesso do esforço interpretativo" (CANALE e TUZET, 2014, p. 238).

Dessa forma, os autores concluem o artigo afirmando que, com base na estrutura proposta, é possível "avaliar criticamente a justificativa fornecida pela Corte de Cassação italiana no caso da Rádio do Vaticano", alegando que a Corte "não forneceu elementos suficientes para justificar sua decisão", em especial no tocante à qualificação do termo "emissão de ondas" como um ato de "arremesso" - qualificação essa que, segundo eles, é "altamente questionável" (2014, p. 240). A Corte sustentou que o termo "arremessar" não é vago, mas sim geral: dada a sua extensão semântica altamente inclusiva, a emissão de ondas magnéticas advindas do Vaticano está entre os significados possíveis de "arremesso". E, para justificar essa afirmação, a Corte cita os usos poéticos do termo conforme os versos de Dante Alighieri. Mas Damiano Canale e Giovanni Tuzet argumentam que, "não obstante a grandeza de Dante e seu domínio majestoso da língua italiana", o uso poético/metafórico do termo não é suficiente para justificar a sua extensão na linguagem comum - e que, além disso, o termo "arremesso" não é tão geral quanto assumido pela Corte. Por fim, concluem: é possível suspeitar que tal decisão viola gravemente o Estado de Direito e o princípio da legalidade no direito penal. 
Entretanto, não podemos deixar de notar que a estrutura proposta por Damiano Canale e Giovanni Tuzet está longe de solucionar os problemas que rodeiam a distinção entre analogia e interpretação extensiva. Os próprios apresentam o diagnóstico - a falta de métodos, critérios ou orientações seguras para distinguir uma técnica da outra -, mas a cura proposta - "tolerância semântica" e justificação da extensão através da prática argumentativa (pela aceitação dos participantes do processo argumentativo - está longe de oferecer qualquer segurança. $E$, mesmo utilizando o interessante "Esquema da vagueza" para explicar os desafios impostos pela textura aberta da linguagem, eles não conseguem explicar como podemos determinar as fronteiras entre os conjuntos $A, B$ e C.

A "tolerância semântica" e o recurso à aceitação da prática argumentativa são insuficientes enquanto tentativa de oferecer um terreno seguro para aqueles que buscam compreender se uma decisão foi o resultado de uma interpretação extensiva ou de uma extensão (não declarada) por analogia. Os próprios reconhecem, em uma nota de rodapé (2014, p. 237), que a estrutura por eles proposta pode ser contestada pela teoria epistêmica da vagueza elaborada pelo filósofo Timothy Williamson. Para Williamson, "a vagueza é um tipo de ignorância" (1992, p. 145). Ou seja, a vagueza não é uma propriedade da linguagem ou da semântica nem uma propriedade do mundo - ela é uma propriedade de nós mesmos (FARIA, 2013, p. 2). Nesse sentido, a vagueza é uma consequência da nossa própria ignorância e das limitações epistêmicas. Como afirma Domingos Faria, "nos predicados vagos o nosso mecanismo cognitivo é insuficiente para conhecermos onde está a fronteira. Ou seja, somos ignorantes sobre onde reside a fronteira" (FARIA, 2013, p. 2).

Se não sabemos aonde reside a fronteira, como avaliar o uso da analogia ou da interpretação extensiva? Como saber quando uma termina e a outra começa? E, além disso, diante da impossibilidade de respondermos (com um mínimo de segurança e previsibilidade) tais questões, um problema gravíssimo também fica sem resposta: o que impedirá o uso estratégico de ambas as técnicas por parte do juiz? 
Quem aponta esse problema são os próprios Damiano Canale e Giovanni Tuzet (2014, p. 228):

\begin{abstract}
A analogia e a interpretação extensiva chegam ao mesmo resultado a partir dos mesmos materiais jurídicos: ambos justificam a extensão de um regulamento a um caso que não é explicitamente considerado pela lei. Como consequência, pode-se suspeitar que os juízes usam estrategicamente esses cânones de argumentação. Quando um juiz pretende, por qualquer motivo, punir uma conduta que não é explicitamente regulada por uma disposição penal, então ela justifica sua decisão como o resultado convincente uma interpretação extensiva. Do contrário, quando um juiz não está disposto a punir a mesma conduta, alega que a extensão da responsabilidade criminal não é permitida, pois se trataria de um caso de analogia. Como resultado, esses cânones de tomada de decisão seriam suscetíveis de qualquer manipulação para fins de proteção e controle social.
\end{abstract}

Essa suspeita está longe de ser infundada. No Brasil, podemos observa-la em na recente decisão do Supremo Tribunal Federal que enquadrou a homofobia e a transfobia como crimes de racismo.

\title{
7.2
}

Uso estratégico na Ação Direta de Inconstitucionalidade por Omissão 26 e no Mandado de Injunção 4733

Uma pequena amostra de um contexto atroz: Em 2009, um grupo neonazista que pratica crimes contra homossexuais jogou uma bomba no meio da multidão que participava da Parada LGBT em São Paulo; a explosão deixou 14 feridos (RIBEIRO, 2009). No ano seguinte, um grupo de cinco pessoas agrediu um jovem por ter sido presumido como homossexual; eles utilizaram lâmpadas fluorescentes como bastões durante o ataque (MACEDO, 2010). Em São João da Boa Vista, no interior de São Paulo, durante uma exposição agropecuária, pai e filho foram agredidos depois de terem se abraçado em público - os agressores 
acharam se tratar de um casal homossexual; o pai teve a orelha decepada durante o ataque (CARDILI, 2011). "Eles começaram a provocar, chamar de viado e dizer que não merecíamos viver", disse um homem que foi agredido após sair de uma boate com o namorado; ele teve o pé quebrado (ORRICO, 2011). Como consequência dessas atrocidades, o número de brasileiros que vivem no exterior e pedem asilo alegando homofobia só aumenta. "Não volto de jeito nenhum; aqui [Canadá] sou um ser humano, não uma condição", disse um brasileiro em entrevista para o portal UOL (GARCIA, 2012).

Essa pequena amostra compõe um quadro medonho da atual sociedade brasileira: um quadro em que a homofobia e a transfobia atingem limites que ferem não somente os valores protegidos pela Constituição, mas os valores básicos da dignidade e decência.

No ano de 2010, um homossexual brasileiro foi morto a cada um dia e meio; foram 260 gays, travestis e lésbicas assassinados no Brasil números que representam um enorme aumento em relação aos últimos cinco anos: entre 2005 e 2010 houve um aumento de 113\% no número de assassinatos de homossexuais (JINKINGS, 2011).

As notícias acima datam dos anos 2009/2012; mas a realidade que elas apresentam não diminuiu nos anos seguintes. Pelo contrário: em 2018, a ONG "Transgender Europe" elaborou um relatório apontando que, entre os anos de 2008 e 2016, 868 transexuais foram assassinados no Brasil. Esse número coloca o Brasil em primeiro lugar na lista dos países aonde mais transexuais são mortos; o México ocupa o segundo lugar dessa lista, com um número de homicídios três vezes menor (MORENO, 2018).

E esses dados levam em consideração somente os casos que foram notificados. Quando se trata de grupos alijados como os homossexuais e os transexuais, a subnotificação é uma hipótese altamente razoável. Conforme Diego Bacha Silva e Alexandre Gustavo Bahia, há, no Brasil, uma subnotificação de dados de violência de violência transfóbica decorrente: 
"(a) da situação de marginalidade social, econômica e de assistência jurídica especializada de boa parte da minoria LGBT, (b) da descaracterização formal, em muitos casos, da natureza homotransfóbica específica do evento quando a denúncia é feita e, outrossim, (c) decorrente da expectativa de que, mesmo havendo notificação, o(s) agressor(es) não será(ão) punido(s)" (SILVA e BAHIA, 2015, p. 184).

Há motivos, portanto, para acreditar que esse quadro atroz é ainda pior (como se isso ainda fosse possível...).

Esse é o contexto social que o Supremo Tribunal Federal tinha diante de si quando do julgamento da Ação Direta de Inconstitucionalidade por Omissão 26 e do Mandado de Injunção 4733. Elas foram ajuizadas no ano de 2012 pelo Partido Popular Socialista PPS e pela Associação Brasileira de Gays, Lésbicas, Travestis e Transexuais - ABGLT, respectivamente. Os pedidos: a declaração da mora inconstitucional do Congresso Nacional na criminalização específica da homofobia e da transfobia e o reconhecimento da homofobia e transfobia no conceito ontológico-constitucional de racismo. Em linhas gerais, os requerentes buscam a criminalização da homofobia e da transfobia. (Ao comentar uma das notícias citadas acima, a jurista Maria Berenice Dias disse a raiz para esse quadro tradicional de segregação e de não reconhecimento de orientações sexuais e identidades de gênero minoritárias está na não criminalização da homofobia e da transfobia no Brasil (GARCIA, 2012).)

Apesar do contexto atroz de preconceito e discriminação que existe na sociedade brasileira, não há lei que expressamente tipifique a homofobia e a transfobia como crime. A Lei do Crime Racial ( $n .^{\circ} 7.716$ ) data do ano de 1989. Mas ela não dispõe especificamente sobre a homofobia e a transfobia; conforme prevê o artigo $1^{\circ}$, "serão punidos, na forma desta Lei, os crimes resultantes de discriminação ou preconceito de raça, cor, etnia, religião ou procedência nacional". Até existe proposta legislativa tendente a criminalizar a homofobia e a transfobia, mas ela foi apresentada na Câmara dos Deputados em 2001 e está, desde 2006, em 
deliberação no Senado Federal - uma omissão legislativa que desafia o que se entende por razoável. ${ }^{53}$

$E$, além do problema da omissão legislativa, há o problema em relação ao significado jurídico da palavra "racismo". O artigo $5^{\circ}$, XLII da Constituição Federal dispõe que "a prática do racismo constitui crime inafiançável e imprescritível, sujeito à pena de reclusão, nos termos da lei". Nesse dispositivo, a palavra "racismo" deve ser entendida como o conjunto de teorias e crenças que estabelecem uma hierarquia entre raças ou etnias, ou o seu significado é mais amplo do que aquele posto pelos dicionários?

Na falta de uma lei específica, o enquadramento da homofobia e da transfobia no conceito de racismo pode ajudar a reverter o preconceito e a discriminação que existe na sociedade brasileira. A Lei do Crime Racial proíbe uma série de condutas - recusar ou impedir acesso a estabelecimento comercial, negando-se a servir, atender ou receber o cliente ou comprador (art. $5^{\circ}$ ); recusar, negar ou impedir a inscrição ou ingresso de aluno em estabelecimento de ensino público ou privado de qualquer grau (art. $6^{\circ}$ ); impedir o acesso ou recusar hospedagem em hotel, pensão, estalagem ou qualquer estabelecimento similar (art. $7^{\circ}$ ); impedir o acesso ou recusar atendimento em restaurantes, bares, confeitarias, ou locais semelhantes abertos ao público (art. $8^{\circ}$ ) -, e sua aplicabilidade para os casos de homofobia e transfobia pode ser um primeiro passo na tentativa de reverter o quadro atroz vivenciado.

53 Conforme a jurisprudência do Supremo Tribunal Federal, não é qualquer omissão legislativa que dá ensejo a uma declaração de inconstitucionalidade. Para que isso ocorra, a omissão deve ser "desarrazoada". Se o legislativo está omisso por, digamos, uma semana, essa omissão é razoável - afinal, o processo legislativo é complexo, composto de inúmeros procedimentos, e deve ser dado ao parlamento o tempo necessário para deliberar sobre os projetos de lei. Por outro lado, se o legislativo está omisso por trinta anos, essa omissão ultrapassa o razoável - não há tema, por mais complexo que seja, que precisa de mais de trinta de deliberação. Mas uma semana e trinta anos são dois extremos; a grande questão está no meio: a partir de quando tempo uma omissão passa do razoável e entra no campo do que é desarrazoado? Não há resposta objetiva. A questão deverá ser analisada caso a caso (pelo Supremo Tribunal Federal). $\mathrm{O}$ máximo que a corte estabeleceu em sua jurisprudência foi esse princípio vago: para dar ensejo a uma declaração de inconstitucionalidade, a omissão deve ser "desarrazoada" (MENDES, 2012, p. 473,475). 
Para tanto, os requerentes defendem que a homofobia e a transfobia constituem espécies do gênero racismo. Para justificar essa defesa, utilizam uma argumentação por analogia: se o racismo é toda ideologia que prega a superioridade/inferioridade de um grupo relativamente a outro; e se a homofobia e a transfobia implicam na inferiorização da população LGBT em relação às pessoas cisgêneras; logo, não há porque não se falar em racismo homofóbico e transfóbico.

O Supremo Tribunal Federal terminou o julgamento da ADO 26 e do Ml 4.733 no dia 13 de junho de 2019, firmando três teses. Para os fins da presente pesquisa, somente as teses 1 e 3 merecem destaque. Vejamos a primeira:

1. Até que sobrevenha lei emanada do Congresso Nacional destinada a implementar os mandados de criminalização definidos nos incisos XLI e XLII do art. $5^{\circ}$ da Constituição da República, as condutas homofóbicas e transfóbicas, reais ou supostas, que envolvam aversão odiosa à orientação sexual ou à identidade de gênero de alguém, por traduzirem expressões de racismo, compreendido este em sua dimensão social, ajustam-se, por identidade de razão e mediante adequação típica, aos preceitos primários de incriminação definidos na Lei n. ${ }^{\circ}$ 7.716, de 08/01/1989, constituindo, também, na hipótese de homicídio doloso, circunstância que o qualifica, por configurar motivo torpe (Código Penal, art. $121, \S 2^{\circ}$, I, "in fine").

Como é possível observar, o STF reconheceu a omissão legislativa no tocante à criminalização da homofobia e da transfobia - e, até que o Congresso Nacional aprove lei criminalizando as condutas de homofobia e transfobia, tais condutas serão enquadradas na lei de racismo. Uma decisão condizente com a aplicação da analogia.

O problema reside no fato do direito penal não aceitar a aplicação da analogia quando em prejuízo do réu. Como, então, justificar o uso da analogia? Através de uma ampliação do conceito de racismo, conforme se observa na terceira tese firmada.

3. O conceito de racismo, compreendido em sua dimensão social, projeta-se para além de aspectos estritamente biológicos ou fenotípicos, pois resulta, enquanto manifestação de poder, de uma construção de índole histórico-cultural motivada pelo objetivo de justificar a desigualdade e destinada ao controle 
ideológico, à dominação política, à subjugação social e à negação da alteridade, da dignidade e da humanidade daqueles que, por integraram grupo vulnerável (LGBTI+) e por não pertencerem ao estamento que detém posição de hegemonia em uma dada estrutura social, são considerados estranhos e diferentes, degradados à condição de marginais do ordenamento jurídico, expostos, em consequência de odiosa inferiorização e de perversa estigmatização, a uma injusta e lesiva situação de exclusão do sistema geral de proteção do direito.

Uma decisão, no mínimo, estranha: o STF, mesmo reconhecendo a existência de uma lacuna jurídica, afirmou que as condutas homofóbicas ou transfóbicas estão inseridas no conceito de racismo. A decisão é estranha porque, das duas, uma: ou o STF reconhece a lacuna jurídica e fixa prazo para o Congresso Nacional editar lei; ou o STF decide que não há lacuna, porque a Lei de Racismo já está apta a combater a homofobia e a transfobia.

\section{3}

\section{Analogia ou interpretação extensiva?}

Uso estratégico; uma distinção que pode ser facilmente desvirtuada; uma linha limítrofe fluida; algumas semelhanças. Ao fim, as diferenças que usualmente são apontadas para separar a analogia da interpretação extensiva conseguem justificar a manutenção dessa distinção? Não, pois também é possível apontar fragilidades nesses traços diferenciadores.

Como vimos, as principais diferenças podem ser resumidas em dois pontos: (i) A aplicação da analogia pressupõe a existência de uma lacuna jurídica, enquanto na interpretação extensiva ocorre exatamente o contrário (existe norma jurídica reguladora, mas ela terá o seu campo semântico expandido). (ii) Consequentemente, na analogia, há a criação 
de uma nova norma, enquanto na interpretação extensiva aplica uma norma jurídica já existente, decidindo sobre o seu significado.

Quanto ao primeiro ponto, não poderíamos objetar que ambas pressupõem a existência de uma lacuna jurídica? Conforme visto no segundo capítulo desta tese, a existência de uma lacuna jurídica é tida como um pressuposto para a aplicação da analogia. Mas, quando o jurista faz uso da interpretação extensiva, ele não está também diante de uma lacuna jurídica? Tanto a analogia quanto a interpretação extensiva são técnicas utilizadas pelo jurista quando o caso em questão não é explicitamente regulado pelo direito, pois, se o caso é explicitamente regulado pelo direito, basta uma subsunção da norma ao caso. $E$, partindo do conceito neutro de lacuna jurídica adotado por Fábio Shecaira e Noel Struchiner (2016, p. 103-104) - utilizada para se referir a situações em que o texto legal não regula claramente algum tipo de conduta -, podemos afirmar que o pressuposto da existência da lacuna jurídica não é exclusividade da analogia.

Quanto ao segundo ponto, não poderíamos objetar que a criação de uma nova norma é o resultado final tanto da analogia quanto da interpretação extensiva? Conforme demonstramos, o que justifica a proximidade (e, consequentemente, as confusões) entre a analogia e a interpretação extensiva é o raciocínio analógico; o processo cognitivo empregado em ambas é o mesmo. Nesse sentido, conforme aponta o Riccardo Guastini (2018, p. 278), "não se vê o que mais pode justificar uma interpretação extensiva (...) senão um juízo de semelhança entre os casos marginais, ou duvidosos, e aqueles incluídos literalmente no âmbito de aplicação da norma". Seja lá sob qual alcunha o jurista esteja atuando - analogia ou interpretação extensiva -, ele procederá buscando semelhanças entre o caso regulado (origem) e o caso não regulado (alvo) que justifiquem a ampliação do alcance normativo de uma norma jurídica. Similaridade e diferenças - são essas as pedras angulares de toda argumentação que justifica determinada interpretação (GUASTINI, 2018, p. 278). Entendendo, portanto, que a interpretação extensiva pode ser configurada como uma forma de criação judicial, podemos afirmar que essa característica não é exclusiva da analogia. 
Do exposto, a analogia e a interpretação extensiva podem ser vistas como modos distintos para o mesmo tipo de argumentação. O que é muito pouco para justificar a distinção. Ambas chegam ao mesmo resultado. Como no exemplo fornecido por Riccardo Guastini (2018, p. 278): uma norma jurídica que regulamenta as religiões pode ser utilizada para regular o movimento New Age? Ou se entende que tal movimento, apesar de não incluído no conceito de religião, é parecido com uma, ou se entende que o movimento New Age é considerado como religião. Duas possibilidades argumentativas, o mesmo resultado.

O que sobra ao final? Mais semelhanças do que diferenças.

O ruído é total. 


\section{8}

\section{Conclusão: silêncio?}

Para o jurista italiano Riccardo Guastini (2018, p. 274-279), é possível visualizar duas respostas para a pergunta "a analogia se diferencia ou não da interpretação analógica"?

A primeira afirma que sim - analogia e interpretação extensiva são fenômenos distintos. A interpretação extensiva é uma operação genuinamente interpretativa; ela amplia o campo semântico de uma norma jurídica para além daquilo que está literalmente expresso. Já a analogia envolve um ato de criação normativa; como o seu pressuposto é a existência de uma lacuna jurídica, ela irá atribuir a um caso não regulamentado pelo direito a mesma disciplina conferida a um caso semelhante já regulamentado.

A segunda sustenta que não - apesar de algumas diferenças conceituais, os resultados alcançados por ambas são idênticos. Tanto a analogia quanto a interpretação extensiva são utilizadas para solucionar casos que não são explicitamente regulados pelo direito. Ambas "vinculam uma consequência jurídica a um caso que não se enquadra no significado literal (ou comumente aceito) da disposição em questão" (GUASTINI, 2018, p. 274-279). Nesse sentido, analogia e interpretação extensiva são modos distintos para argumentar a mesma operação.

A presente tese se alinha à segunda resposta. Entre a analogia e a interpretação extensiva existem mais semelhanças que diferenças. Além das semelhanças apontadas no parágrafo anterior, as recentes contribuições das ciências cognitivas possibilitam a compreensão de que 
o processo cognitivo utilizado pelo jurista é o mesmo na analogia e na interpretação extensiva. Em ambas o raciocínio analógico se faz presente. No raciocínio analógico, há o caso fonte e o caso alvo, e julgamos ambos como semelhantes quando percebemos a existência de características comuns. Esse tipo de raciocínio sempre esteve presente nas explicações que a teoria do direito fornece no tocante à analogia; ele está presente no próprio esquema da argumentação. Mas o mesmo tipo de raciocínio também é utilizado na interpretação extensiva. Apesar de várias explicações realçarem somente o aspecto da semântica envolvida na operação, a busca por semelhanças exerce um papel importante. O que justifica a interpretação extensiva é o juízo de semelhança entre casos claramente inseridos no âmbito de atuação da norma jurídica e os casos duvidosos. É essa constatação - de que o raciocínio analógico está presente tanto na analogia e na interpretação extensiva - que explica as constantes confusões que permeiam algumas discussões teóricos sobre ambas as técnicas (como no uso do termo "interpretação extensiva por analogia").

$E$, quanto às distinções que usualmente são apontadas, elas não se sustentam. Em primeiro lugar, a existência de uma lacuna jurídica não é um pressuposto exclusivo da analogia; ela também está presente na utilização da interpretação extensiva. Em todos os exemplos que podem ser utilizados para se referir a uma ou outra, o jurista está diante de uma situação em que o texto legal não regula claramente algum tipo de conduta. Em segundo lugar, o ato criativo não é uma consequência exclusiva da analogia; ela também está presente na utilização da interpretação extensiva. Um juízo de semelhança é um elemento fundamental em toda justificação de uma interpretação extensiva - e a constatação, comprovada pelas ciências cognitivas, de que realizamos tais juízos com base em semelhanças meramente superficiais é mais um fator a sustentar a impossibilidade de se estabelecer, de forma objetiva, a fronteira entre a zona de certeza e a zona de penumbra. O argumento analógico é usualmente acusado de ser uma forma de argumentação que carece de força, e não há razão para tal acusação não ser direcionada também para a interpretação extensiva. 
A presente tese começou instigada por um ruído: talvez a analogia e a interpretação extensiva não sejam tão diferentes assim. E termina com silêncio? Longe disso. O ruído ainda se faz presente, mais alto que nunca. E isso não é ruim. Conforme dito na introdução, se essa tese conseguir chamar a atenção da teoria do direito brasileira para o tema da analogia e da interpretação extensiva, se ela conseguir mostrar o quanto o tema é rico e instigante, terá cumprido o seu papel.

Como na frase do compositor John Cage (2011, p. 3) escolhida como epígrafe: "Não importa onde estejamos, a maior parte do que ouvimos é ruído. Quando ignoramos, nos perturba. Quanto escutamos com atenção, ficamos fascinados". 
9

Referências Bibliográficas

ALCHOURRÓN, Carlos Eduardo; BULYGIN, Eugenio. Sistemas normativos: introducción a la metodologia de las ciencias jurídicas. Buenos Aires: Astrea, 2015.

ALEXANDER, Larry; SHERWIN, Emily. Desmystifying Legal Reasoning. Cambridge: Cambridge University Press, 2008.

ANDERSON, John. The adaptive nature of human categorization. PSYCHOLOGICAL REVIEW, vol. 98, 1991, p. 409-429.

ARIELY, Dan. Predictably Irrational: The Hidden Forces That Shape Our Decisions. Nova York: Harper Perennial, 2010.

ARISTÓTELES. Metafísica. Porto Alegre: Globo, 1969.

ÁVILA, Humberto. Argumentação jurídica e a imunidade do livro eletrônico. In: REVISTA DA FACULDADE DE DIREITO DA UFRGS, vol. 19, 2001, p. 157-180.

ÁVILA, Humberto. Teoria dos princípios - da definição à aplicação dos princípios jurídicos. São Paulo: Malheiros, 2005. 
BARTHA, Paul. By Parallel Reasoning - The Construction and Evaluation of Analogical Arguments. Oxford: Oxford University Press, 2010.

BARTHA, Paul. Analogy and Analogical Reasoning. In: STANFORD ENCYCLOPEDIA OF PHILOSOPHY, 2013. Disponível em: https://goo.gl/hYms1M. Acesso em: 05 dez. 2020.

BERMEJO-LUQUE, Lilian. The Uses of Analogies. In: RIBEIRO, Henrique Jales (ed.). SYSTEMATIC APPROACHES TO ARGUMENT BY ANALOGY. Springer, 2014, p. 57-72.

BITENCOURT, Cezar Roberto. Tratado de direito penal - vol. 1: parte geral. São Paulo: Saraiva, 2008.

BOBBIO, Norberto. Teoria do ordenamento jurídico. Brasília: UNB, 1995.

BROWN, William R. Two Traditions of Analogy. In: INFORMAL LOGIC, vol. 11, n. $^{\circ} 3,1989$, p. 161-172.

CAGE, John. Silence: Lectures and Writings. Connecticut: Wesleyan University Press, 2011.

CANALE, Damiano; TUZET, Giovanni. Analogy and Interpretation in Legal Argumentation. In: RIBEIRO, Henrique Jales (ed.). SYSTEMATIC APPROACHES TO ARGUMENT BY ANALOGY. Berlim: Springer, 2014, p. 227-242.

CANALE, Damiano; TUZET, Giovanni. What is the Reason for this Rule? An Inferential Account of the Ratio Legis. In: ARGUMENTATION, vol. 24, 2010, p. 197-210.

CANALE, Damiano; TUZET, Giovanni. Analogical reasoning and extensive interpretation. In: KAPEIN, Hendrik; VELDEN, Bastian van der (eds.). ANALOGY AND EXEMPLARY REASONING IN LEGAL DISCOURSE. Amsterdam: Amsterdam University Press, 2018, p. 65-86. 
CAÑIZARES, Enrique Roldán. Luis Jiménez de Asúa - derecho penal, república, exílio. Madrid: Dykinson, 2019.

CARDILI, Juliane. 'Não pode nem abraçar o filho', diz homem que teve orelha cortada. G1 SP, 19 jul. 2011. Disponível em: https://glo.bo/2vmcY54. Acesso em: 05 dez. 2020.

CASTANHEIRA NEVES, Antonio. O princípio da legalidade criminal: o seu problema jurídico e seu critério dogmático. In: DIGESTA ESCRITOS ACERCA DO DIREITO, DO PENSAMENTO JURÍDICO, DA SUA METODOLOGIA E OUTROS, vol. 1. Coimbra: Coimbra editora, 1995.

DIMOULIS, Dimitri. Manual de introdução ao estudo do direito. São Paulo: Revista dos Tribunais, 2011.

DINIZ, Maria Helena Diniz. Lei de introdução ao código civil brasileiro interpretada. São Paulo: Saraiva, 1996.

DUMMETT, Michael. Frege: Philosophy of Language. Londres: Harper \& Row, 1973.

DUMMETT, Michael. Wang's Paradox. SYNTHESE, vol. 30, 1975, p. 301-324.

EARP, Brian; EVERETT, Jim; MADVA, Elizabeth; HAMLIN, Kiley. Out, Dammed Spot: Can the "Macbeth Effect" be replicated? In: BASIC ANS APPLIED SOCIAL PSYCHOLOGY, vol. 36, n. 1, 2014, p. 91-98.

EASWARAN, Kenny. Review of "By Parallel Reasoning: The Construction and Evaluation of Analogical Arguments". NOTRE DAME PHILOSOPHICAL REVIEWS, 10 jun. 2011. Disponível em: https://bit.ly/2NiGrSN. Acesso em: 05 dez. 2020.

EISENBERG, Melvin Aron. The Nature of the Commom Law. Cambridge: Harvard University Press, 1988. 
ENDICOTT, Timothy. Vagueness in Law. Oxford: Oxford University Press, 2000.

ENGISCH, Karl. Introdução ao pensamento jurídico. Lisboa: Fundação Calouste Gulbenkian, 1996.

FARIA, Domingos. Como explicar o fenómeno da vagueza? In: INVESTIGAÇÕES FILOSÓFICAS, vol. 4, n. 1, 2013, p. 1-8.

FAUCONNIER, Gilles; TURNER, Mark. The Way We Think: Conceptual Blending and the Mind's Hidden Complexities. Nova lorque: Basic Books, 2002.

FAYARD, Jennifer; BASSI, Amandeep; BERNSTEIN, Daniel; ROBERTS, Brent. Is cleanliness next to godliness? Dispelling old wives' tales: Failure to replicate Zhong and Liljenquist (2006). In: Journal of Articles in Support of the Null Hypothesis, vol. 06, n. 02, 2009, p. 21-30.

FERRAZ Jr., Tercio Sampaio. Introdução ao estudo do direito: técnica, decisão, dominação. São Paulo: Atlas, 2007.

FREITAS, Juarez. Interpretação sistemática do direito em face das antinomias normativas, axiológicas e principiológicas. Tese de doutorado apresentada ao programa de pós-graduação em Direito da Universidade Federal de Santa Catarina, 1994.

GAIMAN, Neil. O oceano no fim do caminho. São Paulo: Intrínseca, 2013.

GARCIA, Janaína. Cresce número de brasileiros gays no exterior que pedem asilo alegando homofobia. UOL, 04 abr. 2012. Disponível em: https://bit.ly/3cm1UFs. Acesso em: 05 dez. 2020.

GENTNER, Dedre. The Mechanisms of Analogical Learning. In: VOSNIADOU, Stella; ORTONY, Andrew (eds.). SIMILARITY AND ANALOGICAL LEARNING. Nova York: Cambridge University Press, 1989, p. 199-241. 
GENTNER, Dedre; RATTERMANN, Mary Jo. Language and the career of similarity. In: GELMAN, Susan; BYRNES, James (eds.). PERSPECTIVES ON LANGUAGE AND THOUGHT - INTERRELATIONS IN DEVELOPMENT. Cambridge: Cambridge University Press, 1991.

GENTNER, Dedre. Why we're so smart. In: GENTNER, Dedre; GOLDINMEADOW, Susan (eds.). LANGUAGE IN MIND: ADVANCES IN THE STUDY OF LANGUAGE AND THOUGHT. Cambridge: MIT Press, 2003, p. $195-235$.

GILOVICH, Thomas. Seeing the past in the present: The effect of associations to familiar events on judgments and decisions. JOURNAL OF PERSONALITY AND SOCIAL PSYCHOLOGY, n. ${ }^{\circ}$ 40, 1981, p. 797-808.

GLADWELL, Malcolm. Fora de Série - Outliers. Rio de Janeiro: Sextante, 2011.

ámGOVIER, Trudy. Should a priori Analogies be Regarded as Deductive Arguments? In: INFORMAL LOGIC, vol. 22, n. ${ }^{\circ} 2,2002$, p. 155-157.

GREEN, Henry. Caught, Back, Concluding. Londres: Vintage Classics, 2016.

GRICE, Paul. Logic and Conversation. In: STUDIES IN THE WAY OF WORDS. Cambridge: Harvard University Press, 1989a., p. 22-40.

GRICE, Paul. Meaning. In: STUDIES IN THE WAY OF WORDS. Cambridge: Harvard University Press, 1989b., p. 213-223.

GRICE, Paul. Postwar Oxford Philosophy. In: STUDIES IN THE WAY OF WORDS. Cambridge: Harvard University Press, 1989c, p. 171-180.

GUARINI, Marcello. A Defence of Non-deductive Reconstructions of Analogical Arguments. In: INFORMAL LOGIC, vol. 24, n. ${ }^{\circ} 2,2004$, p. 153-168. 
GUASTINI, Riccardo. Interpretar y argumentar. Madrid: Centro de Estudios Políticos y Constitucionales, 2014.

GUASTINI, Riccardo. La interpretación de los documentos normativos. Ciudad Satélite: Derecho Global editores, 2018.

HART, Herbert A. L. O conceito de direito. São Paulo: Martins Fontes, 2009.

HOBBES, Thomas. Leviatã: ou a matéria, forma e poder de uma república eclesiástica e civil. São Paulo: Martins Fontes, 2019.

HOFSTADTER, Douglas. Gödel, Escher, Bach: an Eternal Golden Braid. Nova lorque: Basic Books, 1979.

HOFSTADTER, Douglas. Prologue: The Why, the When, the Where, and the Who of This Book. In: FLUID CONCEPTS AND CREATIVE ANALOGIES - COMPUTER MODELS OF THE FUNDAMENTAL MECHANISMS OF THOUGHT. Nova lorque: Basic Books, 1995a, p. 1-12.

HOFSTADTER, Douglas. The Ineradicable Eliza Effect and Its Dangers. In: FLUID CONCEPTS AND CREATIVE ANALOGIES COMPUTER MODELS OF THE FUNDAMENTAL MECHANISMS OF THOUGHT. Nova lorque: Basic Books, 1995b, p. 155-168.

HOFSTADTER, Douglas. Analogy as the Core of Cognition. In: GENTNER, Dedre; HOLYOAK, Keith; KOKINOV, Boicho (eds.). THE ANALOGICAL MIND: PERSPECTIVES FROM COGNITE SCIENCE. Cambridge: MIT Press, 2001, p. 499-538.

HOFSTADTER, Douglas; SANDER, Emmanuel. Surfaces and Essences: Analogy as the Fuel and Fire of Thinking. Nova lorque: Basic Books, 2013.

HOFSTADTER, Douglas. The Shallowness of Google Translate. THE ATLANTIC, jan., 2018. Disponível em: https://bit.ly/33oxl7Y. Acesso em: 05 dez. 2020. 
HOLYOAK, Keith; THAGARD, Paul. Mental Leaps: Analogy in Creative Thought. Massachussetts: MIT Press, 1994.

HOLYOAK, Keith. Analogy. In: HOLYOAK, Keith; MORRISON, Robert (eds.). THE CAMBRIDGE HANDBOOK OF THINKING AND REASONING. Cambridge: Cambridge University Press, 2005, p. 117-142.

ITKONEN, Esa. Analogy as Structure and Process: Approaches in linguistics, cognitive psychology and philosophy of science. Amsterdã: John Benjamins, 2005.

JAMES, Henry. Pelos olhos de Maisie. São Paulo: Companhia das Letras, 2010.

JAMES, William. The Principles of Psychology. Cambridge: Harvard University Press, 1983.

JINKINGS, Daniella. A cada 36 horas, um homossexual é morto no Brasil. AGÊNCIA BRASIL, 04 abr. 2011. Disponível em: https://bit.ly/2uHH5mX. Acesso em: 05 dez. 2020.

JOYCE, James. Ulysses. São Paulo: Companhia das Letras, 2012.

JUTHE, André. Argument by Analogy. In: ARGUMENTATION, vol. 19, 2005, p. 01-27.

JUTHE, André. Refutation by Parallel Argument. In: ARGUMENTATION, vol. 23, 2009, p. 133-169.

JUTHE, André. A Systematic Review of Classifications of Argument by Analogy. In: RIBEIRO, Henrique Jales (ed.). SYSTEMATIC APPROACHES TO ARGUMENT BY ANALOGY. Springer, 2014.

KELSEN, Hans. Teoria geral do direito e do estado. São Paulo: Martins Fontes, 2000.

KELSEN, Hans. Teoria Pura do Direito. São Paulo: Martins Fontes, 2006. 
KHONG, Yuen Foong. Analogies at War - Korea, Munich, Dien Bien Phu, and the Vietnam Decisions of 1965. Princeton: Princeton University Press, 1992.

KRAUS, Manfred. Arguments by Analogy (and What We Can Learn about Them from Aristotle). In: EEMEREN, Frans H.; GARSSEN, Bart (eds.). REFLECTIONS ON THEORETICAL ISSUES IN ARGUMENTATION THEORY. Springer, 2015, p. 171-182.

LEITE, Fábio Carvalho. Liberdade de expressão e direito à honra: novas diretrizes para um velho problema. In: CLĖVE, Clèmerson Merlin; FREIRE, Alexandre (Org.). DIREITOS FUNDAMENTAIS E JURISDIÇÃO CONSTITUCIONAL: ANÁLISE, CRÍTICA E CONTRIBUIÇÕES. São Paulo: Revista dos Tribunais, 2014, p. 395-408.

LEWIS, Michael. O projeto desfazer. Rio de Janeiro: Intrínseca, 2016.

LIMA, Renato Brasileiro de. Manual de processo penal. Salvador: Juspodivm, 2017.

LOCKE, John. Ensaio acerca do entendimento humano. São Paulo: Nova Cultural, 1999.

MACEDO, Letícia. Grupo que usou lâmpadas como bastão para agredir jovem na Paulista. G1 SP, 14 nov. 2010. Disponível em: https://glo.bo/3cjkVs9. Acesso em: 05 dez. 2020.

MACHADO, Hugo de Brito (coord.). Imunidade tributária do livro eletrônico. São Paulo: Informações Objetivas, 1998.

MAXIMILIANO, Carlos. Hermenêutica e aplicação do direito. Rio de Janeiro: Forense, 2002.

MENDES, Gilmar Ferreira. Controle Abstrato de Constitucionalidade: ADI, ADO e ADC - comentários à lei 9.868. São Paulo: Saraiva, 2012. 
MILíCIO, Gláucia. Jornal é condenado a indenizar juiz em R\$ 593 mil. CONSULTOR JURÍDICO, 26 jun. 2009. Disponível em: https://bit.ly/2Pgmkqr. Acesso em: 05 dez. 2020.

MILLER, Alexander. Filosofia da linguagem. São Paulo: Paulus, 2010.

MORENO, Sayonara. Brasil é o país que mais mata pessoas trans no mundo. BRASIL DE FATO, 30 jan. 2018. Disponível em: https://bit.ly/388WOZT. Acesso em: 05 dez. 2020.

NEWMAN, Maria; RASHBAUM, William K. Yankee Dies in Plane Crash, Official Says. THE NEW YORK TIMES, 11 out., 2006. Disponível em: https://nyti.ms/3aThLKW. Acesso em: 05 dez. 2020.

ORRICO, Alexandre. Casal gay é agredido na região da Av. Paulista, em SP. FOLHA DE SÃO PAULO, 02 out. 2011. Disponível em: https://bit.ly/39gTfm2. Acesso em: 05 dez. 2020.

ORTEGA Y GASSET, José. O que é a filosofia? São Paulo: Vide Editorial, 2016.

PACELLI, Eugênio. Curso de processo penal. São Paulo: Atlas, 2017.

PELUSO, Vinicius de Toledo Piza. Analogia e direito penal. In: REVISTA BRASILEIRA DE CIÊNCIAS CRIMINAIS. São Paulo: Revista dos Tribunais, vol. 118, 2016, p. 159-184.

PERELMAN, Chaim. Analogie et métaphore em science, poésie et philosophie. In: MEYER, Michael (ed.). RHÉTORIQUES. Bruxelas: Universidade de Bruxelas, 1989, p. 395-409.

PIERCE, Charles Sanders. How to Make Our Ideas Clear. In: POPULAR SCIENCE MONTHLY, n. 12, 1878, p. 286-302.

PLATÃO. O sofista. Brasília: UnB, 1980.

POSNER, Richard. The Problems of Jurisprudence. Cambridge: Harvard University Press, 1990. 
PRINZ, Jesse. Furnishing the Mind: Concepts and Their Perceptual Basis. Cambridge: MIT Press, 2002.

QUINE, Willard van Orman. Natural Kinds. In: ONTOLOGICAL REALITY AND OTHER ESSAYS. Nova lorque: Columbia University Press, 1969.

RAZ, Joseph. The Functions of Law. In: THE AUTHORITY OF LAW: ESSAYS ON LAW AND MORALITY. Oxford: Oxford University Press, 1979, p. 162-177.

REALE, Miguel. Lições preliminares de direito. São Paulo: Saraiva, 2003.

REGALADO, Antonio. Who Coined "Cloud Computing"? MIT TECHNOLOGY REVIEW, 31 out., 2011. Disponível em: https://bit.ly/32ZxoeN. Acesso em: 05 dez. 2020.

REGAN, Tom. III-gotten Gains. In: CAVALIERI, Paola; SINGER, Peter (eds.). THE GREAT APE PROJECT. Nova York: St. Martin's Griffin, 1993, p. 194-205.

RIBEIRO, Marcelle. Polícia de SP confirma atentado a bomba durante Parada Gay e prende sete de grupo neonazista. O GLOBO, $04 \mathrm{dez}$. 2009. Disponível em: https://glo.bo/2wYU8Bf. Acesso em: 05 dez. 2020.

ROSCH, Eleanor; MERVIS, Carolyn; GRAY, Wayne; JOHNSON, David; BOYES-BRAEM, Penny. Basic Objects in Natural Categories. COGNITIVE PSYCHOLOGY, vol. 8, 1976, p. 382-439.

ROSS, Alf. Direito e justiça. São Paulo: Edipro, 2000.

SAFIRE, William. On Language. THE NEW YORK TIMES MAGAZINE, 8 out., 2000. Disponível em: https://nyti.ms/2tVYcRy. Acesso em: 05 dez. 2020.

SANTOS, Juarez Cirino dos Santos. Direito Penal - Parte Geral. Curitiba: ICPC, 2014. 
SAPOLSKI, Robert. Behave - The Biology of Humans at Our Best and Worst. Londres: Vintage, 2017.

SCHAUER, Frederick. A Critical Guide to Vehicles in the Park. In: NEW YORK UNIVERSITY LAW REVIEW, vol. 83, 2008, p. 1109- 1134.

SCHAUER, Frederick. Thinking Like a Lawyer: A New Introduction to Legal Reasoning. Cambridge: Harvard University Press, 2009.

SCHAUER, Frederick; SPELLMAN, Barbara. Analogy, Expertise, and Experience. UNIVERSITY OF CHICAGO LAW REVIEW, Vol. 84, n. ${ }^{1}$, 2017 , p. $101-120$.

SEARLE, John. Literal Meaning. In: EXPRESSION AND MEANING STUDIES IN THE THEORY OF SPEECH ACTS. Cambridge: Cambridge University Press, 1979, p. 117-136.

SGARBI, Adrian. Teoria do direito - primeiras lições. Rio de Janeiro: Lumen Juris, 2007.

SGARBI, Adrian. Introdução à teoria do direito. São Paulo: Marcial Pons, 2013.

SGARBI, Adrian. O mundo de Kelsen. São Paulo: Marcial Pons, 2019.

SGARBI, Adrian. Curso de teoria do direito. Rio de Janeiro: Lumen Juris, 2020.

SHAPIRO, Stewart. Vagueness in Context. Oxford: Oxford University Press, 2006.

SHECAIRA, Fábio Perin. Analogical Arguments in Ethics and Law: A Defense of a Deductivist Analysis. In: INFORMAL LOGIC, vol. 33, n. ${ }^{\circ}$, 2013, p. 406-437.

SHECAIRA, Fábio Perin. A Importância da Dedução na Argumentação Jurídica. In: FORTES, Pedro; CAMPOS, Ricardo; BARBOSA, Samuel 
(ed.). TEORIAS CONTEMPORÂNEAS DO DIREITO: O DIREITO E AS INCERTEZAS NORMATIVAS. Curitiba: Juruá, 2016.

SHECAIRA, Fábio Perin; STRUCHINER, Noel. Teoria da argumentação jurídica. Rio de Janeiro: Contraponto, 2016.

SHEKESPEARE, William. Macbeth. Porto Alegre: LP\&M Pocket, 2017.

SILVA, José Afonso da. Aplicabilidade das normas constitucionais. São Paulo: Malheiros, 1998.

SILVA, Diego Bacha; BAHIA, Alexandre Gustavo Melo Franco. Necessidade de criminalizar a homofobia no Brasil: porvir democrático e inclusão das minorias. REVISTA DA FACULDADE DE DIREITO - UFPR, vol. 60, n. ${ }^{\circ}$ 2, Curitiba, 2015, p. 177-207.

SINNOT-ARMSTRONG, Walter; FOGELIN, Robert J. Understandings Arguments - An Introduction to Informal Logic. Califórnia: Wadsworth, 2010.

SKYRMS, Brian. Choice and Chance - An Introduction to Inductive Logic. Califórnia: Wadsworth, 2000.

STRUCHINER, Noel. Direito e linguagem: uma análise da textura aberta da linguagem e sua aplicação ao direito. Rio de Janeiro: Renovar, 2002.

SUNSTEIN, Cass. On Analogical Reasoning. HARVARD LAW REVIEW, vol. 106, n. ${ }^{\circ} 3,1993$, p. 741-791.

TCHEKHOV, Anton. A ilha de Sacalina. São Paulo: Todavia, 2018.

THOMSON, Judith Jarvis. A Defense of Abortion. In: PHILOSOPHY AND PUBLIC AFFAIRS, vol. 1, n. ${ }^{\circ}$ 1, 1971, p. 47-66.

TOLSTÓI, Liev. Anna Kariênina. São Paulo: Cosac Naify, 2005. 
TVERSKY, Amos. Features of Similarity. In: PREFERENCE, BELIEF, AND SIMILARITY - SELECTED WRITING. Massachusetts: MIT Press, 2004a.

TVERSKY, Amos. Studies of Similarity. In: PREFERENCE, BELIEF, AND SIMILARITY - SELECTED WRITING. Massachusetts: MIT Press, 2004b.

VIOLANTE, José Luís Mourinho dos Santos Monteiro. O Caso Ellwanger e seu impacto no direito brasileiro. Dissertação de mestrado apresentada ao programa de pós-graduação em Direito da Pontifícia Universidade Católica de São Paulo, 2010.

VYGOTSKY, Lev. Thought and Language. Cambridge: MIT Press, 1986.

WAISMANN, Friedrich. Verifiability. In: PROCEEDINGS OF THE ARISTOTELIAN SOCIETY, vol. XIX, 1945, p. 101-164.

WALLACE, David Foster. Deciderization 2007 - A Special Report. In: BOTH FLESH AND NOT: ESSAYS. Georgia: Back Bay Books, 2013.

WALLER, Bruce N. Classifying and Analyzing Analogies. INFORMAL LOGIC, vol. 21, n. ${ }^{\circ} 3,2001$, p. 199-218.

WHARTON, Tim. Paul Grice, saying and meaning. In: UCL Working Papers in Linguistics, vol. 14, 2002, p. 207-248.

WHITNEY, William Dwight. The Life and Growth of Language. Cambridge: Cambridge University Press, 2013.

WILLIAMSON, Timothy. Vagueness and Ignorance. In: PROCEEDINGS OF THE ARISTOTELIAN SOCIETY, vol. 66, 1992, p. 145-162.

WINCHESTER, Simon. The Surgeon of Crowthorne: A Tale of Murder, Madness and the Love of Words. Londres: Penguin, 1999.

WINCHESTER, Simon. The Meaning of Everything: The Story of the Oxford English Dictionary. Oxford: Oxford University Press, 2004. 
WITTGENSTEIN, Ludwig. Investigações filosóficas. Campinas: Editora da Unicamp, 2017.

WOOD, James. Como funciona a ficção? São Paulo: Cosac Naify, 2011.

WRIGHT, Georg von. Norm and action: a logical enquiry. Londres: Routledge, 1963.

WRÓBLEWSKI, Jerry. The Judicial Application of Law. Berlim: Springer, 1992.

ZHONG, Chen-Bo; LILJENQUIST, Katie. Washing Away Your Sins: Threatened Morality and Physical Cleasing. SCIENCE, vol. 313, 2006, p. $1451-1452$. 